\title{
Energy Policy Dynamics in the European Parliament and in the Lithuanian Seimas
}

\author{
Vaida Lilionyte Manthos \\ West Virginia University, vliliony@mix.wvu.edu
}

Follow this and additional works at: https://researchrepository.wvu.edu/etd

Part of the Other Political Science Commons

\section{Recommended Citation}

Manthos, Vaida Lilionyte, "Energy Policy Dynamics in the European Parliament and in the Lithuanian Seimas" (2021). Graduate Theses, Dissertations, and Problem Reports. 8290.

https://researchrepository.wvu.edu/etd/8290

This Dissertation is protected by copyright and/or related rights. It has been brought to you by the The Research Repository @ WVU with permission from the rights-holder(s). You are free to use this Dissertation in any way that is permitted by the copyright and related rights legislation that applies to your use. For other uses you must obtain permission from the rights-holder(s) directly, unless additional rights are indicated by a Creative Commons license in the record and/ or on the work itself. This Dissertation has been accepted for inclusion in WVU Graduate Theses, Dissertations, and Problem Reports collection by an authorized administrator of The Research Repository @ WVU.

For more information, please contact researchrepository@mail.wvu.edu. 


\title{
Energy Policy Dynamics in the European Parliament and in the Lithuanian Seimas
}

\author{
Vaida Lilionyte Manthos
}

Dissertation submitted to the Eberly College of Arts and Science at West Virginia University in partial fulfillment of the requirements for the degree of Doctor of Philosophy in Political Science

John Kilwein, Ph.D., Chair

Shauna Fisher, Ph.D.

Erik S. Herron, Ph.D.

Daniel Renfrew, Ph.D.

Department of Political Science

Morgantown, West Virginia 2021

Keywords: Energy Policy, Common Energy Policy, Punctuated Equilibrium Theory, European Union, European Parliament, Nuclear Power, Seimas

Copyright 2021 Vaida Lilionyte Manthos 


\begin{abstract}
"Energy Policy Dynamics in the European Parliament and in the Lithuanian Seimas"
\end{abstract}

\title{
Vaida Lilionyte Manthos
}

The purpose of this study is to apply punctuated equilibrium theory to better understand the development of energy policies in the European Parliament and in the Lithuanian Parliament Seimas. In the first empirical chapter I analyze written questions that members of the European Parliament submitted to the EU Commission to study whether members of the European Parliament respond to punctuating events such as the Fukushima nuclear accident. I also study party groupings in the European Parliament to evaluate how punctuating events alter the policy behavior and priorities of these party groupings. In the second empirical chapter I analyze whether political parties in Lithuanian Seimas also respond to the same punctuating events. 


\section{Acknowledgements}

I am very grateful to all of my family, friends, and colleagues. Thank you very much for your patience and support. I am especially thankful to my husband David for his support and sacrifices.

Thank you very much to my committee: Dr. Shauna Fisher, Dr. Erik Herron, Dr. John Kilwein, and Dr. Daniel Renfrew.

Thank you to the LeeAnn Greathouse and Ronny Thompson, and to all the WVU staff, especially librarians who provided me with books and other materials during the pandemic.

I am especially thankful to my adviser Dr. Kilwein. Thank you so much for your guidance, patience, assistance, and availability. 


\section{TABLE OF CONTENTS}

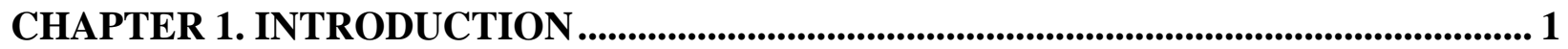

I. AMERICAN POLITICAL SCIENCE THEORIES .................................................... 7

II. PUNCTUATED EQUILIBRIUM THEORY (PET) AND PET'S

APPLICATIONS IN THE U.S .......................................................................................... 12

III. PET APPLICATIONS OUTSIDE THE UNITED STATES .................................. 17

IV. CRITICISM OF PET ........................................................................................................ 24

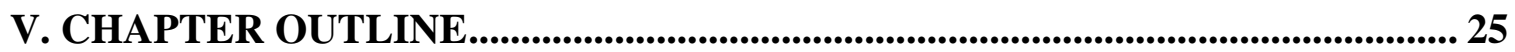

CHAPTER 2. ENERGY POLICY DEVELOPMENT IN THE EUROPEAN UNION AND

LITHUANIA …................................................................................................................................... 28

I. INTRODUCTION: COMMON ENERGY POLICY - A CONSISTENT BUT

UNREALIZED OBJECTIVE THROUGHOUT THE FORMATION OF THE EU28

II. COAL AND STEEL: FORGING A NEW UNION THROUGH ECONOMIC

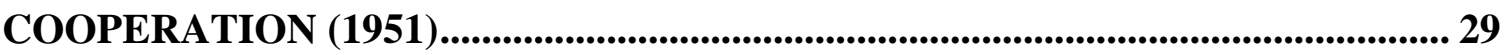

A. WESTERN EXPANSION - FIRST ENLARGEMENT (1973)....................................... 37

B. SOUTHERN EXPANSION \& STRUCTURAL CHANGES - SECOND AND THIRD

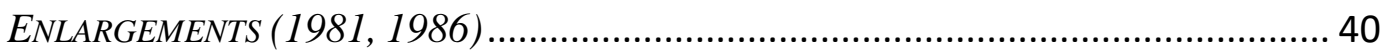

C. NORTHERN GROWTH - FOURTH ENLARGEMENT (1995).................................... 44

D. FROM ONE UNION TO ANOTHER - FIFTH AND SIXTH ENLARGEMENTS (2004) ....... 45

III. HISTORICAL CONTEXT OF LITHUANIA _.................................................................. 47 
IV. ANALYSIS - EVOLUTION OF THE EU ENERGY POLICY RELATIVE TO

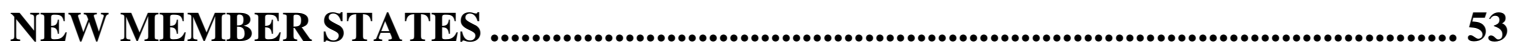

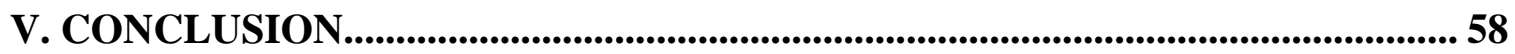

CHAPTER 3. ENERGY POLICY DYNAMICS IN THE EUROPEAN PARLIAMENT... 59

I. APPLICATION OF PET OUTSIDE OF THE UNITED STATES...................... 60

II. EUROPEAN PARLIAMENT ......................................................................... 61

III. EUROPEAN PARLIAMENTARY POLITICAL GROUPINGS...................... 63

IV. REVIEWING WRITTEN QUESTIONS TO THE EU PARLIAMENT ............ 70

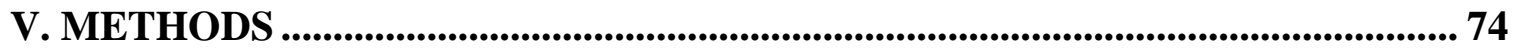

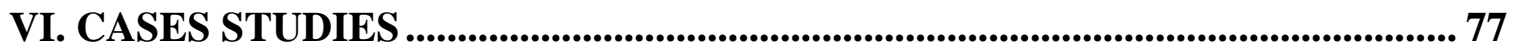

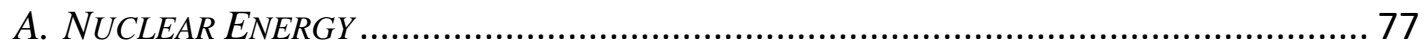

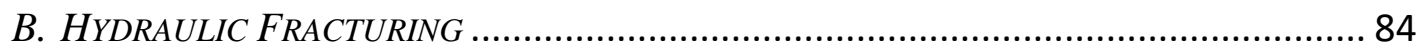

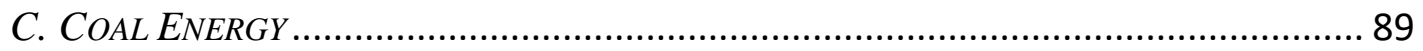

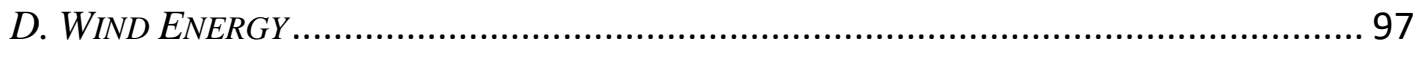

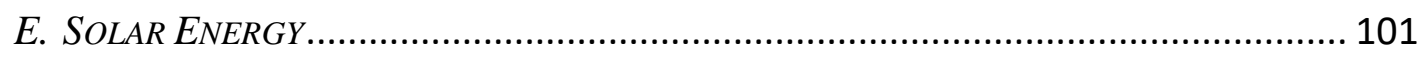

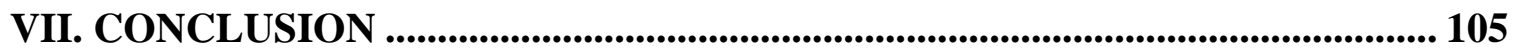

CHAPTER 4. ENERGY POLICY IN THE LITHUANIAN SEIMAS ........................... 108

I. LITHUANIA'S ENERGY POLICY ..................................................................... 111

II. INTRODUCTION TO LITHUANIA'S POLITICAL PARTIES ....................... 120

III. LAWS PASSED ON ENERGY POLICY IN THE LITHUANIAN SEIMAS.. 135 


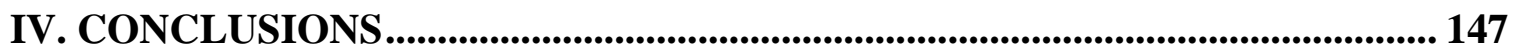

CHAPTER 5. CONCLUSION AND FUTURE RESEARCH ................................................ 151

II. FINDINGS: QUESTIONS TO EU PARLIAMENT REVEAL OCCASIONAL TENSIONS BETWEEN NATIONAL INTERESTS AND INTERNATIONAL PARTY GROUPINGS............................................................................................... 153

III. AREAS FOR FUTURE STUDY IN THE EUROPEAN UNION ..................... 155

IV. ENERGY POLICY DYNAMICS IN THE LITHUANIAN SEIMAS .............. 156

BIBLIOGRAPHY ................................................................................................................. 159 


\section{List of Tables and Figures}

Figure 1: Nuclear Energy Dynamics in Written Questions to the EU Parliament - 78

Figure 2: Hydraulic Fracturing Dynamics in Written Questions to the EU Parliament - 85

Figure 3: Coal Energy Dynamics in Written Questions to the EU Parliament - 89

Figure 4: Wind Energy Dynamics in Written Questions to the EU Parliament - 98

Figure 5: Solar Energy Dynamics in Written Questions to the EU Parliament - 102

Table 1: Lithuanian Party Groupings 1992-2016 - 134

Figure 6: Energy Policy Dynamics in the Lithuanian Seimas - 137 


\section{Chapter 1. Introduction}

Energy and environmental politics and policies have been studied and examined from different angles and perspectives by political scientists (Llewelyn Hughes and Phillip Y. Lipscy 2013, Brenda Shaffer 2009, Goldthau Andreas, and Jan Martin Witte 2010, Steve Yetiv 2015), economist (Youngho Chang, Zheng Fanga, Yanfei Li 2016), energy specialists (Thijs Van de Graaf, Benjamin K. Sovacool, Arunabha Ghosh, Florian Kern, Michael T. Klare 2016), civil servants (John M. Deutch 2011), and former U.S. Vice President (Al Gore 2006). These are just a few examples of the many scholars who have studied the complexity of energy policy. Like many other researchers, I am also interested in studying energy policy, and in my dissertation, I offer an analysis of energy policy development in two unique legislative bodies: the European Union Parliament and the Lithuanian Parliament or the Seimas.

To better understand energy policy developments in these two forums, I collected and analyzed two datasets: questions dealing with energy submitted by Members of the European Parliament (MEPs) to the European Union Commission and energy-related laws passed by the Lithuanian Parliament Seimas. I believe that this research will supplement the literature on public policy, punctuating events, energy security, energy blockades, and energy policy in general. In order to study the development of energy policy of the EU Parliament and the Seimas, I use the work of American political science and policy studies. I suggest that punctuated equilibrium theory (PET) developed to study stability and change in the U.S can also be applied to analyzing energy policy in European Parliament and in the Seimas.

First it is important to note that energy policy can be conceptualized in several different areas: energy policy driven by economic concerns, energy policy as an internal safety concern, energy policy as an external security concern, and energy policy as a supranational 
environmental concern affecting the national security, health, infrastructure, and economies of many nations. In the discussion below, I will discuss these broad categories as the principal framework for this study and discuss how different nations prioritize these aspects of energy policy decision making.

Energy policy driven by economic concerns: Energy policy is different from the rest of the world's economy and is the most capital-intensive sector. Between 2009 and 2013, energy resources accounted for almost 50 percent of total new capital raised by nonfinancial sectors. Due to capital intensity, most of the energy related projects are long lasting. For example, the infrastructure of nuclear power plants or pipelines last for 40 years (van de Graaf, Sovacool 2020, 74).

Most energy forms also require special infrastructure for processing and transportation such as pipelines, LNG terminals, and power grids. In addition, many energy networks especially natural gas and electricity distribution systems have a local monopolies that makes competition almost impossible. Despite the complexity and cost of energy infrastructure, energy is necessary for every economic activity, and energy prices influence consumer spending. According to Thijs van de Graaf and Benjamin K. Sovacool (2020) every recession in the U.S since the World War II was preceded by an upward spike in oil prices.

It is important to note that energy prices are usually altered by subsidies. Subsidies can be given to energy consumers or producers depending on the situation. States may provide assistance to poor or elderly citizens to help them heat their homes, states may offer tax credits to consumers and businesses for investing in more efficient infrastructure and vehicles, and states may subsidize entire sectors of energy production in the interest of local economies or domestic energy security. Subsidies can encompass all areas of the energy sector from fossil fuels and 
nuclear energy to the renewable energy sources. In 2013, fossil fuel consumer subsidies accounted for US\$548 billion (van de Graaf, Sovacool 2020, 82).

Many countries use energy subsidies with the expectation that these subsidies will promote economic growth and economic development. In reality, energy subsidies often lead to the excessive energy consumption and accelerate resource depletion and large government revenue losses (Kosmo 19-20, 1987). Between 2015 and 2018 around 50 countries attempted to reform fossil fuel subsidies, but very often citizens expect them from the government, making these reforms difficult to implement. For example, attempts to reform energy subsidies led to unrest in at least 24 countries between 2006 and 2019, including the Gilet Jaunes (yellow vest) protests in France, and other mass demonstrations in Ecuador, Nigeria, Zambia and other countries (Bassetti, Landau 2021). Fluctuations in energy prices, expensive energy infrastructure, and energy subsidies impact world economies and people's lives.

Energy policy as an internal safety concern: This energy concept is related to nations' internal affairs. For example, countries that have long history of coal mining and endured coal mine disasters in the past pay more attention to the coal mining safety. Recent coal mine disasters in Ukraine (2007), China (2007), South Africa (2009), Colombia (2010), and Siberia (2010) reminded policy makers and the citizens of these countries that mining is a dangerous occupation. Coal miners in China are particularly vulnerable to mining related accidents due to poor training and inadequate security measures (Chronology: Major mining disasters 2014).

Disasters in coal mines raise awareness about coal mining safety in countries and regions that have active mines, but nuclear power disasters cause major security concerns not only to the countries where these disasters occur, but to the entire world. In the first decade of the new millennium China and India planned to build about 100 nuclear power reactors over the next 25 
years, but the Fukushima nuclear accident in 2011 reminded decisionmakers about the danger of the nuclear power, and public protests against this energy source intensified around the globe. The Fukushima accident was not the first nuclear accident in the history of the nuclear power, e.g., the Windscale Accident in 1957, Three Mile Island in 1979, and Chernobyl in 1986 also caused widespread fear and public protests in Europe and in the U.S (Srinivasan, Rethinaraj 2013, 2012).

Due to safety concerns, Lithuania and Latvia fiercely resisted the new nuclear power plant that Belarus decided to build a mere 50 kilometers from Vilnius, the Lithuanian capital. Despite the opposition from its neighbors, Belarus started operating its first nuclear power plant, but Lithuanian and Latvian policymakers vowed not to purchase electricity generated by this new power plant (Belarus Launches Nuclear Power Plant Despite 'Safety Issues', 2020). As a response to the nuclear power plant in Belarus, Lithuania started conducting drills to prepare its citizens to be ready to respond to a possible nuclear disaster (BNS/TBT Staff 2021).

New methods of energy extraction also caused some major internal health and safety concerns. For example, hydraulic fracturing (a method to extract shale gas) was linked to aquifer contamination, heavy traffic, harmful respiratory impacts from living and working nearby, and seismic shocks. All of these negative outcomes of hydraulic fracturing caused public uproar in some countries that have substantial shale gas deposits. As a result, France and Bulgaria completely banned shale gas exploration, while Poland and the United Kingdom issued permits and granted tax breaks to support shale gas extraction (Graaf, Debaere 1, 5, 2017).

Even renewable energy sources have caused some public dissatisfaction in certain countries and regions. In many German states, local populations disapproved of building new wind turbines or replacing older ones with the modern turbines. For example, citizens of the state 
of Brandenburg cited safety concerns such as noise caused by the wind turbines, and in a very short time collected 15,000 signatures against wind farm expansion (Meyerhoff, Hartje 1, 2010).

Energy policy as an external security concern: In many countries national security is closely link to the energy security and a concept of energy policy as an external security concern has been researched by a number of political scientists. Randall Newham (2010), Margarita Mercedes Balmaceda (2013), Neringa Miliauskaite (2014), Agnia Grigas (2016), and others have studied energy policy as an external security concern for Lithuania. All of these researchers emphasize the fact that Lithuania has been dependent on Russian energy and that Russia threatens to Lithuania's national security.

However, Lithuania's position is not unique; at different points in history, many countries have used energy as a tool to reach their geopolitical goals. Andreas Goldthau (2011) provides examples how energy diplomacy, or the lack thereof, has been used in the past, e.g., the U.S. oil embargo against Japan in 1941 was designed to force Japan to withdraw its troops from occupied China. Goldthau argues that this embargo was the main cause for Japan's declaration of war against the U.S. in 1941 (Goldthau 2010, 27).

Richard A. Simmons, Eugene D. Coyle, and Bert Chapmans' (2014) study emphasized how through its natural resources Russia gained geopolitical leverage in the Arctic Ocean, Europe, the Caspian Sea region, and in the former Soviet states. Similarly, in their analysis of energy policy in the EU, van de Graaf and Sovacool note that the brief drop in gas supplies in 2006 and the Russian-Ukrainian gas crisis of January 2009 served as a wakeup call for the EU and showed the EU Commission that there is much work to do in terms of continental energy security. 
Energy policy as a supranational security concern: Global climate change poses a new challenge to the international community. Unfortunately, attempts to combat climate change have not been very successful, because many countries are reluctant to change their energy systems for a global goal. For example, in 2001, the U.S. decided not to join the Kyoto Protocol, an international treaty that encouraged countries to reduce greenhouse gas emissions and stop global warming (Eberlein 2012, 164).

China, the U.S., the European Union, India, Russia and Japan are the largest emitters of CO2. China surpassed the U.S in 2006 and is currently the largest emitter of the CO2. Also, each nation's emission profile is very different: the U.S. and China's emission primarily comes from energy and transport, while Brazil and Indonesia's come from deforestation and changes in land use (van de Graaf, Sovacool 2020, 97).

Besides global climate change, there are different environmental problems link to the energy use and different types of power plants. Water use and water contamination is a "site effect" of the use of power plants. According to van de Graaf, Sovacool, power plants used in different energy sectors withdraw trillions of gallons of water from local aquifers and lakes, and as a result, contaminate water supplies at various parts of their fuel cycle.

Energy policy as supranational security concern has recently received growing attention. Brenda Shaffer (2009) conducted comprehensive research on energy politics and energy security in the European Union and in the U.S. She discusses how climate change has shifted energy and environment debates. In the past, climate change was considered a quality of life issue, but in 2007 the UN Security Council recognized climate change as a global security issue (Shaffer 2009, 105). Energy policy cannot be debated without discussing climate change, and other 
environmental issues, putting renewable energy sources such as wind and solar at the forefront of these discussions.

This study uses these four categories to define energy policy, and from them I analyze the different ways that nations prioritize these aspects of energy policy. Energy policy priorities are framed in different ways by different countries, depending on national or regional needs, and global concerns. Additionally, public opinion, organized campaigns, and new information can cause priorities to shift over time.

What follows below, is an overview of the potentially relevant American political science theories: PET, the Multiple Streams Model (MSM), and the Advocacy Coalition Framework (ACF). I propose that among these, PET is the most applicable to my study of the EU Parliament and the Lithuanian Seimas, because it addresses punctuating events, incremental changes, and energy policy framing.

\section{American Political Science Theories}

Multiple Streams Model: As an American political science student I am interested in testing whether political science theories originally developed in the U.S can be applied in the European context. The first of the theories I considered applying is the Multiple Streams Model (MSM), also known as the Garbage Can Model, developed by John Kingdon (1995). Kingdon argues that the majority of decisions made in the policy process are not made rationally (Kingdon 1995, 124). Rather, according to Kingdon, the policy process in the U.S is like a primeval soup of policy with three independent streams: problems, policy, and politics.

First, Kingdon argues that problems are not self-evident, and before becoming problems, they are indicators. Indicators may exist for a long time, until a focusing event such as a crisis or disaster calls attention to them and helps to transform the issue into a problem that warrants 
attention (Kingdon 1995, 95). However, even the occurrence of a focusing event does not guarantee that a particular issue reaches a policy agenda. Kingdon argues that a disaster or crisis becomes a focusing event only when disaster acts as an early warning of a problematic condition. For example, the collapse of the Silver Bridge across the Ohio River in 1967 was an indicator of a widespread problem - decaying bridges. As a result of the collapse, Congress established and funded a program for bridge inspection and over 80,000 deficient bridges were found (Kingdon 1995, 98).

Sometimes a focusing event becomes a problem after a second occurence, or in combination with similar problems. The collapse of one bridge or a single aviation accident may not create a sense of a general problem by itself, but the occurrence of multiple events together may reveal a hidden problem (Kingdon 1995, 98).

The second stream that Kingdon discusses is the policy stream. This stream is based on policy communities which consist of specialists in a given policy area. Every policy area has a community that can be fragmented or strong. According to Kingdon, fragmentation leads to instability. Kingdon argues that ideas, and proposals circulate inconsistently in a policy stream because policy communities encompass many individuals, including researchers, congressional staffers, people in evaluation and budget offices, and academics (Kingdon 1984, 116). All of them can propose policy ideas, but most of these ideas do not survive and do not reach the agenda setting stage.

Successful ideas tend to meet several criteria. First, is technical feasibility: some ideas might "look attractive" but are hard to implement and administer because of technical difficulties. Policy makers do not always anticipate all the consequences of their idea, and as a result these ideas fail (Kingdon 1984, 132). Value acceptability is another criterion that 
determines an idea's survival. Kingdon emphasizes that proposals that do not line up with national or specialists' values have less of a chance of being accepted (Kingdon 1985, 133).

Finally, the last stream that Kingdon discusses is the political stream. This is the most important stream because it has the most influence on new agenda setting. Kingdon defines the political stream as a set of electoral, partisan and pressure groups (Kingdon 1985, 145). He argues that some issues in the political stream become prominent while other issues and problems are shelved until a more favorable time (Kingdon 1985, 145). According to Kingdon, national mood is also an important factor that limits whether an issue reaches the agenda setting stage or not. Later, Kingdon explains that national mood is not always captured in surveys and polls, because politicians, and government officials also hear from interest groups leaders, public officials, read newspaper editorials, and receive question at the townhall meetings. Their active participation in public life allows them and their assistants to collect information independently (Kingdon 1985, 149).

Some political scientists have criticized the MSM for its unpredictability and ambiguity. Mucciaroni (1992) criticizes Kingdons' MSM for its inability to be applied to other countries besides the US. According to Mucciaroni, the MSM may be useful for describing policymaking in the U.S because the U.S has a fragmented institutional structure and temporary coalitions, but the MSM cannot be applied elsewhere because other countries do not have such fragmented structures as the U.S. Mucciaroni argues that institutional structure in the U.S is fluid and coalitions between policy makers are often temporary and $a d$ hoc. In contrast, policy making in other countries occurs in institutions that are more organized and integrated, hence policy making in other democracies are more "stable, predictable, and orderly" (Mucciaroni 1992, 466). 
Similarly, Nikolas Zahariadis (1999) argues that the MSM only deals with policymaking under conditions of ambiguity that make policy-making messy, complex, and less comprehensible, when in reality policy changes in American public policy are rational outcomes of historical legacies (Zahariadis 1999, 90).

Advocacy Coalition Framework theory $(A C F)$ : Another policy theory I considered for my work is the Advocacy Coalition Framework theory. ACF theory proponents focus on processes driven by political actors that promote their beliefs. Paul Sabatier and Christopher Weible highlight the beliefs of policy participants and argue that they are motivated to transfer these beliefs into actual policy (Sabatier, Weible 2007, 192). In other words, beliefs are the main factors that encourage policy makers to take sides with and join advocacy coalitions that share the same belief system. Conversely, advocacy coalitions with opposite policy beliefs compete to gain influence and favorable policy outcomes. Competition between coalitions create long term stability because policy core beliefs are unlikely to shift and one coalition may dominate others for a long time period (Cairney 2007, 200).

ACF theory suggests that major policy changes require external and internal shocks, and similar to the MSM, stresses the notion that sudden changes come after years of stability. But, unlike the MSM, ACF theory puts a major emphasis on policy beliefs and classifies them as deep core beliefs, policy core beliefs, and secondary aspects (Cairney 2007, 205). Deep core beliefs are introduced in childhood and are, often, impervious to empirical evidence. Religious convictions and philosophical principles are good examples of deep core beliefs which are almost impossible to change. Deep core beliefs operate on a traditional left and right/liberal and conservative scale (Cairney 2007, 205; Sabatier, Weible 2007, 195). 
Policy core beliefs represent essential policy positions, such as a position on the proper balance between government and market, or a position on the proper distribution of power across levels of government, etc. Like deep core beliefs, policy core beliefs are hard to change, but they tend to be a bit more flexible. For example, in the Lake Tahoe Basin, California, policy participants had been divided into two groups: those who were supportive of land preservation and others who were in favor of development. Though their core beliefs were different, they were still able to agree on preventing urban development on steep slopes with severe erosion (Sabatier, Weible 2007, 195).

Secondary aspects or beliefs do not bear the same importance as deep core and policy core beliefs. Secondary aspects address rules, project funding and implementation of policy goals, information gathering, etc (Cairney 2007, 205). Unlike deep core beliefs and policy beliefs, secondary aspects are associated with technicalities; therefore, changing them requires less evidence and fewer agreements among actors of the policy making (Sabatier, Weible 2007, 196).

ACF theory suggests that policy participants seek alliances with legislators, agency officials, interest group leaders, judges, researchers, and intellectuals from multiple levels of government who have similar policy core beliefs in order to form an advocacy coalition. Proponents of ACF theory suggest that advocacy coalitions are better suited for explaining the behavior of organizations and individuals who are involved in a particular policy area over long periods of time because competition among different coalitions creates a balance (Sabatier, Weible 2007, 196).

ACF theory is potentially useful for my work because it puts an emphasis on the internal shocks that can change the course of the existing policy. In addition, studies based on ACF 
theory investigates the behavior of organizations and individuals over long periods of time. Proponents of the ACF theory suggest that advocacy coalitions are self-contained entities (Jones, Jenkins-Smith 2009, 40). My concern for this study is that given the EU Parliament's supranational nature, the MEPs who represent their nation states do not have the opportunity to develop long-term connections over time and are less likely to have similar and consistent positions on particular issues such as energy policy.

The MSM and ACF theory are valuable and useful policy theories that have been used to explain U.S. behavior and applied comparatively abroad, but I believe that Punctuated Equilibrium Theory (PET) is the most suitable theory to study energy policy dynamics in the European Parliament and in the Lithuanian Parliament. In the following sections, I review PET and its applications in the U.S and argue that it is the most useful model for this study.

\section{Punctuated Equilibrium Theory (PET) and PET's Applications in the U.S}

Punctuated Equilibrium Theory (PET) offered a new perspective on policy-making processes and is an alternative to the traditional political science models of the mid-20th century. Proponents of PET theory suggest that large-scale policy changes can be associated with electoral changes, subsystem dynamics, or with a sense of urgency that overwhelms the political system and forces political actors to unite (Baumgartner, Jones 2012, 21). According to PET, which was first developed with the U.S. political system in mind, most policymaking is in the hands of policy subsystems (Baumgartner, Jones 2012, 23). Policy making by subsystems is susceptible to media coverage, policy entrepreneurs, negative and positive images, and a variety of other factors that impact "the life span" of particular policies and, arguably, subsystems (Baumgartner and Jones 2012, Kingdon 1995, McCool 1998, Thurber 1991, and Worsham 1997). 
Recently, a host of scholars have extended the PET model to a European setting. ${ }^{1}$ I am interested to extend this trend and apply PET to my study of EU and Lithuanian energy policies, but first it is important to review PET in the American political context. What follows reviews the literature with a focus on how policy equilibriums are created and destroyed, taking care to identify and discuss the actors involved in the agenda-setting processes.

Baumgartner and Jones argue that changes in American public policy occur not just through elections, but also through policy-by-policy adjustment processes (Baumgartner, Jones $2012,3)$. In other words, they believe that incremental changes at the subsystem level occur quite often and that these changes do not depend on election cycles. In their study, they examine several policy subsystems (nuclear power, pesticides, drug and alcohol abuse, smoking and tobacco, automobile safety, urban policy, and child abuse), but in this section I focus on nuclear energy because the nuclear energy subsystem become the most vulnerable policy subsystem in the European Parliament.

Baumgartner and Jones argue that support for nuclear power declined among American policy makers and the general public when its policy image changed from positive to negative. This change did not happen overnight. During the 1940s and 1950s, nuclear power enjoyed a positive image. In 1946, Congress created the Atomic Energy Commission (AEC), which was supported by corporate and political elites; public opinion towards nuclear energy was also positive. That situation changed dramatically after the accident at Three Mile Island (TMI) in 1979. Public attention on nuclear power increased, and negative articles referring to nuclear energy started to emerge. As a result, in the 1980s, negative headlines outnumbered positive

${ }^{1}$ Petya Alexandrova, Marcello Carammia and Arco Timmermans (2012), Richard Youngs (2011), Sebastiaan Princen (2009), Marcello Carammia, Sebastiaan Princen and Arco Timmermans and Petya Alexandrova (2013), Peter John and Shaun Bevan (2012) and a general Comparative Agendas Project team 
ones, journalists who covered nuclear energy began asking more critical questions, and scientists raised credible questions about the safety of nuclear power. In addition, AEC staff started questioning the agency's safety procedures, creating an internal crisis. Soon after that, nuclear energy's golden years came to end (Baumgartner, Jones 2012, 65-67). Baumgartner and Jones collected and analyzed the transcripts of hearings on civilian nuclear power topics in congressional committees from 1945 to 1987 . They coded the tone of these meetings as negative, neutral, and positive. Negative topics included accidents in nuclear reactors, regulatory reforms, worker safety, waste disposal etc. Positive assignments were given to topics like new technologies and growing demand for electricity. A neutral assignment was given to annual appropriation hearings and committees where the tone could not be identified.

Baumgartner and Jones' analysis revealed that nuclear power questions received very little attention in the post war era, except from congressional hearings with involvement of a few committees. However, the number of hearings on nuclear energy had increased from 16 hearings per year during 1955 to 1968 to 51 per year from 1969 to 1986 (Baumgartner, Jones 2012, 73, 74).

In the 1950s, the nuclear energy policy subsystem received some objections from labor unions, local activists, and environmentalists, however, the voices of opposition were overshadowed by the positive image of nuclear energy. In 1969, the National Environmental Policy Act came into effect, and requirements for environmental impact assessments of all federal licensing procedures were enacted. Soon after that, the courts become hostile to the AEC, and the positive image of the nuclear energy started incrementally changing from positive to negative at the state and local level. As a result, in 1974, the AEC was dismantled and eventually replaced by the Department of Energy (Baumgartner, Jones 2012, 69). 
The nuclear energy policy subsystem lost its positive image at the same time it lost control over of the issue. Opponents of nuclear energy were successful in expanding their reach to licensing, oversight, and ratemaking, which fated nuclear energy to a growing negative perception problem (Baumgartner, Jones 2012, 70). Then the TMI accident served as a major triggering event, after which opponents of nuclear energy outnumbered supporters by 60 to 30, and the positive image of nuclear energy could not be restored (Baumgartner, Jones 2012, 80).

The case of nuclear power is also an example how framing of the nuclear energy has incrementally changed over the years. In 1957, Congress conducted a lot of hearings on nuclear power and most of these hearings were supportive of the industry. These hearings focused on “development, growth, and state of the atomic energy industry", but in 1976, ten of twelve hearings focused on problems of reactor safety, nuclear waste disposal, and the safeguarding of materials. (Baumgartner, Jones 2012, 257, 259). Safety concerns intensified even more after the Three Mile Island accident in 1979 and framing of nucelar energy was no longer driven by the economic concerns but instead by internal security concerns.

Similar to Baumgartner and Jones, Thomas Birkland sought to explain punctuations in the policy equilibrium and discusses the importance of a focusing event. Birkland argues that focusing events serve as important opportunities for politically disadvantaged groups to deliver messages that had been suppressed by dominant groups (Birkland 1998, 54). Birkland began to study congressional hearings held on earthquakes and hurricanes from 1960 to 1990, oil spills from 1968 to 1990, and power plant accidents from 1977 to 1990, and concluded that focusing events appear to change dominant issues on the national agenda. Focusing events can mobilize groups because they lead interest groups, government leaders, policy entrepreneurs, and the media to pay greater attention to existing, but undeveloped problems (Birkland 1998, 55, 58, 72). 
In other words, with help from focusing/triggering events, low-attention policy subsystems can move to the higher level and reach the agenda-setting stage. In addition, focusing events change the way certain issues are framed. After the World War II, policy makers expected that nuclear enery would foster economic growth, but after the Three Mile Island accident, nuclear energy instead become a safety issue.

PET's applications were not limited to the nuclear disasters, oil spills, and natural disasters. In another study, Frank Baumgartner investigated dramatic changes in pesticides policy. In the Post War era, pesticide policy enjoyed a positive policy image. Newspaper articles emphasized the benefits that pesticides had on agricultural productivity, and stressed that the use of pesticides would help to end hunger. In other words, pesticides policy was perceived/framed as an economic issue that would help to reduce poverty and reduce world hunger. Negative articles focused on the danger pesticides posed to certain species, and on how their toxicity threatens the environment. Over time, negative media coverage of pesticides significantly overtook positive attention (Baumgartner 2006, 28).

Although pesticides policy did not experience a punctuating or focusing event, like the Three Mile Island Accident, negative newspaper coverage helped to change pesticides policy in the U.S. Policy makers who once promoted pesticides as a way to help farmers had to acknowledge the growing public concerns about its negative impact on the environment. After the creation of the Environmental Protection Agency in 1970, negative newspaper coverage referencing pesticides increased even more (Baumgartner 2006, 29). Therefore, framing of pesticides policy changed from a focus on economic benefits to health and environmental concerns.

Another relevant PET case study covers federal spending on energy conservation. Prior to the increase in oil prices and the resulting gasoline shortage of 1973, little or no attention was 
given to energy conservation. However, in 1977, a $\$ 575$ million dollar fund was established to address energy conservation. In 1978, this fund increased to $\$ 1.2$ billion. According to Baumgartner, this federal spending on energy conservation is a clear example of a policy not being considered relevant to the U.S government until the jump in the price of oil (Baumgartner 2006, $32)$.

PET applied in the U.S context reveals how a punctuating event can shift a policy's image from positive to negative. While nuclear energy received some negative attention in the U.S. prior to the TMI accident, that crisis was a clear triggering event that significantly undercut this energy source's image. Still, triggering events are not always necessary to initiate a policy change. In the case of pesticides, the policy changed due to incremental and consistent negative media attention over time. PET also reveals how incremental changes and/or punctuating events can change policy framing. After World War II, nuclear power was framed as an issue of economic growth, but after several decades nuclear power become an issue of safety. The pesticides policy also underwent similar changes in the policy framing, i.e., from an issue of economic growth to an issue of health and environmental concerns.

\section{PET Applications Outside the United States}

Inspired by PET's success in studying stability and change in the U.S., researchers applied the theory to the European context. Petya Alexandrova, Marcello Carammia, Sebastiaan Princen, and Arco Timmermans are those researchers who apply punctuated equilibrium theory in studying agenda-setting processes in the European Union. Together they contribute to the European Union Policy Agendas Project where they conduct more in-depth analyses on specific policy themes and to the Comparative Agendas Project (CAP). Alexandrova, Carammia, Princen, and Timmermans completed and released a dataset on European Council Conclusions from 1975 to 2014, thus most 
of their work focuses on policy changes in the European Council (Datasets, European Union, CAP).

In 2015, Petya Alexandrova (2015) employed a variation of PET theory to study focusing events in the European Council. She studied man-made accidents and natural disasters and suggests that man-made accidents have a higher chance of being discussed than natural disasters in the context of the European Council. Events that resulted more casualties also have higher likelihood to be featured on the agenda and gain more attention in the Council. Alexandrova argues that focusing events occurring in geographically closer countries and in democratic countries tend to receive more attention in the European Council than the events occurring in the countries that the EU does not have close relationships. To test these hypotheses, Alexandrova counts man-made disasters and natural incidents listed in the International Emergency Disaster Database, Peace Research Institute Oslo (UCDP/PRIO), Armed Conflict Dataset, and the RAND Database on Worldwide Terrorism Incidents. Then she analyzes whether these disasters and incidents were discussed in the Conclusions of the European Council. Alexandrova's research covers the period from 1975 to 2012, and she finds support for most of her hypotheses. She claims that man-made events with high number of casualties that occur near EU receive more attention in the Council's meetings than natural disasters or manmade events occurring in further regions and countries (Alexandrova 2015).

In another article, Petya Alexandrova, Anne Rasmussen and Dimiter Toshkov (2016) study whether the European Council responds to the policy priorities of the European citizens from 2003 to 2014. They rely on a dataset of the European Council Conclusions that were coded via the EU Policy Agendas Project Codebook, an adapted version of the Policy Agendas coding system developed by Baumgartner and Jones. To measure public opinion, they use a question derived 
from the Eurobarometer survey: "What do you think are the two most important issues facing our country at the moment?" (Alexandrova, Rasmussen, Toshkov 2016, 612). To assess the correspondence between public priorities and the agenda of the European Council and to investigate the possibility of rhetorical responsiveness they measure the strength of correspondence between the public's list of priorities and the European Council's priorities. Alexandrova et al. found some evidence of a correlation between public opinion and the attention of the European Council, and that this correlation has increased over time. However, the European Council puts high emphasis on foreign policy and defense matters and directs less attention to other issues that are important to the public (Alexandrova, Rasmussen, Toshkov 2016, 622).

In another article applying PET to the European context, Marcello Carammia, Sebastiaan Princen and Arco Timmermans (2016) investigate whether the agenda of the European Council shows substantial change over time. In this study, they again rely on the comprehensive dataset of coded European Council Conclusions in the period of 1975 to 2011. In their analysis, they analyze the scope of fragmentation and instability in the European Council's agenda. They investigate how and if attention to the topics of economic governance, employment policy, social policy, defense policy, foreign and security policy, immigration, and crime have changed over time (Carammia, Sebastiaan Princen and Arco Timmermans 2016, 817). They reach a conclusion that the European Council has increased its agenda management capacity and become more involved in a wider range of issues within the EU. However, the EU did not dedicate its attention to newer intergovernmental policy areas, but instead broadened its agenda across a wide range of issues (Carammia, Sebastiaan Princen and Arco Timmermans 2016, 822).

Will Jennings, Stephen Farrall, Emily Gray, and Colin Hay (2020) apply PET to analyze the criminal justice policy agenda in Britain, and in addition, to the focusing events that are 
defined as "moral panics". Moral panics are associated with society's fears and anxieties, and they can help to define and frame a policy issue. The authors argue that a "moral panic" singles out an event or set of processes that occur randomly but are perceived as representation of the moral decay or crisis in the society (Jennings, Farrall, Gray, and Hay 2020, 210). For example, in 1993, a toddler named James Bulger was murdered by two other underage children. This murder become a "moral panic" in British society as it put a spotlight on other concerns. Soon after this murder, the media started to focus on child delinquency, family breakdown, and the loss of respect for traditional values. In this way, the murder of a little boy was discussed as a far wider set of processes associated with rapid economic and societal changes and decline (Jennings, Farrall, Gray, and Hay 2020, 211). This "moral panic" caught the attention of policy makers who started responding to the public's concerns regarding crimes. Prior 1970s, crime rates in the Great Britain were relatively low and the topics of law and order was fairly low on the policy makers' agenda, but after the murder of James Bulger, crime emerged as a prominent issue on the policy agenda in the government (Jennings, Farrall, Gray, and Hay 2020, 212).

In 1995 and 1997, the percentage of the Acts of the British Parliament related with the issues of crimes substantially increased. In 1995, the UK Parliament passed 17 acts that addressed crime, and the issue of crime in 1995 comprised 31 percent of all of the government's legislative agenda. The law and order sentiment were also felt in the Queen's Speeches (Jennings, Farrall, Gray, and Hay 2020, 212).

Another case study in the UK was conducted by Peter John and Shaun Bevan (2012) on the UK Government from 1911 to 2008 . They identified punctuating events from the Acts of the UK Parliament using historical records and data analysis. These records cover about 100 parliamentary sessions and include 19 major topic codes (John, Bevan 2012, 93). By doing so, 
John and Bevan identified three kinds of policy changes, and each of these policy changes had a different level of importance within the British political system. The first kind of punctuation in the data was a combination of unrelated activities. The second set of punctuations were large and connected with policy changes, but not significant enough for the public to notice them as they did not impact their daily lives. And the third set of punctuations were the high-salience punctuations that receive media attention as well as attention from the public and resemble the policy changes described by Baumgartner and Jones (John, Bevan 2012, 104). Therefore, the media's and public's attention are important for policy change to happen.

Besides the EU Council and the U.K, some political scientists attempted to apply PET to the international organizations (IOs). Magnus Lundgren, Theresa Squatrito, and Jonas Tallberg (2017) examine data on the policy outputs of the African Union, the European Union, the Organization of American States, the Organization of Islamic Cooperation (OIC), and the United Nations between 1980 and 2015 (Lundgren, Squatrito, and Tallberg 547, 549, 2017). They analyzed about 20,000 individual policy decisions that covered sixteen topics, ranging from security and defense to climate change. They suggest that PET is applicable to a broader empirical domain and can even be used in studying international relations (Lundgren, Squatrito, and Tallberg 547, 2017).

Lundgren (et al.) argue that in theory, IOs share a lot of similarities with the American political system; therefore, PET may help to explain policy changes that occur in IOs. Similar to decision-making processes in the domestic American political system, IOs have to respond to ongoing social processes, such as sudden wars, famines, epidemics, crises in financial systems, migration flows, and environmental disasters. Lastly, like national political systems, IOs are not 
capable of efficiently responding to challenges due to capacity limitations (Lundgren, Squatrito, and Tallberg 552, 2017).

The study further suggests that variation across these five international organizations has a lower leptokurtosis than those within the European Union. That means that punctuating events in the EU are not so significant in comparison with the other IOs. To Lundgren et al., this difference may be due to similar political systems among the EU countries, which gives the EU lower institutional friction. In contrast, OIC and UN members are heterogeneous and are associated with the highest levels of institutional friction (Lundgren, Squatrito, and Tallberg 562, 2017). The authors suggest that PET can be applied in different international organizations and countries even though PET was developed to study stability and change in the United States.

Jeremmy Shiffman, Tanya Beer, and Yonghong Wu (2002) argue that PET is the best theory to study global priorities in controlling diseases such as polio, malaria, and tuberculosis because these diseases underwent surges in efforts to eradicate them, but over time these efforts subsided until the next cycle of attention. They point to the case of polio, which received a sudden burst of attention during a time when eradication efforts had stabilized at disappointing levels of coverage. While the vaccine to prevent polio was developed in 1961, polio eradication efforts accelerated only in the mid-1990s with the international immunization day. Polio received some attention between 1961 and 1990, but that attention was not significant (Shiffman, Beer, Wu 2002, 227).

The case of malaria is similar: malaria posed a major public health threat before the World War II, but only the discovery of dichlorodipheny dichloromethane (DDT) during the war encouraged global efforts to eradicate this disease. DDT was sprayed in malaria-endemic areas to reduce the number of infected mosquitoes below a critical level of density since it was believed 
that malaria parasite will no longer be transmitted. By 1973, cases of malaria were reduced in India and Sri Lanka, but increased in Central Africa and Southeast Asia. Around the same time, smallpox was competing for the attention in the global health community, hence malaria moved off the top of the global disease agenda (Shiffman, Beer, Wu 2002, 228).

The World Health Organization (WHO) struggled to receive attention regarding malaria eradication from the international health community until a global malaria control strategy was ratified in Amsterdam in 1993. With technical backing from the WHO, the World Bank prioritized projects that addressed fighting malaria, and as a result it again rose to the top of the agenda in the global health community (Shiffman, Beer, Wu 2002, 229).

The case of tuberculosis (TB) policy also experienced similar punctuations in the policy equilibrium: antibiotics to cure TB were invented in 1944 and after reaching success in reducing incidents of TB and mortality rates in the developed world, governments and health leaders ignored the disease. In 1986 Margaret Thatcher disbanded the Medical Research Council which was founded to respond to the TB crisis. The WHO also ignored TB, and its disease related publications dwindled to almost nothing by the late 1980s (Shiffman, Beer, Wu 2002, 229). TB returned to the agenda in 1986, when the Center of the Disease Control (CDC) noticed that TB cases in the U.S had started to increase after a 30-years downward trend. As the result, the Advisory Council for Elimination of Tuberculosis (ACET) requested more funding to address this reemerging problem and major international organizations such as WHO and the World Bank started paying more attention to the TB.

After discussing these case studies, Shiffman et al. conclude that the history of polio, malaria, and TB control all display a punctuated pattern (Shiffman, Beer, Wu 2002, 230). Their study suggests that PET is applicable in studying disease control and how the international 
organizations such as the WHO, the World Bank, Rotary International, the United States Agency for International Development (USAID) responded to the spread and control of these diseases.

However, they did not collect or display data from the period of time of their study (such as the WB projects, resolutions, documents, etc.) that would have strengthened their statement that PET is the most suitable theory to study the disease management and control. Lack of data and empirical research has been one of the criticisms of the PET, hence in the discussion below, I briefly discuss PET's shortcomings and the possible ways to address them.

\section{Criticism of PET}

Thus far, I have discussed the literature on punctuated equilibrium theory and its applications in the U.S and in the other organizations and countries. Authors of these studies argue that PET is applicable in studying diverse political systems and international organizations.

However, Johanna Kuhlmann and Jeroen van der Heijden (2018) criticize PET theory and its applications and argue that PET cannot be easily applied to multiparty political systems because it puts too much emphasis on federalist structures and minimizes the role that political parties play in the policy-making process (Kuhlmann, Heijden 2018, 330). In addition, they question the frequent use of PET in political science studies and claim that most researchers who cite PET use secondary data instead of original empirical research (Kuhlmann, Heijden 2018, 328). When Kuhlmann and Heijden analyzed articles that referred to PET, they discovered a discrepancy between the high number of articles that cite the core PET readings and relatively few articles that operationalize PET to analyze policy change (Kuhlmann, Heijden 2018, 336). Specifically, they found only 86 studies that operationalized PET and argued that substantial PET applications are rarely found. They concluded that "PET applications raise the question of 
how this knowledge can be generalized and help drawing lessons on policy change that transcend the individual empirical studies" (Kuhlmann, Heijden 2018, 341).

I acknowledge Kuhlmann and Heijden's criticism of generic references to PET, therefore, in my study I collect and analyze original EU Parliament and Seimas data. I believe that datadriven empirical applications of PET, such as Baumgartner and Jones' studies of agenda-setting process in the US and European countries, are valuable where the theory is truly applied using original data. There is no a universal theory or a research method that would completely explain different energy policies in countries and organizations, but I believe that punctuating equilibrium theory is the most valuable to study energy policy dynamics in the EU Parliament, and in the Lithuanian Parliamen. PET focus on sudden policy changes within years of stability, and this is what I am interested in exploring in my study. I conclude this chapter below by briefly introducing the subsequent four chapters of my dissertation.

\section{Chapter Outline}

In the second chapter, I provide a historical context of the European Union and Lithuania to better understand the development of energy policy in these two settings. I discuss the creation, expansion, and evolution of EU energy policy over the course of the six EU enlargements. I also introduce the reader to the main EU institutions and their functions as well as their development. I briefly review the energy mixes of EU members and suggest that different energy sources and different relations between the EU members and their main energy suppliers prevented the EU from creating a common energy policy.

Russia has been the main energy supplier to Lithuania and to the other EU member countries. However, Lithuania has had especially strained relations with Russia for centuries and as a result actively sought membership in the EU and NATO as counterweights. While creating 
great difficulty for it, Lithuania acceded to the EU requirement that it decommission its only nuclear power plant in order to join the EU. Once in the EU, Lithuania also advocated for common energy policies. Punctuating events such us disturbance of the gas supply to Western Europe, climate change, and pressure from the new member states finally encouraged the EU to make energy policy a priority.

In the third chapter I investigate the EU Parliament and my analysis is built on the PET. I analyze energy related questions that members of the European Parliament (MEPs) submitted to the EU Commission from 1994 to 2014, and I look for possible punctuating or focusing events that might have impacted nature of these questions. I suggest that the Fukushima accident in 2011 prompted MEPs to submit more critical of the nuclear energy questions to the EU Commission. Following the Fukushima accident, other energy sources (coal energy, wind, and solar) also received more attention from the MEPs. In this part of my dissertation, I also analyze MEP political party groupings and their platforms on energy and the environment. In other words, I analyze what written questions to the EU Commission can reveal about political party groupings and their behavior.

In my fourth chapter I study energy related laws in the Lithuanian Parliament, or Seimas which were passed from 1992 to 2016. In this section, I review the main Lithuanian political parties and discuss how despite their partisan and policy differences, all supported Lithuania's membership in the EU and agreed to comply with the EU's demands to close the Ignalina nuclear power plant. This is not the behavior I originally expected from the different political party groups of Lithuania. I suggest that the memories of past Russian energy blockades and other aggression towards Lithuania galvanized Lithuanian policy makers from all of the political parties to seek EU membership, no matter the cost. 
In my final chapter, I review my findings and propose suggestions for future research in energy policy dynamics. 


\section{Chapter 2. Energy Policy Development in the European Union and Lithuania}

\section{Introduction: Common Energy Policy - A Consistent but Unrealized Objective Throughout the Formation of the EU}

Energy security has long been a primary policy interest of the EU as well as a motivating factor for states to join and actively engage with the Union. This chapter will review the formation and expansion of the European Union and discuss how joining the EU impacted Lithuania's energy policies. In the first part of this chapter, I review the history and expansion of the European Union and the development of the EU's energy policies. In the second part of this chapter, I briefly review Lithuania's history and its road to independence and eventual inclusion in the European Union.

For years the EU sought but failed to define a common energy policy due to opposition from member states. The European Commission has been keen on playing a dominant role in energy security, but often received opposition from member states. Consensus among EU member states is difficult to attain due to the diversity of member state's energy sources, as well as varying priorities regarding environmental and energy policies. The EU's energy policy, or lack thereof, has been studied by many scholars who review the complexity of the EU and discuss the reasons for why it has been so challenging to agree on a common energy policy. For example, Perez, Scholten, and Stegen (2019) note that Germany and Denmark promote renewable energy while Poland actively resists. Most EU members from the former Soviet Union satellite states focus on diversifying their gas supplies to avoid possible supply disruptions from Russia hence climate change and, as a result, promotion of renewable energy has not been a priority for them (Perez, Scholten, and Stegen 2019, 2). Hence different EU members seek or resist common EU energy policy for different reasons. 
The impasse over European energy policy began to change after 2004 when new members from central and eastern Europe joined the EU. Once in the EU, most of these new members started advocating for a common energy policy emphasizing energy security (Toson, Solorio 2011, 4). In fact, energy security and national security were the principal reasons that caused Lithuania to pursue membership in the EU in the first place. Ramunas Vilpisauskas (2013) noted that Lithuania has actively pursued energy security and Eastern neighborhood policy $^{2}$ from the very moment of EU membership (Vilpisauskas 2013, 132).

\section{Coal and Steel: Forging a New Union Through Economic Cooperation (1951)}

After the Second World War, Germany's infrastructure, economy, and reputation were in ruins. Although Germany and France had been rivals, French Foreign Minister Robert Schuman realized that the traditional French approach towards Germany, which had been based on constant competition, had to change. In addition, US Secretary of State Dean Acheson recognized that only France could reconcile West Germany with Western Europe and made a personal appeal to Schuman to do so (Dedman 1996, 58 - 60). Initially, Schuman proposed the pooling of coal and steel production and, after long negotiations, his proposal resulted in the signing of the Treaty of Paris in 1951 by France, Germany, Belgium, the Netherlands, Luxembourg, and Italy. The treaty established the European Coal and Steel Community (ECSC) (Dedman 1996, 57). The newly created ECSC had four institutions: The High Authority, the Special Council of Ministers, the Common (Parliamentary) Assembly, and the Court of Justice.

The High Authority, the predecessor of the EU Commission, consisted of nine members who served six years. Jean Monnet was the first president of the High Authority. Eight of these

\footnotetext{
${ }^{2}$ Eastern neighborhood policy is a tool of the EU to seek ties with the non-member states in the east and south of the EU.
} 
members were designated by the governments of the member states acting together, and the ninth was elected by the original eight members (Dedman 60, 2009). The High Authority regulated coal and steel markets and issued binding decisions for the member states. In 1958 the High Authority become the European Commission, but the main principles established by the High Authority remained the same (Liesbet 2002, 38).

The High Authority's actions were restricted by the Special Council of Ministers (since 1993, the Council of the European Union or just the Council), consisting of the Foreign Ministers and the Economic Affairs Ministers of the member states, who were empowered to pass laws concerning national economic policies, thus the Council represents the interests of the member states (Spinelli 1957, 56).

The Common (Parliamentary) Assembly, which consisted of delegations of member states' national parliaments, originally had a consultative role (Evans, Silk 36, 2008). Over time it put the issue of a common market on the political agenda and argued for further European integration (Salm 2017). The Common Assembly had the power to dismiss the Commission in a vote of censure by a two-thirds majority, otherwise the Common Assembly's power was limited.

The Court of Justice (or European Court of Justice, ECJ) is responsible for resolving controversies that arise between the High Authority and the Common Assembly (Pella 1957, 139). The ECJ also investigates possible breaches of treaties and imposes penalties on those who violate EU law or fail to enforce binding legislation (Sweeney 2014, 128).

At its creation, the High Authority was the most influential ECSC institution. Jean Monnet, the head of the ECSC planning organization, proposed the concept of the High Authority as a supranational body to run the ECSC. Monnet became the first President of the High Authority, and many scholars (Alina Kaczorowska 2010, Trygve Ugland 2011, Troitiño, 
David Ramiro 2017) credit him as a founding father of the European Union. Monnet envisioned the High Authority as a small and informal institution that would provide policy direction to the ECSC. Almost immediately after its founding in 1952, the High Authority expanded its responsibilities and organizational structure (Peterson, Shackleton 2002, 40). The High Authority's expansion was linked to and contributed to the the ECSC's economic success, which by 1954 was trading coal, coke, steel, pig iron, and scrap iron at levels that exceeded original limits set by High Authority (Kaczorowska 2010, 8). In effect, the High Authority had laid the groundwork for the establishment of policies centered on steel production. This task required an expanding bureaucracy, which Monnet did not favor and prompted his resignation from the Presidency before the end of his term (Peterson, Shackleton 2002, 73).

The purpose of the High Authority was to put the Paris Treaty economic arrangements into effect, and the Authority's decisions were binding in that regard, creating a version of corporatism. Although on some issues the High Authority had to consult a committee comprised of an equal number of producers, workers, and dealers, it could ignore the committee's advice with echoes of state corporatism (Panhuys, Brinkhorst, Maas 1968, 663). What marked the ECSC as unusual was that it was a creation of multiple states, which was reflected in the High Authority's answering to the Parliamentary Assembly (also known as the Common Assembly). The Parliamentary Assembly could remove members of the Authority by a two-thirds vote, but besides that it had no other substantial powers (Dedman 1996, 68). According to Iris Glockner and Berthold Rittberger (2012), the Treaty of Paris and creation of the High Authority as a supranational organization was the first international treaty of its kind in which the member states agreed to give up their sovereignty. 
The creation of this supranational organization after the Second World War created a unique geopolitical situation in the region. France feared a repeat of possible aggression from Germany, and Germany and Italy sought to reconstruct their shattered economies. Most agreed the war itself was in part brought on by the onerous terms of surrender of WWI and the shattered world economy that followed in the 1930s. To avoid a repeat of the economic downturn of the 1930s, the ECSC created a single market for coal, steel, rubber, and scrap metal, ensuring that each participating country would mutually benefit from trade and development of these commodities, which was sold as a central perk of membership in the ECSC (Dedman 1996, 62). Some believed that France satisfied their national interest to control Germany's resources and industrial capacities in a diplomatic way, while Germany was able to restore its image on the world stage while pursuing economic recovery (Berend 2016, 86, 87). Like Germany, Italy joined the ECSC to dissociate itself from its fascist past and rebuild its economy, which was the weakest among the six members (Pinder, Usherwood 2014, 13). Similarly, the Benelux countries joined for both political and economic security reasons (Berend 2016, 88, 89). While France was not as open to the idea of a general common market as the rest of the ECSC, they too satisfied both political goals and economic security needs vis-à-vis such arrangements (Roy 2012, 51).

France, Germany, Italy, and the Benelux countries were uncertain about the new experimental union. Still, the countries devastated by two world wars bought into the new ideas and institutional arrangements in search economic stability (Cairney, Studlar 2013, 175). However, the idea of unified Europe was not new. European countries have been searching for the political union for centuries, but these hopes remained unfulfilled due to the fact that most “endeavor[s] to restore political unity [were] by conquest" (Battaglia 1957, 3). 
If the Treaty of Paris and the creation of the ECSC set the stage for the future pursuit of a closer union between European countries, the varied success in initiatives that followed demonstrated the difficulties of selling the idea of such a union. In 1954, the French National Assembly rejected a treaty that would have created a European Defense Community (EDC) scuttling the idea of a common European military force, no doubt due to ideological opposition and the strength of national identity. The Venice meeting of May 1956 was a bit more successful: ECSC members agreed to establish a general common market via the creation of the European Economic Community (EEC) that would abolish restrictions on international trade among member states. They also created the Atomic Energy Community (Euratom) (Roy 2012, 57).

The Euratom treaty came into existence, in part, because ECSC members realized that future energy independence lay in the nuclear energy sector. Thus, the treaty aimed to develop the peaceful application of atomic energy (Allen 2017 March). According to the treaty, establishing the European Atomic Energy Community would lead to a "powerful nuclear industry which will provide extensive energy resources, lead to the modernization of technical processes and contribute ... to the prosperity of their peoples" (Treaty establishing the European Atomic Energy Community Euratom). The Euratom treaty is like the EEC treaty in its institutional design: Euratom is governed by a Council, Commission, and the European Parliament, and is supervised by the Court of Justice and the Court of Auditors. The European Atomic Energy Community never merged with European Union, but it shares the same institutions (Treaty establishing the European Atomic Energy Community Euratom). Although the Euratom treaty was signed in parallel with the European Economic Community (EEC) treaty 
in Rome, the EEC treaty is much more important and is referred to as the Treaty of Rome (Pinder, Usherwood 2014, 12).

The main objectives of the Treaty of Rome were to eliminate customs and duties between the member states, establish common customs, tariffs, and commercial policies towards nonmember states, and to remove obstacles of the free movement of people, services and capital. The Treaty of Rome established common agriculture, trade, and transport policies, in effect widening the rules that underlay the policy equilibrium among member states and extending their application to members' dealings with non-member states. By signing the Treaty of Rome, Belgium, Germany, Italy, France, Luxemburg, and the Netherlands agreed to abolish restrictions on international trade through common trade policy, ensuring balanced trade, fair competition, and reducing the economic and social differences between different EEC regions (Treaty of Rome EEC). Tariffs and quotas on trade between the member states were removed in different stages between 1958 and 1968, and industry positively responded to these changes. As a result, trade across the borders of the member state countries kept increasing (Pinder, Usherwood 2012, 57). Through the Treaty of Paris, ECSC members accomplished the desired peace in Europe, but the Treaty of Rome went one step further towards full European integration with its specific focus on developing a common market. The Treaty of Rome and EEC establishment opened new trading possibilities beyond coal and steel and initiated some structural changes, such as granting more power to the Council of National Ministers as the legislative body of the EEC and taking away some powers from the High Authority. ECSC member states became less skeptical of this new union when it proved to be beneficial economically. The change in elite political opinion towards European integration allowed for some change, however, national level institutional constraints made dramatic change hard to achieve. 
A third adjustment to the ECSC involved the Treaty of Merger, adopted in 1965. This treaty was intended to bring to together the three Eurpoean institutions, ECSC, EEC and Euratom. The idea of a merge of these institutions was not new; in fact, discussions about institutional unification emerged soon after the implementation of the Treaties of Rome in 1958 and got on the agenda in 1960 (Lauresen 2012, 77). The Treaty of Merger was signed at an Intergovernmental Conference (IGC) on April 8, 1965 and came into force in 1967 after all the member states ratified it (Lauresen 2012, 78). However, the agreement on the Merger treaty was not reached without obstacles.

Before joining the ECSC, each country had its political institutions, and these institutions impacted the member countries' stories in the ECSC and later EU. According to North and Thomas (1973), the new institutional arrangements would not be set up unless the private benefits of the new institutional arrangements exceeded their costs. In the case of the Treaty of Merger and further EU enlargements, the current members of the European community agreed to alter their countries' institutional structure only when these changes were in their economic interests.

Etienne Hirsh, the President of the Commission of Euratom, suggested creating a single executive, which "would be an important step towards the formation of the United States in Europe" (Lauresen 2012, 82). The vice president of the High Authority of the ECSC and President of the Commission of the EEC supported this idea, arguing that a single executive would ensure cohesion, coordination, and efficiency (Lauresen 2012, 85). France was reluctant to support the merger of the executive institutions, due in part to the objection of its new president, Charles de Gaulle. De Gaulle, in contrast to his predecessors, did not like the federal elements of the emerging European Community and made clear his intentions to use the 
Community to advance French power and leadership. De Gaulle also vetoed negotiations for Denmark, Ireland, Norway, and the UK to join the EEC and fomented a breakdown of negotiations over the Common Agricultural Policy which led to "the empty chair crisis" when he forbade his ministers from attending Council meetings in the second half of 1965 (Pinder, Usherwood 2014, 16). France was not the only member that questioned the merger of executive institutions. Luxemburg wanted to solve enlargement and common agriculture issues before the merger, and together with France abstained from voting in favor of the merger of executive institutions (Lauresen 2012, 87).

The merger was an effort to rationalize the institutional infrastructure that supported the increasingly complex and fractured policy and political equilibrium put into place by the ECSC, ECC, and Euratom arrangements. Still, it is important to emphasize that while the Treaty of Merger established a single Council and single Commission for all three European Communities (Euratom, ECSC, and EEC), it did so without merging the actual bodies into one entity. In addition, the member states agreed that if any of them believed that a discussed issue had a crucial importance to a member state's self-interest, negotiations had to continue until a uniform solution was reached (the Luxemburg Compromise of January 1966). Pinder and Usherwood maintain that the Luxembourg compromise should really be called the Luxembourg "veto," because for two decades any member could veto a vote if the vote did not have unanimous support (Pinder, Usherwood 214, 16). The compromise was due to the tug of nationalism and a fear of losing national identity, concerns which were most obvious among the French, but which were just as important to the smaller states as well. National interest and economic interest encouraged the European countries to cooperate and create the ECSS, national interest also encouraged more members to apply for membership in the EEC. 


\section{A. Western Expansion - First Enlargement (1973)}

In 1973, Great Britain, Denmark, and Ireland joined the European Community (Pinder, Usherwood 214, 18). These occurred in part because of the Luxembourg Compromise, as Britain and Denmark were initially suspicious of the supranationalism of the communal ideal, but perceived the Luxembourg Compromise as an opportunity to maintain their sovereignty within the framework of cooperation (Dinan 2012, 127). Another important change that occurred during the "Luxemburg compromise era" was the start of direct elections to the European Parliament. Michael Palmer (1981) calls this event revolutionary because direct élections offered citizens a voice in shaping and executing the European Community's policies (Palmer 1981, 2). Beginning in 1979, citizens from the nine European Community countries elected 410 members to represent them in the European Parliament. Direct elections allowed the European Parliament to claim that it was the only institution that served as the voice of the electorate.

Except for the British and French governments, the European Council and the national governments all agreed on direct elections for the EP. The British and French objections were due to worries over a significant growth in the Parliament's power (Palmer 1981, 6). However, in 1975 the Parliament also gained some important budgetary powers including the right to reject or amend EC budget within certain fixed limits. The European Parliament's rights were expanded even more in 1980 when the European Court of Justice ruled that the Council could not adopt Community legislation before receiving the Parliament's opinion (Shackleton 2002, 98).

Before Great Britain's membership, France was the most powerful member in the Community, hence de Gaulle's ability to put the Community's future into jeopardy during the empty chair crisis. The membership of Great Britain, Denmark, and Ireland brought new challenges and new opportunities. Great Britain was now the most powerful member and was led 
by Conservative prime minister Margaret Thatcher. Thatcher tried to block much of the Community's business until 1984 when she secured an agreement to reduce Britain's high net contributions to the Community's budget (Pinder, Usherwood 2014, 18).

In 1985, Jacques Delors of France become the President of the European Commission and once again tried to move the Community towards federalism. Delors visited each member state to find out which projects would likely be accepted by all the members. Delors focused on the issues of a single market, single currency, common defense policy, and institutional reform (Pinder, Usherwood 2014, 19). Despite other disagreements, member countries reached consensus on the single market. This decision, supported by dynamic firms and business associations, led the Commission to draft a proposal of the single market, which was presented to the European Council in 1985 (Pinder, Usherwood 2014, 20, 21).

This proposal, called the Single European Act (SEA), reformed the Treaty of Rome, and paved the way for the creation of the European Union. The Single European Act, signed in 1986, was a compromise between Eurosceptics and proponents of an even more integrated European Union (Dinan 2012, 125). The SEA ended the deadlock caused by the Luxembourg compromise by authorizing qualified majority voting in the Council. This change allowed Community members to reach decisions without spending endless time bargaining with holdouts (Barnes \& Barnes, 1995, 32).

The Single European Act also granted the EU Parliament equal rights with the High Council by requiring Parliament's approval for treaty ratification and association agreements. Each of the subsequent treaties such as the Treaty of Maastricht, the Treaty of Amsterdam, the Treaty of Nice, and the Treaty of Lisbon gave more powers to the EU Parliament (Corbert 2011, $3,5)$. 
Campos, Coricelli, and Moretti applied synthetic counterfactuals method (SCM) to estimate the benefits from joining the EU in terms of economic growth and productivity that came with 1973 enlargement. Their findings suggest that Denmark, Ireland, and UK's GPD would have been considerably lower in these countries if they had not joined the European Community in 1973 (Campos, Coricelli, Moretti 2016).

Ireland applied for the membership in the European Community expecting to benefit from the Common Agriculture Policy, but despite the help from the EC, employment in the agriculture sectors continued to decline. Yet, the membership in the EC brought a substantial increase in employment in foreign-owned manufacturing industry, and the jobs in this sector expanded by almost 40 percent between 1973 and 1980 (Barry 2003, 401).

After the passing of the Single European Act in 1986, membership in the European Union provided member countries political role and authority to define a European policy agenda (Anderson, Reichert 1995, 238).

According to Michael Burgess (2000), in the mid-1980s, members of the Community realized their declining ability to compete in domestic and world markets with strong competitors such as the United States and Japan. The newly industrialized economies of Asia also posed a threat to the member states' economies (Burgess 2000, 157, 158). Burgess argues that member states elevated domestic priorities to the EC level. For example, French president Francois Mitterrand was concerned about his declining popularity at home, and Britain was trying to solve internal budgetary problems. Like Monnet and Shuman, Mitterrand was a federalist and believed in the European Political Community in the way his predecessors did (Burgess 2000, 157, 160, 161). 
B. Southern Expansion \& Structural Changes - Second and Third Enlargements (1981, 1986)

After the first enlargement, Greece joined the EC in 1981 and Portugal, and Spain expressed an interest in joining the Community. Albeit with mixed feelings on the domestic front, Greek public opinion towards the process of European integration was mostly negative. According to Nikos Frangakis and Antonios Papayannides (2003), anti-European and antiAmerican feelings reigned among large segments of elites and the public, with a few notable exceptions. The leader of the Conservative/Nea Dimocratia party, Costas Karamanlis, openly considered integration into the Community arguing that Greece belongs to the Western Europe. After some time, the ruling Socialist/PASOK party also adopted a pro-European agenda and discussed Greek accession to the Community. At the end of the 1990s, membership in the Community was seen as Greece's gateway to modernity and stability, as well as a potential source of financial assistance for building infrastructure (Frangakis, Papayannides 2003, 166). Thus, up until the financial crisis of 2008 , Greece has enjoyed the policy equilibrium provided by the EU policies.

In contrast to Greece, Portugal and Spain were initially more enthusiastic about prospective membership. Portugal requested membership in 1977 when the country was still undergoing a process of democratic transition. Pro-European parties had been winning elections and enjoying public support and had revised a newly drafted Constitution to further their application. The Portuguese hoped that membership in the European community would help them to achieve both political and economic stability, although the former seemed to be at the forefront (Seabra 2003, 355, 356). After the long rule of dictator Antonio de Oliveira Salazar, Portugal tried to catch up with the Western democracies, and joining the European Union was a logical choice driven by self-interest. 
Similar to Portugal, membership in the European Community was one of Spain's longterm political objectives. According to Felipe Basabe Llorens, almost all political parties and many different societal actors supported Spain's entry into the European Community as means of gaining access to democratic institutions and habits (Llorens 2003, 185). Spain was the only country that joined the EU after 1958 whose political elite and general public were in favor of the integration. European membership provided a great opportunity to recover its lost place in Europe and get rid of institutional elements of Franco dictatorship (Morata 2013, 134). Spain's membership in the EU yield positive results: Spain was able to decentralize its political institutions, and before the global financial crisis Spain was one of the EU members that experienced the highest economic growth (Morata 2013, 135).

The roots of the European Union lie in the coal and steel community, but the successes in this sphere of industry and further expansion of European Community inspired creation of other common policies such as the common agriculture policy (CAP), cohesion policy, agriculture, and energy environmental policies, common fishing policies, etc. CAP policy is usually called the engine of European integration and the most controversial of the EU policies (Knudsen 2009, 4). Acknowledging the EU member countries concerns regarding supranational institutions it is a bit surprising that CAP involved to be the most dominant policy in the EU. In addition, negotiations regarding the CAP policies began in the 1960s when European Community still was in the nascent stage (Knudsen 2009, 2).

The same cannot be said about the energy and environmental policies in the EEC and in the European Union which were very hard to achieve. Environmental policy did not evolve as easily as agricultural policy. According to Andrew Jordan and Camilla Adelle (2005), environmental policy was not significant during the EC's first fifteen years, thus "it is 
inappropriate to speak of an institutionalization process in terms of environmental protection (Jordan, Adelle 2005, 24). The situation regarding the environment changed during Paris Summit Conference in 1972 when members states asked for a blueprint for an official EC environmental policy (Jordan, Adelle 2005, 24). It still took decades for the energy policy to become a priority for the European Union.

Spain and Portugal joined the Community just before the adoption of the Single European Act, which changed unanimous voting in the Council to qualified majority voting. This modification in voting procedure led to the Treaty of the European Union or the Treaty of Maastricht, which was signed in February of 1992, and entered into force in November of 1993. The Treaty of the European Union (TEU) was based on the existing European Communities (ECSC, EEC, and Euratom), and was intended to bring the European people "to ever closer union" (The Maastricht and Amsterdam Treaties) by establishing an economic and monetary union. The second pillar established a common foreign and security policy (CFSP), which replaced the provisions of the Single European Act and allowed member states to take joint action in the field of foreign policy. In the foreign policy field, almost all decisions were required to have unanimous votes. Finally, the third pillar was based on justice and home affairs (The Maastricht and Amsterdam Treaties).

The TEU did not change the Community's institutions, but it did usher in some important reforms. Modifications and closer European integration brought some concerns among the member states. According to Bernhard Wessels and Richards S. Katz (1999), after the Maastricht Treaty, the consequences of European integration were perceived as threatening to the national identity of the existing member states. It is possible that EU citizens and national governments were concerned about deeper political integration through institutions and monetary union 
(Wessels, Katz 1999, 5). However, the ability to directly elect members to the EU Parliament assuaged some of the sovereignty concerns and EU citizens' former inability to voice their concerns to EU.

After the first direct elections to the European Parliament, it decided to hold an informal "vote of confidence" on each incoming Commissioner. The Maastricht Treaty formalized the Parliament's functions, giving it the right to be consulted on the choice of the Commission president and introducing the right to veto a whole Commission. In addition, since the Treaty of Maastricht, the Commission had to be approved by most of the EP members. The term of the Commissions was also changed to five years to correspond with that of the Parliament (Hix, Noury, Roland 2007, 15).

The Maastricht Treaty slightly changed the institution of the European Commission and European commissioners, but the main principles of the EU Commission remained the same: the European commissioners themselves must be independent and should not take instructions from any governments or institutions. The Commission shall promote the general interest of the European Union (Nugent, Rhinard 2015, 9, 15). As independent members, who must advocate for the EU interest, the Commissioners have an opportunity to set energy agenda. Each EU member state has a commissioner who is usually a senior, former national politician. Since the Maastricht Treaty of 1992, the Commissioners are appointed for five-year terms (Nugent, Rhinard 2015, 10). The Commission has much in common with some European and even U.S bureaucracies. Similar to U.S bureaucracy, the Commission's power is divided among various branches of the government and between different territorial levels. Like French bureaucracies, the Commission is divided into several categories: those which provide executive work, secretarial work, and basic custodial work (Liesbet 2002, 39). 


\section{Northern Growth - Fourth Enlargement (1995)}

It seems that once the members of the European Communities achieved their "even closer union," the popularity of the newly formed European Union slowly began to decline. Nonetheless, in 1995 Austria, Finland, and Sweden joined the EU. While the Mediterranean countries joined the European Community to reunite with the established European democracies after the fall of their authoritarian regimes, the Nordic countries and Austria had different reasons for joining the EU. For Austria, foreign policy was a key concern. Austria preferred to maintain neutrality during the Cold War, caucusing with countries like Switzerland, Sweden, and Finland. The changing economic and political situation in the 1990s caused Austria to reconsider its attitudes towards the European Union (Holl, Pollack, Puntscher-Riekmann 2003, 337).

After the collapse of the Soviet Union and the emerging war in the former Yugoslavia, Austria's elite realized that membership in the EU would ensure Austria's security. Before the accession referendum, most of the political elite supported membership except right-wing populists, the Green Party, and the Austrian Communist Party (Holl, Pollack, PuntscherRiekmann 2003, 339). Thus, it is not a surprise that with so much backing, the majority of the voters were in favor of Austria's membership in the EU.

Similar to Austria, Finland and Sweden decided to apply for EU membership after years of neutrality. The political elite in both countries supported membership, but a few groups had expressed concern. The Farmers Union and rural voters opposed Finish membership in the campaign preceding the referendum because they believed that membership would pose a threat to their livelihood (Tiilikainen 2003, 150). Sweden joined the EU mostly for economic reasons, since Sweden had a long association with Western Europe. In fact, Sweden joined the Common 
Market economically before its membership to the EU was formally approved (Johansson 2003, 369).

Norway and Switzerland considered membership to the European Union but withdrew their applications due to a lack of public and governmental support. It is often true that once a country joins the EU, public support for their membership begins to decrease. Declining support for the EU was noticeable in member states from the founding members even before the TEU. For example, Great Britain and Denmark opted out of participating in the single currency. In addition, Denmark rejected the Maastricht Treaty in their first referendum, and French voters just barely supported joining the EU in their referendum (Pinder, Usherwood 2014, 26). After overwhelming support in the beginning, Spain's membership at the EU experienced a decline in support as a result of conflicts over fisheries, industrial reconversion, reform of olive oil tariffs, and other issues (Llorens 2003, 184). Enthusiasm possessed by Austrian citizens in the EU accession referendum declined after Austria had to adopt restrictive budget policy to meet the EU requirements for the Economic and Monetary Union (EMU) (Wessels, Maurer, Mittag 2013, 348).

\section{From One Union to Another - Fifth and Sixth Enlargements (2004)}

The European Community's institutions had been incrementally changing since the treaty of Paris, but the most substantial changes occurred in 2004 when ten countries (Czech Republic, Cyprus, Estonia, Latvia, Lithuania, Hungary, Malta, Poland, Slovenia, and Slovakia), eight of them from the former Soviet Union, joined the EU in what was the largest case of EU enlargement. Bulgaria and Romania joined the EU several years later in 2007. Some authors suggest that former communist states were eager to join the EU and "catch up" with the rest of the Europe, but others argue that the post-communist countries were skeptical of a new union. 
Elizabeth Radziszewski (2013) suggests that post-communist countries tried to distance themselves from the Russian sphere of influence and for this reason they undertook a series of administrative and legal reforms to bring their countries closer to the Western European nations (Radziszewski 2013, 15). Radziszewski argues that Eastern European countries are more likely to support the EU when their GDP is lower, as they will reap stronger economic benefits from integration (Radziszewski 2013, 15). Zaneta Ozolina argues that Lithuania, Latvia, and Estonia wanted to join the EU for political reasons, primarily as a means of protecting their newfound sovereignty and to gain influence in the international arena as members of a larger community with similar goals (Ozolina 2003, 206). The EU Commission, worried by the growth of pockets of euro-skepticism in member states, hoped that the new member states from Central and Eastern Europe would bring euro enthusiasm.

The European Union is an example of successful cooperation among former rivals such as France, and Germany. Inspired by the early success, other European countries expressed interest in joining the European Union, but as my discussion above suggests, the path to EU integration for many countries has been long and challenging. The pursuit for the common agriculture policy resulted an "empty chair crisis," which was later resolved by the Luxemburg Compromise. It also took forty years for the EU members to agree on EU monetary policy, and it took decades for the former Soviet Union satellite countries to "catch up" with the rest of the Europe. It is possible to conclude, that EU members reach consensus on certain policies, when these policies were beneficial for them.

However, a common energy policy (similar to European Defense Community policy) did not come to fruition because EU members refused to jeopardize their sovereignty. Energy policy is also closely related with national sovereignty as each individual country have different energy 
mixes and different relations with their energy supplies. But Lithuania is one of the EU members that has consistently advocated for a common energy policy. Therefore, in the following section I provide a historical context for Lithuania to help to understand its energy policy development and the reasons why EU membership was so crucial for this Baltic state.

\section{Historical Context of Lithuania}

Today, Lithuania is a semi-presidential republic with a separation of powers between the popularly elected President and the Parliament (Seimas). The president of Lithuania is mainly responsible for foreign and defense policies. The president also has powers to confirm ministers, sign laws passed by Seimas, and to lead the military forces of Lithuania. The Lithuanian Seimas participates in conducting foreign policy by using its powers in international treaty ratification (Vilpisauskas 2013, 128). The Lithuanian Seimas is elected by using a mixed electoral system (Ferrara, Herron 2005, 5).

The Seimas consists of 141 members. In single-member constituencies, members are elected in two-round elections: if more than 40 percent of the electorate vote during the first round, and one of the candidates receives more than 50 percent of the vote, that candidate wins a seat in Seimas. If neither of the candidates receive more than half of the cast votes, a runoff election is held after two weeks, where the two front-runners compete for the seat (Clark 1994, 46; lrt.lt 2020).

Since the $13^{\text {th }}$ Century, much of Lithuania's history has been shaped by its relationship with Russia, and often that relationship was either tense or hostile. The Lithuanian empire was larger than the joint principalities of Muscovy (current Russian territory), but constant battles with the Teutonic Order and the Russians weakened the Grand Duchy of Lithuania. Seeking collaboration and protection, Lithuanian Prince Jogaila accepted the Polish crown and formed an 
alliance with neighboring Poland. The alliance granted Lithuania more military power, but as a pre-condition of this alliance, pagan Lithuania had to convert to Christianity. In 1569 Lithuania become a formal subordinate of Poland and lost its autonomy for centuries (Mole 2012, 24).

Inspired by the French Revolution and American Constitution, an alliance of Lithuanians attempted to form a Commonwealth and drafted the first modern written constitution in Europe in 1791. But internal disfunction and unsuccessful wars with the Russian Empire wiped the Commonwealth from the map in 1795. The Russian Empire applied Russification policies in the occupied lands by banning Lithuanian books in the Latin script, yet these Russification efforts only galvanized Lithuanian resistance. Materials printed in Lithuanian were published in secret and several unsuccessful revolts were organized. Lithuania finally declared its independence in 1918, however, this independence was short lived and in June of 1944 Lithuania lost its independence to the Soviet Union. The Soviet Occupation resulted in mass deportations and substantial population loss (Mole 2012, 28-49). The majority of Lithuanians only reluctantly participated in Soviet life, but the ever-present Communist party served as a constant reminder of the occupation. Gorbachev and his policies created an environment for Lithuania (and for the other Baltic states) to question the legitimacy of the Soviet occupation.

In 1987, dissident and political groups outside the official Communist Party of Lithuania started to emerge. The first one to emerge was the ecological movement that had obvious nationalist agenda: to counter Moscow's destruction of Lithuania's environment. After the nuclear accident at Chernobyl the ecological movement of Lithuania targeted Ignalina's nuclear power plant as an 'implant' of the Soviet Union that endangered the Lithuanian people and the environment (Olcott 1990, 33). The early statements of the Lithuanian ecological group 
regarding Ignalina's nuclear power plant became problematic years later when Lithuania applied for the EU membership and had to decommission the Ignalina nuclear power plant.

The Sajudis movement emerged in 1988, initially aimed at wresting more autonomy and freedom for Lithuania from the Soviet Union. Soon, Sajüdis' ideas become more radical as it started arguing for Lithuania's independence. Sajūdis elected Vytautas Landsbergis as its president who eventually led Lithuania to independence. The secretary of Lithuania's Communist party, Algirdas Brazauskas, was hesitant at first about the possibility that Lithuania could break away from the Soviet Union, but he later left the Communist Party and supported Lithuania's independence (Olcott 1990, 34).

Lithuanian independence was not welcomed in Moscow, and Gorbachev decided to enforce an energy embargo against it. Sajūidis activists feared but anticipated the possibility of an embargo in retaliation (Olcott 1990, 42). Natural gas and oil supplies were turned off in April 1990 and Lithuania was given 48 hours to rescind their declaration of independence (Dahlburg, Schrader 1990). Lithuania did not withdraw its claims of independence, and Russia extended its embargo to certain shipments of food, and metal industrial parts. The newly created Lithuanian government was not overly concerned about the food embargo since Lithuania produced enough meat and dairy products, but gas and oil embargo left an enduring impression on Lithuanian government and people (Imse 1990).

In light of this historic context, Lithuania has always been suspicious of its neighbor to the East (from Imperial Russia, to the Soviet Union, to the present-day Russian Federation). As Ligia Istrade (2012) notes, Lithuania and other Baltic states were interested in joining the European Union even before European Union was formally set up in 1993 (Istrade 2012, 46). Lithuania's policy makers from the major political parties promoted the EU membership to the 
Lithuanian public. On the day of the referendum for the EU membership, Lithuanian Prime Minister Algirdas Brazauskas cancelled a planned trip to Estonia to urge people to vote for the EU membership. The major stores in Lithuania were selling chocolates and beer for one cent to the customers who presented a proof that they voted in the referendum (an 'I voted" sticker) (Referendum in Lithuania looks set to ratify EU membership, 2003). After the successful referendum, Lithuania joined the EU, and started advocating for a common EU energy policy. Hence, Lithuanian policy makers were pleased with the Lisbon Treaty.

The Lisbon Treaty introduced the obligation of co-operative defense stating that the member countries are obliged to offer support though all possible means to a member which falls victim to aggression (Istrade 2012, 48). The most important achievement for Lithuania was that the Lisbon Treaty also addressed energy security and energy policy. Energy security has been important issue not only for Lithuanian policy makers, but also for the general public. Based on 2013 data, $81,8 \%$ of respondents acknowledged that energy independence is an especially important issue for them, and in 2017 this number rose to $90 \%$ (Leonavičius, Juozaitis, Genys 2019, 106).

The European Union played a significant role in the development of Lithuania's energy policy. EU specialists required Lithuania to close Ignalina's nuclear power plant, and this demand came as a surprise to the Lithuanian government. EU representatives argued that Ignalina's nuclear power plant reactor had the same designe as Chernobyl's and was, therefore, had be considered unsafe. According to Jurgis Vilemas (2010), EU membership was the most important political priority for Lithuania, and none of the political leaders could resist the unconditional requirement to close the nuclear power plant if it secured the EU membership. 
After negotiations, it was decided that the first reactor would be closed in 2004, and second in 2009 (Vilemas, 2010, 40).

After the closure of Ignalina's nuclear power plant, Lithuania become even more dependent on Russia’s natural gas to generate electricity (Mišík, Prachárov 2016, 586). Energy prices for Lithuania have increased since 2000 and took a steep increase after it joined NATO and the EU. The price of gas in 2007 was 2.4 times higher than in was in 2005. In 2013, Lithuania paid one of the highest gas prices in the EU, even higher than Latvia and Estonia (Mišík, Prachárov 2016, 591).

Despite high energy prices, EU membership helped Lithuania to break away from Russia's influence. The Lisbon Treaty gave Lithuania a basis to negotiate energy projects as a part of the EU. After the Lisbon Treaty, the Energy Council drafted conclusions on strengthening the external dimension on of the EU energy policy as the Council was looking for a cooperation between the member states and the EU this sentence is not clear. In the Energy 2020 Strategy, the Commission emphasized the need for loyalty between the EU and its member states and stated that the Union can more effectively defend energy security in Europe, than separate states can individually (Jatkauskaite 2013, 41).

As an EU member, Lithuania had the opportunity to chair the Presidency of the Council starting on July 1, 2013. During the six-month term, Lithuania advocated strongly to increase energy security within the EU, strengthen EU relations with Eastern Partnership countries (EaP), strengthen the Baltic Sea Strategy, and to effectively manage external borders (Vilpišauskas, Vandecasteele, Vaznonytė 2013, 12, 14). According to Vilpišauskas, Vandecasteele, Vaznonytė, Lithuania has been the outspoken advocate of energy security during the negotiations of the Lisbon Treaty, and argued for the energy security provision. Lithuania also supported the Baltic 
Energy Market Interconnection Plan (BEMIP) as a tool to coordinate energy projects with the eight member states located along the Baltic Sea (Vilpišauskas, Vandecasteele, Vaznonytė 2013, 28, 29).

After the beginning of Lithuania’s Presidency, Russian authorities started putting pressure on EaP countries and threatened to manipulate energy supplies. Subsequently experiencing pressure from Russia regarding Nagorno-Karabakh, Armenia leaders decided not to proceed with association with the EU and instead joined the Eurasian customs union. Similarly, the Ukrainian president announced his decision to suspend signing association agreements with the European Union, although Ukraine continued negotiating behind the scenes (Vilpišauskas 2014, 106).

After decommissioning Ignalina's nuclear power plant, Lithuania started taking a leadership role in the EU energy domain. According to Molis and Vaisnoras, Lithuania was eager to get involved in creating and EU common energy policy, and by doing so, enhanced Lithuania's role in EU institutions. In pursuit of common energy policies, Lithuania also emphasized fundamental EU values in the economy domain and such as the "common internal market, sustaining competitiveness, strengthening environmental requirements, and solidarity" (Molis, Vaisnoras 2010, 25).

Lithuania's pursuit of energy independence as an EU member bore some fruits, but in the beginning of 2010, when Ignalina's nuclear power plant was finally closed, Lithuania's energy dependence on Russia increased even more (Vilpisauskas 2010, 133). In time, Lithuania secured some key infrastructure development projects such as the power link between Lithuania and Sweden (NordBalt), the electricity link between Lithuania and Poland (LitPol Link), and a liquefied natural gas terminal (Molis, Vaisnoras 2010, 25). The liquefied natural gas (LNG) 
terminal in Klaipeda was built with financial support from the EU. This new LNG terminal allowed Lithuania to access EU markets (Hönig, Prochazka, Obergruber, Smutka and Kǔcerová 2019, 3). Participation in the EU also helped Lithuania to mitigate energy related disagreements with other EU members; for example, Lithuania had a mutual disagreement with Latvia over the route for the electricity power bridge from Sweden to the Baltic states. This dispute delayed the project for more than a year, but was resolved through EU involvement (Vilpisauskas 2013, 134).

The discussion above shows that Lithuania's pursuit for the EU membership and for the EU common energy policy. As the small country with no substantial natural resources of its own, Lithuania's policy makers hoped to benefit from the EU membership. Although the EU has not reached a common energy policy yet, the EU has helped Lithuania to build LNG terminal in Klaipeda and to secure electricity power link projects such as NordBalt and LitPol Link.

What follows below, is an analysis of the challenges the EU faced in developing its energy policy. EU member states have different energy mixes, but energy blockades, climate change, and pressure from new members (that joined the EU in 2004) incited the EU to finally make energy policy a priority.

\section{Analysis - Evolution of the EU Energy Policy Relative to New Member States \\ Differences in energy reserves, production capability, industrial organizations, and} dependency on imports are a few of the barriers to common EU energy policy. The 2004 Enlargement brought new opportunities and challenges for an EU common energy policy. Former Soviet satellite states argued for a more cohesive and coordinated EU energy policy that would ensure energy and national security. However, due to the number of states with competing 
energy mixes, diverse reserves, and conflicting priorities, reaching consensus in the EU has been very difficult.

Russia poses a challenge to EU energy security due to its unique and competitive worldview. According to Jonas Grätz, EU business relations are based on a "markets and institutions" approach, whereas Russia pursues a realist "regions and empires" strategy and uses economic power to reach its political goals. By strategically turning off gas exports, Russia has been successful in punishing uncooperative dependent neighbors such as Lithuania, Georgia, and Ukraine (Grätz 2011, 62, 63). For example, while new member countries in the East depend on Russian energy, France has nuclear power, Germany and Spain have substantial coal reserves, and the Netherlands have natural gas (Meritet 2007, 4768). Italy and Malta import 80-100 percent of their national demand, whereas Denmark is a net energy exporter. Poland relies on coal for up to 50 percent of its power supply, thus Poland's target $\mathrm{CO} 2$ reduction goals imposed by the EU pose a major challenge for it (Langsdorf 2011, 1, 3).

The first steps towards common energy policy were taken in the early 1990s when the Commission attempted to use structural power and involve the EU's financial capital in Russia's energy sector. However, member states rejected the Commission's efforts and established their own bilateral cooperation schemes. The Energy Charter Treaty (ECT) was drafted to stabilize and subject Russia to European jurisdiction. ECT included the political commitment to work on binding multilateral treaty which would "regulate energy investment, transport, trade, and innovation" (Gratz 2011, 64, 65). However, some EU members objected to the ECT and that gave Russia disincentives to ratify the ECT. At the same time, Russia also started viewing the ECT as an infringement of their sovereignty. The president of the EU Commission, Romano Prodi, tried to engage Russia in the bilateral Energy Dialogue of 2000 and to promote the 
ratification of the ECT, but Prodi's efforts were unsuccessful. However, Russia alone cannot be blamed for the lack of the energy related dialogue as EU member countries pursued their own interests and some states cooperated directly with Russia on energy related projects (Gratz 2011, $68,69)$.

For many years the EU neglected the topic of a common energy policy due to lack of coordination between member states and only started emphasizing energy related questions after several punctuating events. First, in the early 2000s unrest in the Middle East and a sudden rise in oil demand in China and South Asian countries caused crude oil prices to increase. A second punctuating event occurred in 2006 when Russia shut down gas pipelines to Ukraine. Since vital gas infrastructure reaches the EU via Ukraine, EU member states also experienced the reduction in available gas supplies in January of 2006 (Eikeland 2011, 32).

The Treaty of Amsterdam of 1997 was supposed to extend the creation of a more integrated Union, and the Treaty of Nice of 2004 was directly related to large-scale expansions and preparations of EU institutions to work with a large number of new member states. But neither of these two treaties addressed common energy policy (Jatkauskaitè 2013, 3, 4).

A formal commitment to move towards common energy policy finally occurred in October 2005 during an EU summit at Hampton Court. The formal proposal from the 2005 Summit was published in a March 2006 Green Paper where the Commission emphasized the need for coherent energy policy and coordination among the member states. The member-states representatives in the EU Council accepted the Green Paper proposal and backed the Commission's call for better coordination and for a comprehensive Strategic Energy Review (Youngs 2011, 43). 
A year later EU members agreed to the Lisbon Treaty which amended two fundamental treaties and expanded the constitutional basis of the EU, granting the Union more authority to address issues like energy policy. The Lisbon treaty also created an energy department which combined energy and foreign policy diplomats. Youngs argues that record high oil prices during mid-2000s, Russia's periodic interruptions of gas supplies to Ukraine, and terrorist threats that targeted energy pipelines prompted member states to push for common energy policy (Youngs 2011, 46, 47). The Lisbon Treaty created instruments to liberalize energy trade, to regulate greenhouse gas emissions, and to promote renewable energy sources of energy (Eberlein 2012, 167). According to Bukard Eberlein, early EU energy policy was a failure for several reasons, but the main reason was the lack of depth of EU institutional development to take advantage of policy windows of opportunities. One missed policy window was the oil crisis of 1973/74. (Eberlein 2012, 153). However, in the new millennium the EU Commission used global climate change and supply security to seek a common energy policy. Eberlein argues that public awareness of climate changed peaked after the documentary 'Inconvenient Truth' put climate change in the global spotlight. In addition, the U.S withdrawal from the Kyoto Protocol in 2001 provided the EU with an opportunity to show leadership in the global climate arena (Eberlein 2012, 164). Therefore, EU energy policy started to change, and countries that joined the EU during 2004 enlargement contributed to this change.

In contrast to Eberlein, Arunas Molis and Tomas Vaisnoras (2010) argue that climate change protection was not the core factor that forced the EU to seek a common energy policy. According to Molis and Vaisnoras, EU expansion and the requests of new member states, disruptions of energy supplies that effected a number of EU member countries, growing global competition for resources, and acknowledgment the need to save energy made the EU to seek a 
common energy policy (Molis, Vaisnoras 14). Regardless of the reasons, it took several decades for the EU to begin actively seeking a common EU energy policy.

It is possible that climate change, and the biggest EU enlargements prompted the EU to pursue more common energy policies. With the new members, the EU also got involved in energy disputes with the Russian gas company Gazprom. For example, it soon become clear that Gazprom was charging the Baltic states, and the other non-EU members that leaned towards West (Georgia and Ukraine), higher gas prices compared to the countries that remained friendly with the Kremlin. As the result of these price manipulations, the EU Commission opened an antitrust case against Gazprom accusing charging unfair prices to the Baltic States, Bulgaria, and Poland, as well as bullying Bulgaria to support South Stream. As the result, by May 2018, Gazprom reached the deal with the EU Commission to reform its pricing structure (Van de Graaf, Socacool 2020, 61,62). This is a clear example of how the EU helped new member states assert their independence from the former Soviet Union's sphere of influence.

The discussion above shows that in the recent years, the EU made substantial progress towards a common energy policy. Pursuit of a common energy policy was prompted by the Russian energy blockades and their impacts on the gas supply to the Western Europe. Other factors that encouraged the EU to pursue a common energy policy were the climate change, and the biggest EU enlargement of 2004, when countries from the former Soviet Union's sphere of influence joined the EU. These new countries pressed the EU to pursue the common energy policy and address their energy needs. Since Lithuania did not have substantial energy resources of its own and had to import gas from Russia, Lithuania become the biggest advocate for the EU common energy policy. 


\section{Conclusion}

For decades, the European Union did not pursue a common energy policy. The EU finally began to make progress towards a common energy policy in 2004 when new members joined the EU. The Treaty of Lisbon expanded the EU's constitutional authority, created an energy department, and empowered member states to advocate for energy issues. Discussions about a common EU energy policy were elevated to a higher level after some EU members experienced disruptions in their energy supply. Climate change and environmental concerns also played a role in the Lisbon Treaty.

Not all the EU members experienced hostile relations with Russia, but Lithuania has a history of distrust and suspicion of their neighbor to the East. Promptly after declaring independence from the Soviet Union, an independent Lithuania sought EU membership. Both the Lithuanian political elite and the general public anticipated that EU membership would ensure national and energy security for an independent Lithuania. Once in the EU, Lithuania advocated strongly for a common EU energy policy and managed to receive assistance from the EU to expand its energy infrastructure. Where EU expansions and shocks to stable energy supplies acted as punctuating events for developing a framework of a common energy policy, other global events can act as punctuating events to push energy policy towards or against particularly energy sources.

In the next chapter, I analyze energy related written questions that members of the EU Parliament submit to the EU Commission to better understand how punctuating events like the Fukushima nuclear affected that legislative body's policy development. 


\section{Chapter 3. Energy Policy Dynamics in the European Parliament}

This chapter applies punctuated equilibrium theory (PET) to the European Parliament (EP) to study whether party groupings in the European Parliament respond to punctuating events such the Fukushima nuclear accident. I study EP party groupings and their political platforms on energy and environment to evaluate how punctuating events affect the policy behavior and priorities of these party groupings.

In the first section I review PET's applications in other democratic countries and organizations by following up on my discussion in Chapter One. I conclude that PET has not been applied to studying how EP members submit questions to the EU Commission. Thus in applying PET to the European Parliament, I attempt to supplement existing literature on PET's applications outside the U.S

In the second section I overview the European Parliament and its main functions, and in the third section I discuss parties of the European Parliament and their main party groupings as well their stances on energy and environment issues.

Fourth, I investigate written questions that members of the European Parliament (MEPs) submitted to the EU Commission between 1992 and 2014. I discuss how these questions can reveal a party's preference to promote a certain type of energy, or to criticize an energy source they oppose. I analyze the importance of these questions and what these questions can reveal about the EU Parliament, MEPs, and shifts in energy policy and priorities.

In the fifth section I introduce my methodology, and in the sixth, I present case studies on nuclear, coal, shale gas (hydraulic fracturing), wind, and solar energies. In these case studies, I apply PET to the written questions that MEPs submitted to the EU Commission. I study how 
MEPs from the different party groupings perceived these energy sources and how these party groupings reacted to a punctuating event such as the Fukushima nuclear accident.

\section{Application of PET Outside of the United States}

Many researchers collect data and analyze changes in political equilibrium in various countries: Jean-Phillippe Gauvin and Eric Montpetit (2019) in Canada, Daniela Širinić and Dario Nikić Čakar (2019) in Croatia, Christoffer Green-Pedersen and Peter B. Mortensen (2019) in Denmark, Emiliano Grossman (2019) in France, Christian Breunig and Tinette Schnatterer (2019) in Germany, Zsolt Boda and Miklós Sebők (2019) in Hungary, Nir Kosti Ilana Shpaizman and David Levi-Faur (2019) in Israeli, Enrico Borghetto, Marcello Carammia and Federico Russo (2019) in Italy, Arco Timmermans and Gerard Breeman (2019) in the Netherlands, Rhonda L. Evans (2019) in New Zealand, Ana Maria Belchior and Enrico Borghetto (2019) in Portugal, Ana Maria Belchior and Enrico Borghetto (2019) in Spain, Roy Gava, Pascal Sciarini, Anke Tresch and Frédéric Varone in Switzerland, and Alper Tolga Bulut and Tevfik Murat Yildirim (2019) in Turkey. All these researchers study agenda setting process overtime based on collected overtime data on party manifestos, public opinion, parliamentary questions, primary laws, legislative degrees, etc.

Keith Dowding, Aaron Martin, and Rhona Evans (2019) apply PET in studying policy processes in Australia. They coded federal legislations (from 1966 to 2015), governor's speeches (from 1945 to 2013), opposition questions (from 1980 to 2013), media's coverage (from 1996 to 2013), public opinion (from 1992 to 2013), and high courts of Australia decisions (1903-2016). Dowding, Martin, and Evans argue that the opposition pays a disproportionate amount of attention to the economy (Dowding, Martin, and Evans 2019, 6). 
Peter John, and Shaun Bevan (2013) also employ PET in investigating the content of Acts of the UK Parliament from 1911 to 2008. In doing so, they distinguish three types of policy punctuations: procedural punctuation, low-salience punctuation, and high-salience punctuation. Procedural and low-salience punctuations occur when a large amount of legislative time is taken up to revisit and revise legislations. Usually, the wider public or even most of the policy makers are not interested in such legislation. In other words, low-salience punctuations do not show publics and policymakers interest in the issue. In contrast, issues that cause highsalience punctuations sparks interest among policymakers and wider public. Such issues are being reported in the media and attract attention of the public (John, Bevan 2013, 92, 93). John and Bevan conclude that not all punctuations are caused by public or media's interest in the issue, and that some punctuations might be procedural (John, Bevan 2013, 104).

Many researchers applied PET in investigating policy changes in multiple countries and the EU Council, but PET was not applied in studying EU Parliament and the questions that members of the EU Parliament submit to the EU Commission. PET application that I propose fills the gaps in the literature and shows how the EP reacts to the punctuating (or triggering) events such as the Fukushima nuclear disaster. In addition, PET can help to broaden discussion on the party groupings and their behavior.

\section{European Parliament}

The EU Parliament is based in three locations: Luxembourg, Brussels, and Strasbourg. The EU official seat is in Strasbourg, but most of the Parliament's activity occurs in Brussels, and most of the secretariat activity in Luxembourg (Jacobs, Francis, Corbett 2011, 34). The 751 members of the EU Parliament are elected directly by EU voters every 5 years. The EU Parliament is responsible for legislative, supervisory, and budgetary functions, passing laws in 
concert with the EU Council, deciding upon EU enlargements and international agreements, and reviewing the Commission's decisions. The EU Parliament has the power to approve members of the Commission and to force them to resign. Together with Council, the EU Parliament establishes and approves the EU budget and legislation adopted in the EU Parliament is binding on EU citizens (Overview, European Parliament, European Union). Like national parliaments, the EU Parliament is composed of different parties, but usually these political parties form right-leaning, left-leaning, radical, liberal, and the environmental party groupings.

Giorgia Delsoldato (2002) stresses that the Centre-Right Christian democratic parties united under EP's European People's Party (EPP) group, and the Left-of-center social democratic parties under the Party of European Socialists (PES) are the main party groupings in the EU Parliament. These transnational party groupings are cohesive and played a crucial role in increasing the EP's role in the legislative process. Around 1999 EPP become the largest political group in the EU Parliament and changed its name to the European People's Party European Democrats (EPP-ED) (Delsoldato 2002, 271).

The EU Parliament is the most far-reaching experiment in transnational democracy with a controversial history: some of the Member States and some political parties had opposed the creation of the EU Parliament. Members of the EU Parliament came from almost 200 political parties from the member states, but once elected to the EU Parliament almost all these members join several party groupings. The EU Parliament has gained more influence and legislative power over the years; however, not many scholars have studied EU Parliament and policy dynamics (Héritier 2017, 1-28). Most political scientists have focused on the EU Commission and the EU Council, while some have applied punctuated equilibrium theory (PET). PET has not yet been applied in studying the EU Parliament. 


\section{European Parliamentary Political Groupings}

In this section I discuss political party groupings and their attitudes towards energy policy. Energy policy is the main focus of my study because I am interested to find how much attention political party groupings dedicate to energy policy in their platforms. Most researchers agree that MEPs political parties usually vote within their EU party group (Hix 2011, Thompson 2011) but in this section I am interested to find if members of the European Parliament also submit written questions within their EU party group or whether they favor their national interests.

Political groups are crucial components to the EU Parliament and to its functions, yet political groupings have been changing over time. In addition, different researchers classified political groupings slightly differently, and their classification depends on the time of their study or the studied subject. Research on recorded roll-call votes reveal that MEPs tend to vote more along their supranational party lines rather than national lines. There is no governing majority in the European Parliament and the competition among the political groupings has been growing in the recent years (Hix 2011, 143, 144; Thompson 2011, 51).

Other research on voting-behavior also suggest that MEPs are likely to vote within the party lines and that MEPs seem likely to follow voting instructions from their political group leader (Hix, Noury, Roland 2008, 829). In 2004, the number of the member states increased from 15 to 25, and the MEPs increased from 626 to 732. Voting cohesion also increased in the enlarged EU Parliament and reinforced findings of the previous research that the EU Parliament is dominated by political parties and by left-right politics (Hix, Noury 2011, 160 172).

Other studies offer different party groupings. Simon Hix and M. Marsh examined nine party families/groupings from 1979 till 2009. These party groups were Anti-EU, the Greens, 
Radical Right, Regionalists, Radical Left, Christian Democrats, Liberals, Conservatives, and Socialists (Hix, Marsh 2011, 30). Yet in another study Simon Hix and Hoyland Bjorn differentiated six political groupings in the EU Parliament: European People's Party (EPP), Party of European Socialists (PES), Alliance of Liberals and Democrats for Europe (ALDE), European United Left,/Nordic Left, Union for a Europe of the Nations (UEN) and Greens/European Free Alliance (G/EFA) (Hix and Hoyland 2011, 139).

Emil Kirchner (1984) distinguishes seven political groupings in the EU Parliament from 1972 to 1982. They were the Socialists Group (S), Group of the European People's Party (ED), Communist and Allies Group (COM), Liberal and Democratic Group (L), Group of European Progressive Democrats (EPD), Group for Technical Coordination (GTC), and members that were not attached to any political groups (Kirchner 1984, 30). Kirchner studies how MEPs are distributed in different EU Political groupings by age, gender, and profession (Kirchner 2011, 1156).

Robert Ladrech (1996) argues that political parties and the EU Parliament become even more important after the Maastricht Treaty when EU transformed from an economic union to the political union (Ladrech 1996, 293). Ladrech pays more attention to the regional parties and pro- and anti-EU sentiment. He also stresses that the Christian Democrats (EPP) have always had a long-standing commitment to the EU integration (Ladrech 1996, 299).

Over time the Christian Democrats (who later changed their name to the European Peoples Party, EPP) has grown, and changed its character. Richard Corbett, Francis Jacobs, and Michael Shackleton (2011) studies evolution of the political groupings in the EU Parliament. Corbett et al., note that Christian Democrats perceived themselves as centrists and supported federalist ideas. Christian Democrats were represented in all six original members states and 
were the largest party in almost all their respective parliaments. Members that joined the Christian Democratic group after EU enlargements brought unique views on economic and social issues (Corbett, Richard, et al 2011, 88, 89). The other two main political groupings in the EU Parliament have been the Socialist and the Liberals, but the dynamic of these political groupings also have been changing over time.

The first political groups were founded in June 1953 and they represented the Socialists, the Liberals, and the Christian Democrats. The Socialists, and the Christian Democrats (EPP) have always been the two largest groups in the EU Parliament since the direct elections. The third large group can be identified as a Liberal Group, although the names of these Liberal groups have always been changing. Members of far-left groups (the Communists) also were elected to the EU Parliament on several occasions. The Green groups and the regionalist parties started gaining influence later with the EU enlargements (Corbett, Richard, et al 2011, 81).

The first direct elections to the EU Parliament occurred in 1979, and the number of members of the Parliament more than doubled at that time reaching 410. Greek accession in 1981 and Spanish and Portuguese accessions in 1986 changed political groups dynamic in the EU Parliament as new political party groups emerged while others split. After the third direct elections to the EU Parliament in 1989, a separate the Green Group formed for the very first time. The Communist Group split into two smaller groups: one was dominated by the Italian Reformists, and the other by the French Communists. However, these groups soon were absorbed by the other political groupings. Austrian, Finnish, and Swedish accessions to the EU Union increased the size of the Socialists, Liberal Green and GUE (Communist) groups with a substantial increase in the Christian Democrats (EPP). After the 1999 elections, the EPP group overtook the Socialist Group and become the largest group with 233 members in the EU 
Parliament. The membership among the Liberal Group, the GUE, and the Greens also increased since most of the regional parties joined the Greens (Corbett, Richard, et al 2011, 82-84).

The elections of 2004 occurred after the largest EU enlargement changed the dynamics in the EU Parliament. The membership in the groups of Socialists and the Christian Democrats slightly decreased, while the membership in the Liberal group increased. The Liberal group also changed its title to the Alliance of Liberals and Democrats for Europe (ALDE) and become the third largest group in the EU Parliament. The Green/EFA Group remained the fourth, and GUE/NGL the fifth in size in the EU Parliament (Corbett, Richard, et al 2011, 85).

The accession of Romania and Bulgaria to the EU in 2007 impacted the balance in the EU Parliament, and the three largest groups (the Socialists, Christian Democrats, and the Liberals Group) gained some members. After the election of 2009, the membership in the Christian Democrats and Socialist groups decreased again, partly because the British Conservatives left the EPP and founded the ECR group in the EU Parliament. The Liberal ALDE group also lost some of the members, but the Greens/EFA Group increased its membership from 43 to 55 (Corbett, Richard, et al 2011, 86).

Martin Steven (2014), Nathalie Brack (2012), Roger Scully, Simon Hix, and David Farrell (2012) investigate Eurosceptic political groupings in the EU Parliament. Scully et al argue that EU enlargement caused a significant exogenous shock to the EU institutions, and that the enlargement of 2004 had moved the ideological direction of the European Parliament towards the right and towards Euroscepticism. Scully et al. identify Europe of Freedom and Democracy (EFD) as the key Eurosceptic EU party (Scully, Hix, Farrell 2012, 671, 676).

Brack also studies Euroscepticism between July 2004 and January 2012 in the EU Parliament and agrees that EFD is the central Eurosceptic party. Brack argues that MEPs from 
Eurosceptic groups are freer to act within their group because they do not have to comply with rules of conduct and voting instructions. However, MEPs from the Eurosceptic groups (such as EFD) do not have much power in the EU Parliament and most of their actions are restricted to speeches and parliamentary questions (Brack 2013, 88-90).

Martin Steven studies Eurosceptic parties that emerged in 2009 with focus on the European Conservatives and Reformists (ECR) party group. ECR was created after the UK, Poland, and the Czech Republic become uncomfortable with the concept of the "ever closer Union" (Steven 2016, 1). Veronina Zapletalova and Magda Kominkova (2020) studied climate and energy policy in the European Parliament, by looking at roll-call votes from 2018-2019 (139). They find that Euroscepticism significantly influenced MEPs' decisions and that Eurosceptic MEPs usually reject energy policy completely (McElroy and Benoit 2011, 6). McElroy and Benoit (2011) discussed different approaches to measuring European policy positions in the context of European Parliament. They asked EU experts to place members of the party groupings in the European Parliament on predefined policy dimensions. These experts were members of academic institutions and several EP researchers who published on the topic. McElroy and Benoit conducted an expert survey of EP Party Group and their Policy Positions from April to June of 2004 (McElroy and Benoit 2011, 6-8). According to them, GUE followed by the Greens were the far-left political groups in the EU Parliament. The PES, the European Liberal and Democrat Reform Party (ELDR), and the EPP were on the leftof-center, center, and right-of- center. UEN and EDD party groupings were in the solid right positions (McElroy and Benoit 2011, 10).

According to McElroy and Benoit, on the issue of the environment, party groups were not very divided and clustered in the center. The exception was the Greens who favored the 
environment at all costs including the economic growth. Left-of-center on environmental issues remained GUE followed by PES, ELDR, EPP, UEN and EDD (McElroy and Benoit 2011, 13, 14). Political grouping in the EU Parliament have changed over the years, and different researchers classify political groupings slightly differently. But the reviewed literature allows me to conclude, that there were five main political party groupings in the EU Parliament from 1992 to 2014 :

○ Left-leaning socialists (S\&D, PES or PSE),

○ Center-right Christian Democrats (European Peoples' Party EPP, EPP-DE),

- Liberal group (ALDE),

- Radicals-Eurosceptic and the Right (European Free Alliance EFD, European Radical Alliance ARE, Union for Europe of the Nations UEN, European Conservatives and Reformists ECR),

- Greens (Vers/ALE, European United Left/Nordic Green Left or GUE/NGL), a pro-environment group

○ Non-associated - Some MEPs remained independent and did not join any political group in the EU Parliament ${ }^{3}$.

These political groupings have different stances on environment/energy issues. The Leftleaning socialists (S\&D) list the environment as a priority and argue for sustainable growth and prosperity by introducing a zero-pollution strategy of air and water quality (Our European Green Deal). The left-leaning Socialists argue for creating well-being for many while respecting “our planet's limits" (A new economic model for a progressive Europe).

The Christian Democrats also list sustainable development as one of their priorities and acknowledge that climate change is a reality. The Christian Democrats argue that a sustainable

\footnotetext{
${ }^{3}$ Some political groups (Group for Technical Coordination, GTC, the Communist Group) have dissolved before 1994, and are no relevant for my research.
} 
economy is beneficial to business, but that extreme economic changes are not needed to addressing challenges of climate change (A Sustainable Europe). The Christian Democrats also emphasize European Security and the Defense Union as their main priorities. They argue that Europe needs to address its security threats by securing external borders, preventing illegal immigration and fighting terrorism (A Secure and Free Europe).

The liberal ALDE party grouping does not pay too much attention to the environment and energy issues in their party platform, yet they stress that climate issues should be based on individual freedoms such as freedom of choice and rule, individual freedom, and climate justice (Rules of procedure for the LI Climate Justice Committee).

Radicals-Eurosceptics and the rightwing party grouping have changed their titles many times (from EFD to ARE, UEN, and ECR). The existing ECR party group stresses that climate change directives imposed by the European Union should not place unnecessary burdens on EU members. ECR members argue that the EU should stay away from unrealistic climate targets "which would never be implemented" (Protecting the Global Environment at a Cost we Can Afford).

In contrast, the Green party grouping emphasizes the collapse of biodiversity, exhaustion of natural resources, and other calamities that threaten the environment. The Green party groupings advocate for standing up to "status quo of mainstream policies to save the planet" and ensure equality for everyone (Our Vision).

In the following section I review written questions that members of the EU Parliament from all these political groupings submit to the EU Commission. Written questions to the EU Commission can explain behavior of the political party groupings, help to understand political party groups' priorities, and reveal whether these questions are submitted in accordance with 
their party lines. Most importantly, I am interested in how, if at all, MEPs respond to the focusing/punctuating events when utilizing this legislative tool.

\section{Reviewing Written Questions to the EU Parliament}

In my study, I examined written questions submitted to the EU Commission by the members of the European Parliament from 1994 to 2014. Parliamentary questions are direct form of parliamentary scrutiny of the European Council and the EU Commission. Each member of a political group or committee may submit a maximum of twenty questions over three months (Rule 130, Rules of Procedures 2019). Written questions to the EU Commission can help to explain the behavior of EU political party groupings and behaviors of individual MEP. Written questions also can show how the political party groupings react to punctuating events such as the Fukushima nuclear accident. MEPs have a right to ask questions to the EU Commission since the Treaty of Rome (1957), an in return the Commission must answer to these questions orally or in writing. Written questions also help MEPs to show constituents or other groups that they are active in the EU Parliament (Richard et al 2011, 63).

Written questions to the Commission are an important instrument that MEPs employ to obtain information from the Commission or to force the Commission to make a policy statement (Proksch, Slapin 60, 2010). Some researchers have studied questions that members of the national parliaments ask in their plenary meetings. Julie Sevenans and Rens Vliegenthart (2016) study oral parliamentary questions and interpellations asked in the plenary meeting from 1999 until 2008 in Belgium and from the period 1995 to 2011 in the Netherlands. Sevenans and Vliegenthart argue that media attention for an issue leads to an increase number of questions in the parliament about that issue (Sevenans, Vliegenthart 2016, 189, 192). 
Since MEPs were first elected to the EU Parliament in 1973, researchers have not paid significant attention to the EU Parliament and the written questions that MEPs ask. Emil Kirchner (1984) was one of the first researcher who investigated functions and composition of the MEPs from 1979 to 1984. Kirchner studies how MEPs' backgrounds affect their performance in the EU Parliament (Kirchner 1984, 3). He found a close relationship between MEPs' age and the number of questions they asked. Kirchner argues that younger MEPs tend to ask more questions in comparison to their older colleagues and suggests that perhaps older members have less need for personal publicity or have other methods of dealing with concerns of their constituents (Kirchner 1984, 79). Kirchner argues that MEPs ask most of their questions in their first year, but the number of questions fall considerably in their second year with slight recovery during their third (Kirchner 1984, 78).

Simon Hix, Tapio Raunio, and Roger Scully (2003) review published scholarly articles that focused on the European Parliament from 1965 to 2001. They note the brief of explosion of research around the 1979 when MEPs to the Parliament started to be elected directly, but after that research of the parliament has declined. The rebirth of interest in the EU Parliament occurred in the early 1990s with the Single European Act and the Maastricht Treaty (Hix, Raunio, Scully 192, 193, 2003).

Hix, Raunio, and Scully classify research on the EU into the four categories: studies on the general development and functioning of the EP; research on political behavior and EP elections; research on the internal politics and organization of the EP; and lastly examinations of inter-institutional relationship between the EP, the Council and the Commission (Hix, Raunio, Scully 193, 2003). According to Hix, Raumio, and Scully, most of the studies on political behavior concluded that national parties tend to convince voters that elections to the European 
Parliament are "super opinion polls" for the national parties. In other words, elections to the European Parliament are not as significant as elections to the national parliaments (Hix, Raunio, Scully 194, 2003). Only small amount of research from Hix, Raunio, and Scully's list were dedicated to study written questions to the European Parliament.

Tapio Raunio (1996) analyzes the content of written questions to study MEPs behavior. Raunio argues that the study of parliamentary questions is a useful tool to obtain knowledge our knowledge how MEPs understand their role as representatives (Raunio 1996, 356). He concludes that the number of written questions has been increasing from 1980 to 1995 (Raunio 1996, 29). Raunio argues that none of the political groups in the EU Parliament exclusively focus on a specific set of topics when asking questions to the EU Commission except for the Greens which display interest in environmental issues, public health, and consumer protection. EPP and the Liberal groups asked more questions related to economic, monetary, and industrial policies (Raunio 1996, 17). In general, from 1976 to 1983 questions on agriculture, economic and monetary matters were the most common questions, while questions on the environment were lagging. However, in 1992 the situation changed and social affairs, as well as environmental issues, made up the majority of the questions, leaving economic and monetary union behind (Raunio 1996, 18).

More attention has been given to EU questions to the EU Parliament in the recent years. Nathalie Brack and Olivier Costa (2019) argue that questions to the EU Commission allow it to recognize MEPs priorities and the perceptions MEPs have of their parliamentary mandate. According to Brack and Costa, MEPs ask questions for different reasons such as gaining information, controlling the executive, and developing reputation regarding a specific topic. Parliamentary questions also perform a micro-function for legislators such as generating 
publicity, defending territorial interest, and showing their constituency back in their home countries that their interest is being represented at the EU level (Brack, Costa 4, 2019).

Sven-Oliver Proksch and Jonathan B. Slapin (2011), and Christian Jensen, Sven-Oliver Proksch, and Jonathan Slapin (2013) also study written questions to the EU Parliament. Proksch and Slapin (2011) investigate how opposition parties uses written questions to the EU Commission to pursue the executive oversight. Proksh and Slapin argue that MEPs from national opposition parties are more likely to ask questions to the EU Commission (Proksch, Slapin 56, 2011). Proksch and Slapin constructed a dataset with information of the number of written questions each MEPs asked the Commission from 2004 till 2008. They discovered that British MEPs had one of the highest question counts with regards to the specific Commissioner. MEPs from the new member states stayed in the bottom of the list and did not ask many questions to the Commission. The areas that received most of the attention from the MEPs were environment, justice, freedom, security, and external relations (Proksch, Slapin 65, 2011). Proksch and Slapin found that MEPs from national opposition parties tend to ask more questions to the EU Commission than the MEPs from the governing parties (Proksch, Slapin 73, 2011).

In a related study Christen Jensen, Sven-Oliver Proksch, and Jonathan Slapin (2013) argue that MEPs ask written questions to the EU Commission to alert the Commission to potential improper implementation of EU law in the member states. In other words, parties in opposition at the national level use written questions to the Commission to ring a "fire alarm" to the Commission regarding failures by their political opponents in their national governments (Proksch, Slapin 260, 263, 2013).

As the above reviewed literature suggests, written questions to the EU Parliament can provide important information about the MEPs behavior. I intend to supplement this literature 
with my case studies. I am interested to see how MEPs respond to punctuating and focusing events such as the Fukushima nuclear disaster. I also investigate whether MEPs remain consistent to party ideology when submitting questions to the EU Commission.

\section{Methods}

Adapting Baumgartner and Jones' punctuating equilibrium theory (PET), I look for punctuations in nuclear energy, coal, wind, and hydraulic fracturing policy equilibriums. The main question, I seek to answer is whether punctuation equilibrium theory can be applied to studying the European Parliament. I want to see if there are any punctuations in energy policy in the EU Parliament, and what events cause these punctuations to occur. Analysis of written questions that MEPs submit to the EU Commission might help me to identify these punctuations. For example, I expect to see some negative questions towards nuclear energy after the 2011 nuclear disaster in Fukushima, where a major earthquake caused a 15-meter tsunami in Japan, disabling the power supply and cooling three Fukushima Daiichi reactors. As a result of the accident, the surrounding area was exposed to radioactive contamination (Fukushima Daiichi Accident, 2020). In contrast, I expected to see more positive questions and comments towards solar and wind energy as a countermeasure to nuclear energy.

First, I searched for key words in the European Parliament written question database that relate to a specific energy source from 1994 to 2014: nuclear energy, coal, wind energy, solar energy, and hydraulic fracturing. Each instance of these key words is recorded in a spreadsheet, wherein I examine the context in which these words have been mentioned. Then, I analyze the content of each question to determine whether the question is negative, positive, or neutral towards the respective power source. 
I have recorded and examined 601 written questions that MEPs submitted to the EU Commission which was a challenging task as many MEPs asked very technical questions regarding different energy sources; for this reason, it was very difficult task to identify whether the tone of a particular question was negative or positive. Some of the written questions were written in a sarcastic tone which made the classification process even harder.

Some written questions were straight forward and relatively easy to identify as positive or negative. For example, Independent MEP Hans-Peter Martin asked the Commission a negative question about wind energy. First Martin stated that the creation of jobs in wind energy causes people to lose jobs in Spain and that Spain's “leading race for wind energy, has sacrificed 2.2 jobs for every green job created." Then he asked the Commission how EU member countries can manage such losses? (Martin November 17, 2011). Another example of a negative question came from Willy Meyer of the Green party grouping; he asked the Commission if it did "not agree that nuclear power stations, which often make it impossible for clean production? a word missing... should gradually be closed down?" (Meyer December 7, 2010).

Questions like these I classified as negative as they clearly present a negative view towards an energy source. These questions were not too technical and did not seem to have sarcastic language or hidden meanings. Some positive questions were also easy to identified as MEPs who asked these questions favoring one energy source over another. For example, Rachida Dati (PPE), stated that the Mediterranean Solar Plan (an initiative to promote renewable energy) is a springboard for developing renewable energy and improving energy efficiency across the entire region. Then Dati asked the Commission if it is taking steps to ensure that all stakeholders will support the Mediterranean Solar Plan (Dati December 4, 2012). 
However, some of the questions were harder to identify as positive or negative due to a very technical language that was used; these types of questions are usually much longer. In cases of complicated and difficult questions, I sought help from technical experts. For example, a question concerning coal energy submitted by Karl-Heinz Florenz (PPE-DE) focused on non$\mathrm{CO} 2$ gases emitted by the active coal mines. Florenz argues that according to the new EU directives, it would become almost impossible to "use methane-containing mines gases in compact combined heat and power units, a use which is promoted under the law on renewable energy sources (Florenz September 29, 2006).” In several paragraphs of technical statements and comments, Florenz asked the Commission a number of questions regarding the regulation of methane gases. After discussing with the experts from energy and environment field, I classified this question as positive towards coal energy because in his statements, Florenz suggested that EU regulations towards coal energy are too strict and almost impossible to follow.

Another example of a technical question that I needed help with was about hydraulic fracturing technology. Kathleen Van Brempt (S\&D) who submitted this question discusses chemicals that are used in the "fracking" process. After discussing the hydraulic fracturing technology in general terms, Van Brempt asked the Comission "Has chemical disclosure always been made in the proper way for previous and current drilling activities. Is the Commission aware whether chemicals not authorized under REACH were used during current or previous drilling activities in the EU? If so, what action was taken against this?" (Van Brempt, October 2, 2013). As per suggestion from the experts, I classified this question as negative towards hydraulic fracturing because most of the chemicals used in the hydraulic fracturing process are 
deemed to be dangerous to human health. Therefore, Van Brempt was obviously concerned about the use of these chemicals.

Before beginning the analysis, it is also important to note that a significant portion of questions submitted to the EU Commission are neutral, rather than slanted for or against an energy source. For example, fifty-six of the 192 questions regarding nuclear energy were classified as neutral, because of the difficulty of identifying or implying the tone of the question. Most questions asked by the Verts/Ale party members towards nuclear energy were negative, but some were short and direct, thus it would not be correct to identify them as positive or negative. For example, Nuala Ahern of Verts/ALE, asked "What involvement have the Commission, Euratom or the EC Joint Research Centers had in the stakeholder dialogue on radioactive waste coordinated by the OECD's Nuclear Energy Agency and what resources have been committed by the Commission to this dialogue?" (Ahern June 13, 2002). This, and other similar questions, were classified as neutral, rather than "positive" or "negative".

\section{Cases Studies}

\section{A. Nuclear Energy}

The first energy source I examine is nuclear energy. The analysis is on Parliamentary questions asked from 1994 to 2014. I divide this research into two groups: prior to and following the nuclear disaster in Fukushima. I suspect that center-right and right-wing political groups in the EU Parliament would have been supportive of nuclear energy prior to the Fukushima tragedy, and would remain so after Fukushima. In contrast, I predict that left-leaning and green political parties and groups such as S\&D and Verts/ALE would be critical of nuclear power plants before Fukushima and become even more so after. My findings are presented in Figure 1: "Nuclear Energy Dynamics in Written Questions to the EU Parliament." 
Figure 1. Nuclear Energy Dynamics in Written Questions to the EU Parliament

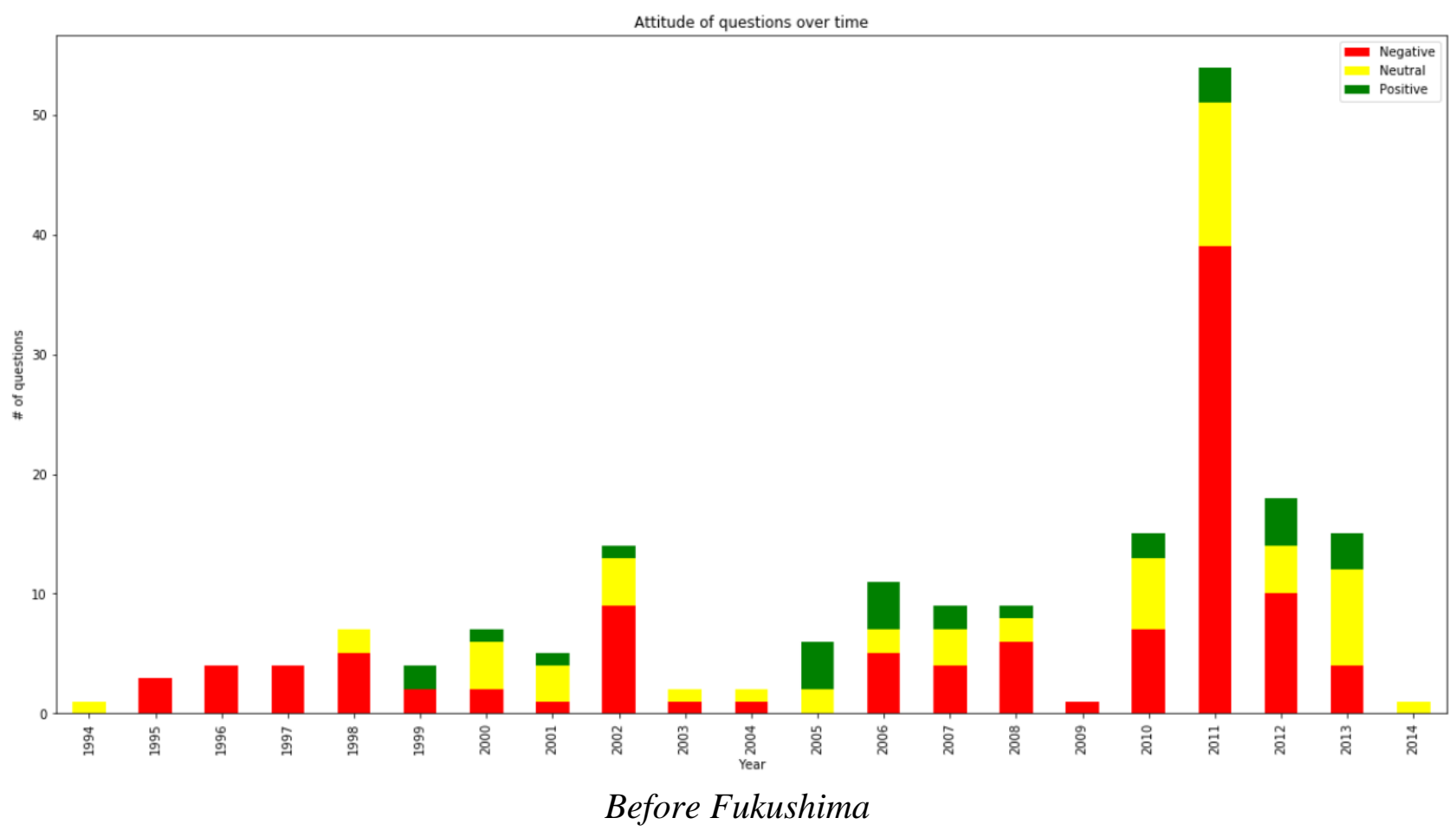

Before the disaster in Fukushima, nuclear energy was perceived as a better alternative to coal-based energy. Although many MEPs opposed nuclear energy for fear of radioactive incidents, their opposition was not fierce. In 2000, the EU Commission received seven questions regarding nuclear energy. Six of these questions were asked by members of the green group (Verts/ALE group, Germany). Four of these six questions were neutral and two were negative.

The number of nuclear energy questions submitted to the EU Commission increased slightly in 2002, and significantly dropped in the following years. Most of the question came from the Green (Verts/ALE) political grouping. The Greens (Verts/ALE) did not ask any positive questions related to the nuclear energy. From 2005 to 2010, the dominant questions to the EU Commission regarding nuclear energy were mainly negative or neutral, and only a few MEPs from the Christian Democratic party grouping expressed a positive opinion towards this energy source as an alternative to the coal energy. 
In 2011, German Herbert Reul from the Christian Democrat PPE party expressed concern that without nuclear power it would be economically impossible to achieve global climate objectives. Reul argued that without nuclear energy, countries would have to depend on coal, gas, and renewable energy sources. Reul criticized the new International Atomic Energy Agency (IEA) scenario in which the EU's share of nuclear energy worldwide would be $10 \%$ in 2035 rather than $14 \%$. Reul also asked the EU Commission whether it was aware of the "rising energy prices in Germany's neighboring countries after the announcement that eight nuclear power stations were to be shut" (Reul July 22, 2011).

Christian Democrat Carlos Robles Piquer from (PPE) Spain expressed concerns about decreasing support for the nuclear energy. Piquer criticized "some countries" attempts to dismantle their nuclear installations, calling these efforts "emotional." According to Piquer, worldwide energy demand will not be met without nuclear power in the energy mix (Piquer January 27, 1999).

MEPs who submitted positive questions to the EU Commission did not praise nuclear power as a safe and sustainable energy source, but rather as a better alternative to coal and gas power. W. G. van Velzen from the Christian Democrats group (PPE-DE, Netherlands) expressed support for the Czech nuclear power station in Temelín. Van Velzen suggested that given the "current oil crisis," the Commission should put more effort into creating EU safety standards for nuclear power. He also asked whether "there was an EU policy on the safe processing and storage of nuclear waste." Van Velzen suggested that new EU safety standards for nuclear power plants would increase public support of nuclear energy (Velzen November 8, 2000). 
Ultimately, before the Fukushima accident, MEPs stayed within their party lines, therefore, The Greens were negative towards the nuclear energy when the Christian Democrats perceived nuclear energy as a better alternative to coal.

\section{After Fukushima}

The most significant increase in questions regarding nuclear energy occurred in 2011 after the Fukushima nuclear power plant disaster. Before the Fukushima nuclear disaster, the Green party groupings such as (Verts/Ale) were negative towards nuclear energy, but after the Fukushima, all the political party groupings, with a few exceptions, expressed concerns towards nuclear power. Hence, the negative questions came from all the party groupings: twelve questions came from Christian Democrats (PPE), nine from Eurosceptic populists (EFD), eight from the Socialists (S\&D), thirteen from Greens (Verts/Ale and GUE/NGL), and several from the independent members of the EU Parliament. Only two members from the Christian Democrat group (PPE) expressed positive views towards nuclear energy in 2011. They were Herbert Reulv from Germany, and Elżbieta Katarzyna Łukacijewska, PPE from Poland.

Other Christian Democrats (PPE) joined the majority of MEPs from all party groupings and submitted critical questions to the EU Commission. For example, Georgios Koumoutsakos from Greece asked the Commission what the Commission was going to do with the prospective EU member countries like Turkey, which was planning to build a new nuclear power plant in a region at high risk of earthquakes (Koumoutsakos, June 21, 2011). Rodi Kratsa-Tsagaropoulou, (PPE) from Greece, also asked the Commission about Turkey's planned nuclear power plant, and how the Commission was going to ensure its safety (Tsagaropoulou, April 20, 2011). Giovanni Collino from Italy, representing the Christian Democrats group (PPE) was concerned 
about the Fukushima disaster in Japan and asked the Commission how it was going to address nuclear power plant safety in France (Collino April 15, 2011).

While France rely relied heavily on nuclear energy, MEPs from France also submitted written questions to the Commission criticizing the nuclear power plants. One of them was Jean-Pierre Audy, representing Cristian Democrats (PPE) who asked the Commission which public body in the European Union is responsible for energy safety and how safe the nuclear industry is in the EU (Audy March 24, 2011).

The exception to this opposition was a Christian Democrat from Poland who was supportive of the nuclear energy. Elżbieta Katarzyna Lukacijewska (PPE) asked the Commission as to whether it would support nuclear power plants in Poland. Eukacijewska referred to the Euratom framework program for 2012-2013 and the implementation of the "Innovation Union," which was intended to speed up the implementation of nuclear energy innovations (Łukacijewska July 15, 2011). Łukacijewska expressed concern about energy security and climate change, claiming that nuclear energy would help to address these issues.

Another exception was Vladko Todorov Panayotov from the Liberal party grouping (ALDE) Bulgaria who asked three questions regarding nuclear energy. Two of these questions I identified as neutral, and one as positive. Panayotov pointed out that the Fukushima disaster opened a debate between environmental associations and politicians about the future of nuclear energy. Panayotov argued that regardless of the accident in Fukushima, nuclear energy was essential, yet he wish for it to become more reliable (Panayotov April 11, 2011). His other questions raised some safety concerns, but overall, they were not negative towards nuclear energy. 
The Fukushima disaster triggered a spike in negative questions among all of the political party groupings, but this spike was short-lived. In subsequent years the number of questions mentioning nuclear energy substantially decreased. The nature of the questions asked after 2011 are very similar to the context of the questions asked prior to the Fukushima disaster. A large number of these questions did not specifically address nuclear energy, but mentioned nuclear energy in the context of other energy sources.

However, the Green political party groupings remained critical of nuclear energy as they were prior to the Fukushima disaster. Jean-Luc Mélenchon, from France representing the Green party grouping (GUE/NGL) was very negative towards nuclear energy and declared that phasing out nuclear energy was essential. Mélenchon demanded political leaders take their "heads out of sand" and address the safety of nuclear power plants. He asked the Commission whether "the Council [is] going to safeguard European public interest and work on drawing up a nuclear exit strategy" (Mélenchon March 24, 2011).

Some other political party groupings also remained skeptical towards nuclear energy; for example, the Radicals Eurosceptics from different countries also expressed concerns towards nuclear power plant. Mara Bizzotto from Italy representing the radicals-Eurosceptic group asked two questions: one regarding the safety of nuclear energy in the wake of the Fukushima tragedy, and the other asking whether the Commission was aware of Russia's plans to build a nuclear power plant at the Baltiysky shipyard in St. Petersburg (Bizzotto May 5, 2011, Bizzotto, May 19, 2011).

Some MEPs from the Liberal and Greens party groups asked questions to the EU Commission collectively. Luigi de Magistris, ALDE from Italy, Ivo Vajgl, ALDE from Slovenia, and Michèle Rivasi, Verts/ALE from France, asked if the Commission intended to ban nuclear 
power from the energy mix under the EU 2020 strategy. They called on the Commission to urge member states to set up an independent authority to check whether nuclear power plant operators are complying with rules and performing inspections, and to shut down plants when needed (Magistris, Vajgl April 4, 2011).

MEPs from the Socialists party groupings (S\&D) were also negative towards nuclear power plant. Jörg Leichtfried and Hannes Swoboda from Austria asked if the Commission would provide “open and honest conclusions on the role of nuclear power in Europe's energy mix following the events in Japan” (Leichtfried, Swoboda March 24, 2011). Monika Flašíková Beňová representing the Socialist party from Slovakia asked the Commission if it was going to address concerns regarding the construction of a new nuclear power plant in Turkey, where up to $90 \%$ of the country is prone to earthquakes (Beňová, October 19, 2011).

\section{Summary}

At first glance, it appears that the Fukushima nuclear accident was a punctuating event that prompted MEPs to pay more attention to the nuclear energy. However, this punctuation did not last long: in 2012 questions regarding nuclear energy decreased substantially, and only a few questions were asked in 2013 and in 2014.

The data presented in the Figure 1, suggest that the Fukushima accident did not fundamentally changed MEPs' behavior. According to PET (Baumgartner and Jones), policy changes occur when positive tone regarding particular policy changes to negative tone. In the U.S nuclear energy policy case, negative topics came to dominate congressional attention to nuclear power after the Three Mile Island nuclear plant accident in 1979 (Baumgartner, Jones $2009,74)$. The accident helped to change image of nuclear power from positive to negative for years to come. But in the European Parliament, this type of lasting change in nuclear energy 
policy is not noticeable in the written questions that MEPs submitted after the 2011 nuclear accident. In other words, the Fukushima accident created an opportunity for the policy change. Fukushima also changed the framing of the nuclear energy policy. Before this accident, nuclear energy was mostly perceived as an alternative to coal, but after this energy source was viewed primarily as a safety issue.

The Fukushima accident also provided some information about the political party groupings' behavior. Prior to the nuclear disaster in Fukushima, MEPs questions to the EU Commission regarding nuclear energy were neither overwhelmingly positive nor negative. MEPs from the Green political party groupings criticized nuclear energy, while other MEPs perceived nuclear energy as better alternative to coal. But the nuclear accident of 2011 reminded the world of the risks of nuclear power.

After the Fukushima tragedy, the socialist, liberals, radical-Eurosceptics, and the Greens criticized nuclear energy and expressed safety concerns. Just after the incident, negative questions regarding nuclear energy dramatically increased and almost all questions were negative except for some Christian Democrats (PPE). Prior the Fukushima incident, Christian Democrats expressed support of nuclear energy, and even after the tragedy they did not criticize nuclear energy as fiercely as MEPs from the Green party groupings.

\section{B. Hydraulic Fracturing}

In this section I explore how the attitude towards hydraulic fracturing has changed in Europe over time and present my findings in the Figure 2. "Hydraulic Fracturing Dynamics in Written Questions to the EU Parliament." Hydraulic fracturing is a widely used method to extract oil and/or gas from tight shale formations, to stimulate oil and gas production, and to release natural gas stored within layers of rock (Adams 2011, 1340). Several EU members have 
substantial shale-gas basins which by its size almost match the North America basins where hydraulic fracturing become prevalent in the last ten years (Frack to the Future 2013, 53).

However, hydraulic fracturing requires mixing millions of gallons of water with chemicals such as biocides and certain petroleum products to stimulate the process. These chemicals, injected into the ground at a high pressure, are associated with health risks ranging from rashes to cancer, and cause additional harmful effects that include disruption of the endocrine system, adverse fetal development, and detrimental human behavior (Clarke, Pappas 2012, 61).

Figure 2. Hydraulic Fracturing Dynamics in Written Questions to the EU Parliament

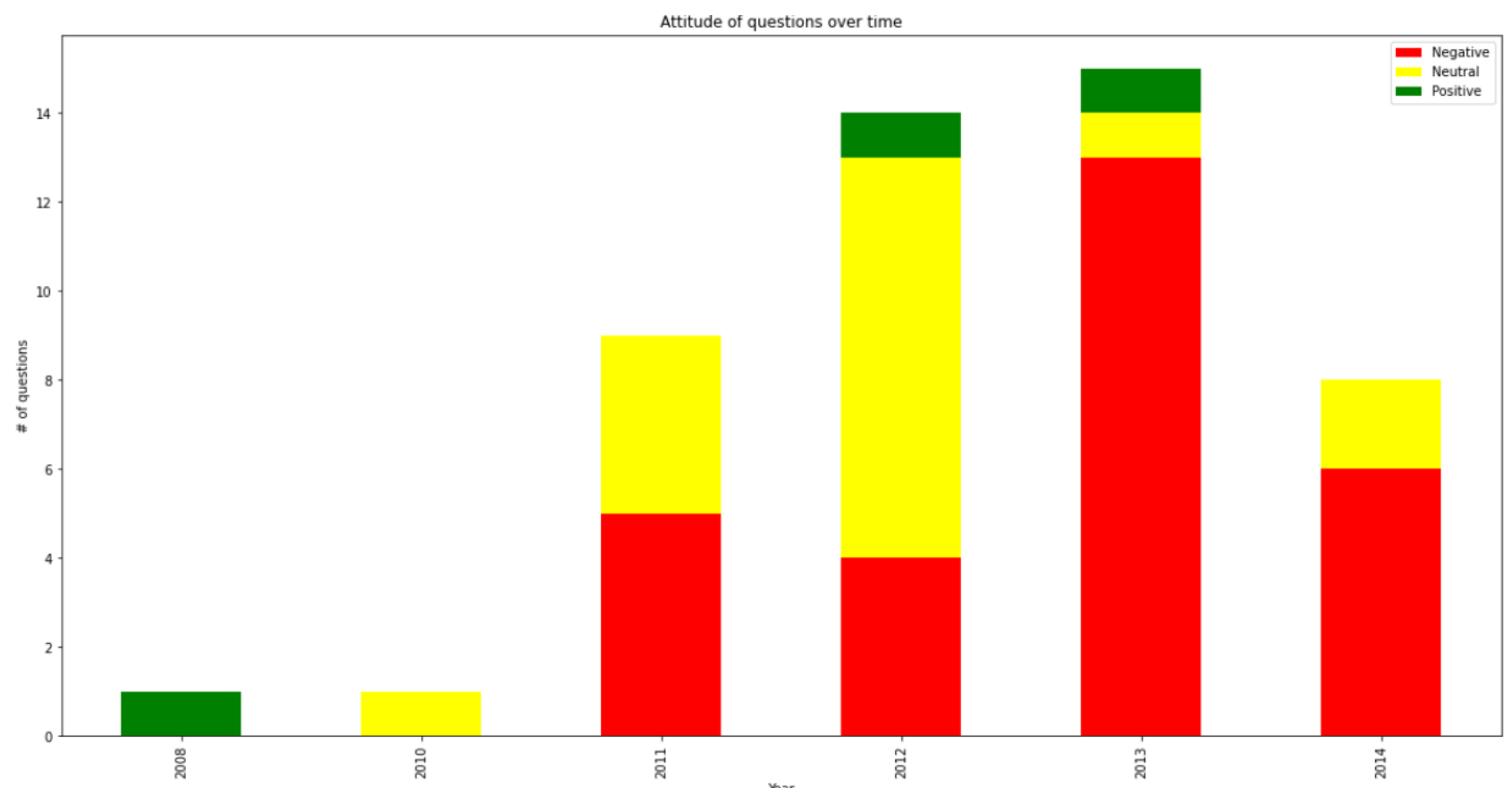

In terms of EU Parliamentary questions, hydraulic fracturing received largely negative attention, with a few exceptions from Christian Democrats and the Eurosceptic Party Groupings. The first question about hydraulic fracturing was asked in 2008 by Emmanouil Angelakas from Germany representing Christian Democrats, (PPE-DE). Angelakas encouraged 
the EU Commission to investigate hydraulic fracturing in order to ensure energy security from Russia for several EU countries. According to Angelakas, Austria, Hungary, Sweden, and Poland would benefit from hydraulic fracturing. Angelakas asked the Commission whether the Commission would cooperate with the United States to gain experience on hydraulic fracturing (September 30, 2008). The Christian Democrats have always emphasized national and energy security, and this notion was reiterated in their 2019 Manifesto. Christian Democrats aims to create a true EU Energy Union where electricity can be shared freely among EU members. They also stress the importance of reducing $\mathrm{CO} 2$ emissions and enabling investments and innovation in all technological solutions to low-carbon mobility (PPE Manifesto 2019).

Zbigniew Ziobro from Poland representing the radical-Eurosceptic party (EFD) asked the EU Commission whether it was aware of a report published by the Polish Geological Institute (PGI) assessing the environmental impact of the hydraulic fracturing process that was carried out at the Łebień LE-2H well in Poland. The report gave a "green light" to hydraulic fracturing in Poland and stated that hydraulic fracturing should not damage air, soil, and water if drilling is conducted in accordance with legal regulations. According to the PGI, the large quantities of water needed for hydraulic fracturing operations would not deplete ground water resources (Polish Geological Institute, 2011).

Ziobro asked whether the Commission had considered PGI's report for hydraulic fracturing analysis. Ziobro pointed out that Poland had significant experience in shale gas exploration and encouraged the Commission to consult with Poland when preparing their report on hydraulic fracturing (Ziobro March 8, 2013).

Bogusław Sonik, from the Christian Democrats (PPE) party grouping also from Poland asked the Commission about the same PGI report. Like his colleague from EFD, Sonik 
emphasized Poland's experience with hydraulic fracturing, pointing out that Poland had successfully performed hydraulic fracturing in nine wells. Sonik asked the Commission if it was going to send representatives to carry out field research and visits to wells in Poland (Sonik December 13, 2012).

These Polish MEPs were the most vocal proponents of hydraulic fracturing. Poland's enthusiasm is likely due to their dependence on Russian energy. The discovery of shale gas resources brought hopes of ensuring energy security and promoting economic growth. Sylwia Slupik (2013) argues that shale gas extraction is important for Poland's social and economic growth. She emphasizes that shale gas extraction could play a central role in shaping the Polish energy market, attracting a substantial number of projects related to energy security (Slupik 2013, 329).

The remaining of questions regarding hydraulic fracturing are neutral and negative. The Greens MEPs of the EP submitted the most negative questions to the EU Commission. Ana Miranda from Spain representing the Green party grouping (Verts/ALE) submitted seven very critical questions about hydraulic fracturing. In 2013, Miranda informed the Commission that the Catalan and Spanish governments had allowed Teredo Oil Limited Segunda Sucursal SL to search for gas over a period of six years in the Ripoll area. Miranda noted that the area in question had been designated as an Area of Natural Interest and that several local Councils objected to the gas exploration and possible hydraulic fracturing. Miranda asked the Commission if farmers would qualify for compensation for their land which could be damaged by such "fracking." Miranda also requested that the Commission to take a stance against hydraulic fracturing which is "damaging to the environment and to human beings" (Miranda February 15, 2013). Miranda's other questions to the EU Commission are similar. She points out that studies 
on hydraulic fracturing have revealed the dangers fracking poses to the environment and human health. Miranda suggests that hydraulic fracturing is not compatible with European water legislation, conservation, and agricultural activities (Miranda May 22, 2013).

Willy Meyers from also from Spain representing the Green party grouping (GUE/NGL) referred to the earthquakes that occurred in Valencia and Catalonia regions in 2013 and argued that these earthquakes were causally linked to hydraulic fracturing. Meyers asked the Commission if it could call on "Spain to halt development on all similar projects due to the clear risk involved" (Meyers October 7, 2013).

Several positive and neutral questions in 2008 and 2011 suggest that some MEPs were initially enthusiastic about hydraulic fracturing and hoped that this new technique would help ensure energy security for EU members. However, new research and studies advised that hydraulic fracturing is a dangerous practice. Negative questions peaked in 2013 and were asked by members of various political parties from Spain, Ireland, Belgium, and France.

\section{Summary}

Based on the data, it does not look like hydraulic fracturing policy was affected by the Fukushima nuclear accident (Figure 2). But the perception of hydraulic fracturing started to change in 2011 without a noticeable punctuating event. According to PET, not all policy changes require a punctuating event. I suggest that the hydraulic fracturing policy case resembles the pesticides policy in the U.S (see Chapter One, Page 13). Pesticides enjoyed positive media coverage that promoted their use to help American farmers and end hunger by increasing agricultural productivity. However, pesticides policy started changing incrementally and this change was impacted by scientific studies and the resulting negative media coverage that emphasized the danger pesticides posed to health and to the environment. Like 
pesticides in the U.S., hydraulic fracturing initially was viewed favorably by MEPs as a new and promising technology to extract shale gas. This positive view started changing in 2011 as more studies and data regarding the negative impacts of hydraulic fracturing effects came to light. As a result, MEP questions concerning hydraulic fracturing became overwhelmingly critical, except for MEPs representing Christian Democrats (PPE) and radical-Eurosceptics (EFD) from Germany and Poland.

\section{Coal Energy}

In comparison to other energy sources, coal energy received the most critical questions from members of the EU Parliament in my study. As one of the oldest fossil fuels in use, coal energy faced harsh negative attention from MEPs between 1994 and 2014. My findings on coal energy dynamics are presented in the Figure 3. "Coal Energy Dynamics in Written Questions to the EU Parliament".

Figure 3. Coal Energy Dynamics in Written Questions to the EU Parliament

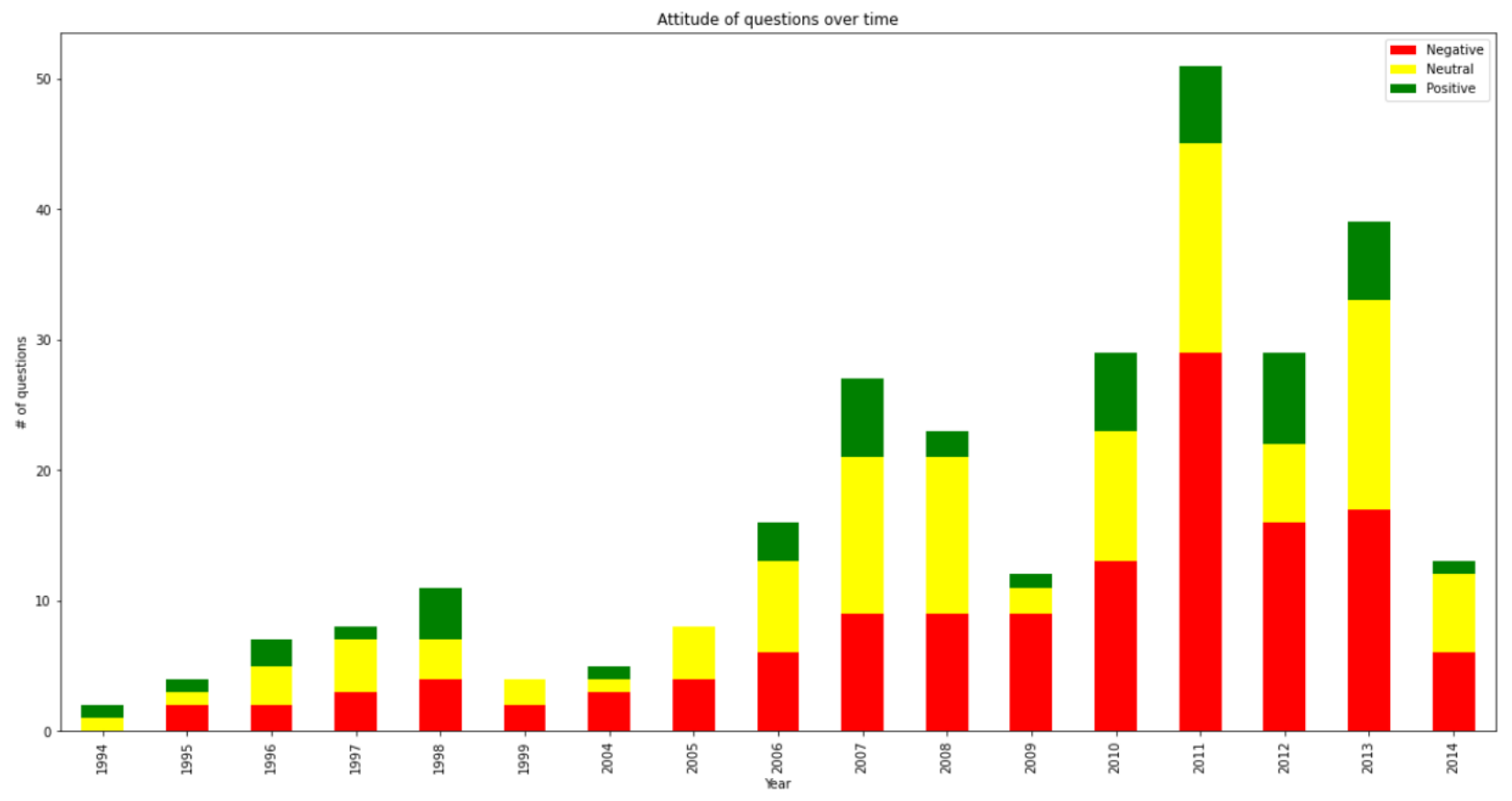


The Green party groupings (Verts/ALE and GUE/NGL) from most of all the EU countries were overwhelmingly against the coal energy. MEPs from the EU countries that joined the EU before 2004 were the most active in submitting questions to the EU Commission. For example, MEPs from Germany submitted thirty questions to the European Commission and most of these questions were negative.

Hiltrud Breyer from the Green (Verts/ALE) party grouping tracked pollution caused by the coal power plants and coal mining companies in Germany and in other European countries. In 2005, Breyer criticized Maritsa East energy complex in central Bulgaria as the major polluter in Europe because the plant burned a low-quality coal, used old technology, and lacked modern cleaning facilities. Breyer asked the Commission whether the Commission would guarantee Bulgaria's compliance with the EU environmental regulations once Bulgaria joins the EU (Breyer June 13, 2005).

Erik Meijer from the Netherlands representing the green party grouping (GUE/NGL) submitted several descriptive questions to the Commission. All the questions portray the coal industry in the negative light. Meijer was concerned that workers' rights were violated on the island of Mindanao in the Philippines in the Paper Industries Corporation of the Philippines (PICOP). PICOP was the biggest business in the region and used a highly polluted coal as a fuel discharging large quantities of mercury and polluting adjoining areas of the sea. Meijer suggested that Commission had responsibility to protect vulnerable workers and address problems of deforestation, pollution, and odor nuisance that PICOP was causing in the Philippines (Meijer February 17, 2006). 
Members of the Christian Democrats (PPE) and the Socialist party groupings (S\&D) as well as some independents MEPs were not supportive of the coal industry, but their criticism of coal was not as fierce as their competitors from the Green groups (Verts/Ale).

The Christian Democrat party grouping was more "forgiving" to the coal industry and focused on energy security and independence that coal energy might help to achieve. A member of the Christian Democrat party grouping, Agustín Díaz de Mera García Consuegra (PPE), pointed out that mining in northern Spain ensured energy independency for the country and provided a livelihood for thousands of people in the Leon, Palencia and Asturias regions. Consuegra criticized the Commission's decision to end aid for the coal mining sector and asked Commission "what measures would the Commission recommend preventing the mining areas affected from dying out?" (Consuegra August 19, 2010).

In most cases MEPs from S\&D, GUE/NGL, Verts/ALE, and ALDE party groupings sided with the environmentalists and did not support coal industry. Social democrats (S\&D) from several EU member countries criticized coal energy and criticized the other EU members that were in favor of coal energy.

Social democrat Gilles Pargneaux from France noted that the Polish government received free carbon credits for coal power plants that do not exist. According to Pargneaux, the Polish Government applied for free credits worth EUR 33 million for its coal power plant in Łęczna, "however, having arrived at the location, the EurActiv journalists found that the supposed site of the plant contained nothing but grass, fields and forest paths” (Pargneaux July 17, 2012).

Evangelia Tzampazi and Anni Podimata from the Socialist party grouping (PSE) asked the EU Commission if it was aware of plans to build a coal-fired power station in the Vegora area of the municipality of Filota. Tzampazi and Podimata pointed out that the area in question 
was already suffering environmental pollution of carbon dioxide, sulphur dioxide and microparticle emissions from existing plant. They also asked how the Commission was going to address this issue (Tzampazi; Podimata March 5, 2009).

Monika Flašíková Beňová from Slovakia, also representing the Socialist party grouping, argued against a new coal power plant construction in southwest Poland because this power plant did not a have carbon dioxide capture and storage facility as required by European legislation (Beňová October 15, 2013).

In contrast to his colleagues from S\&D, Adam Gierek noted that the EU anti-coal and zero-emission policy is harmful to Poland's economy. Gierek argued that anti-coal and zeroemission policy "has its basis not in opinions backed up by unequivocal scientific proof, but rather in the Commission's belief in the IPCC's hypothesis that anthropogenic emissions are changing the climate" (Gierek April 2012, 11).

Social Democrats from the UK did not support coal as fiercely as their Polish counterparts, but were focused on clean coal technology. Glenis Willmott from the Socialist (PSE) party grouping was in favor of clean coal. Willmott asked whether the Commission planned to aid the EU members that wished to install clean coal technology knowing that cost of such technology was extremely high (April 30, 2007).

Several years earlier, Richard Corbettne also from the (PSE) party, asked the Commission about the clean coal technology. Corbett suggested that upgrading old, coal-fired power stations to modern "clean coal" power station was the most effective way of cutting CO2 emissions in Europe (Corbettne January 6, 2005).

With a few exceptions, MEPs from the Green party groupings were very critical of the coal energy. Spanish members of the GUE/NGL together with members of PSE party 
expressed positive opinion about coal. Members of GUE/NGL and PSE parties were concerned that subsidies for mining were cut in the Asturias region and that losses of subsidies would result losses of jobs in the region. GUE/NGL and PSE representatives asked the Commission what action the regional Government should take to maximize production and employment in the Asturian mines (January 30, 1998).

GUE/NGL members from Spain were more concerned about workers' rights and their livelihoods than the environment, hence their questions were different from the questions asked by their colleagues from the Netherlands and Greece. Coal mining and coal energy has deep roots in Spain's history and used to enjoy subsidies from the government. In 1986 Spain joined the EU and had to make some adjustments and reduced subsidies to its coal sector. Since 1986, Spain has gone from having 234 mining companies and 45,212 employees to 27 companies and 8284 employees not counting indirect job losses in areas related to coal mining (Rabanal 2009, 4375, 4377).

Alyn Smith from Verts/ALE, Scotland was the only Verts/ALE member who expressed favorable opinion towards the clean coal technology. In 2007, Smith stated that Scotland was supporting a proposed carbon capture project at the Peterhead power station which was supposed to be one of the most important European energy projects (Smith February 8, 2007). Smith's positive view towards coal energy was inspired by a promising carbon capture technology. Hence in his question Smith asked whether Commission was going to support similar projects in the EU.

Besides Poland and the Czech Republic, UK has the largest hard coal reserve in Europe (Kavouridis, Kouhouzas 2008, 694); however, "the general trend in coal mining was on decline, and coal production in 2000 was a quarter of the level in 1980 and only a third of the level in 
1990" (The United Kingdom 2002 Review 75, 2002). As a result, many coal miners lost their jobs, hence it is likely that for this reason MEPs from the UK were not overly critical of coal energy, and in several cases fiercely argued for coal energy.

Independent Ashley Mote`s question to the EU Commission was primarily focused on aluminum plants that were closed in the UK, and as a result of this closure thousands of people lost their jobs. Mote held the EU laws and the EU Commission responsible for closure of Lynemouth plant in Northumberland and pointed out that this plant also generated its own electricity from its own coal power plant. Mote claimed that "EU bureaucrats have decreed that it failed to comply with the Large Combustion Plants Directive, and therefore must close" (Mote February 3, 2009). As an independent and not being associated with any political group or party in the EU Parliament, Mote expressed his dissatisfaction with the EU Commission and the EU. Mote even sarcastically asked the Commission whether it is "proud of its success in destroying so many British industries over the years" (Mote February 3, 2009).

Some members from radical-Eurosceptic party groupings strongly criticized coal energy, while others asked supportive questions. Oreste Rossi from Italy, representing the radicalEurosceptic party grouping (EFD) in the EU Parliament inquired the Commission whether the Commission was concerned about "fine particle concentrations" in the developing countries. Fine particulates mostly come from coal-fired power stations and motor vehicle and are harmful to the respiratory tract. Rossi asked the Commission what steps the Commission was going to take to reduce the presence of fine particle concentrations (Rossi October 17, 2011).

However, Mara Bizzotto, another MEP from the radical-Eurosceptic party grouping from Italy, was supportive of "clean coal" technology. Bizzotto supported carbon capture and storage systems in power station in Porto Tolle in Rovigo. She asked the Commission whether it 
confirmed that it was in favor of clean coal-fired power stations that use CCS technology? (Bizzotto July 12, 2011). In a similar way, Tomasz Kamiński from Poland representing the radicals-Eurosceptic party grouping (ECR) criticized taxing on carbon emissions, claiming that imposing the EU-wide tax would be a clear violation of Member States' national sovereignty. Kamiński added that if Ireland, Sweden, and Finland chose to enforce a national carbon tax it is their right to do so, but this law should not be forced on other member states (Kamiński June 30, 2010).

Konrad Szymański, (ECR), from Poland argued that applying a uniform standard for limiting CO2 emissions would mean increasing dependence on gas imports from Russia, compromising Poland's national security. Szymański emphasized that countries in Central Europe did not have the same sources of sustainable energy as countries in Western Europe, and in Poland's case, it was better to use local coal than Russian gas (Szymański July 20, 2010).

Lithuanian Juozas Imbrasas representing EFD party grouping noted that Lithuania depended on Russian energy and invited the Commission to consider a common energy policy. According to Imbrasas, "the common EU energy community could exploit its own resources, i.e., shale gas and coal" (Imbrasas April 23, 2014). Imbrasas emphasized national security and expected that common EU energy policy might decrease dependency from Russia.

\section{Summary}

Only several MEPs asked questions about coal energy in 1994, and these questions were positive and neutral, yet numbers of questions started increasing in 1995, and most of these questions were negative. Questions towards coal energy and in the same time numbers of negative questions towards coal energy started increasing and reached their peak in 2011 which coincided with the Fukushima tragedy. Unlike nuclear energy, coal did not experience one 
major punctuating incident that shifted MEP's opinion from positive or neutral to negative, as coal has not been perceived favorably in the European Parliament since 1995 and negative questions towards coal energy were increasing incrementally which is consistent with PET theory. During the years of my study, many MEPs were reporting different environmental and health problems caused by coal power plants, for example, fine particle concentration, environment pollution, etc.

The coal policy dynamics in the EU Parliament also resembles the pesticides policy change in the U.S mentioned above regarding hydraulic fracturing. It is also likely that the Fukushima nuclear accident prompted MEPs to submit more energy related questions in 2011, and as a result coal received more attention negative attention.

When it comes to the party dynamics in the EU Parliament, the Green political groupings were overly critical of coal energy including the "clean coal". The only exception was one MEP from Verts/ALE party, representing Scotland, who was enthusiastic about clean coal technology and welcomed proposed carbon capture project at the Peterhead power station. Other exception was MEPs from the Green party grouping (GUE/NGL), Spain. These MEPs were concerned about eliminated subsidies to coal energy producers and the lost livelihoods of the coal miners. These were the few incidents when MEPs from the Green party grouping departed from the party lines and expressed support for the coal energy. In these cases, national interest superseded MEPs' allegiance to their EP party groupings.

Almost all MEPs from Poland Socialist and radical-Eurosceptics (S\&D, EFD parties) party groupings expressed favorable opinion towards coal and complained about the EU anticoal and zero-emission policies which were damaging Poland's economy. In general, most of 
the MEPs from the social democrat party groupings were skeptical of coal, but Social Democrats from Poland expressed support to the coal industry.

Some MEPs representing radical-Eurosceptic supported coal energy when others fiercely objected. This finding corresponds with Brack's study (2012) where she claims that MEPs from Eurosceptic groups are freer to act within their party grouping. Therefore, radicalEurosceptic MEPs acted in the interest of their home countries. Eurosceptic MEPs from Poland and Lithuania emphasized energy security and supported coal energy, whereas Eurosceptics from other EU member countries emphasized environmental and health concerns, generally objecting to the coal industry.

\section{Wind Energy}

As the data presented in the Figure 4. "Wind Energy Dynamics in Written Questions to the EU Parliament" suggests fewer MEPs submitted questions regarding wind energy, but most of these questions were positive. Most MEPs from all of the party groupings perceived wind energy and windmills as new instruments that would help to reduce carbon emissions and ensure energy security. However, some MEPs did not fully support the development of wind farms because they destroy the landscape and kill the birds. The first Parliamentary questions about wind energy were asked in 1998 and 1999 by Italian and German MEPs from the Christian Democrat (PPE) party grouping. Both questions were positive towards wind energy as a new renewable energy source.

In later years, the EU Commission received more negative questions about wind energy, but the positive questions and comments dominated the wind energy debate. The number of negative and positive questions towards wind energy increased in 2011 and 2012 after the Fukushima disaster. Spikes in the number of questions suggests that the Fukushima tragedy was 
a punctuating event that inspired policymakers to seek alternative, renewable energy sources to replace nuclear energy.

Independent Angelika Werthmann from Austria reminded the Commission about the nuclear energy disaster in Japan and inquired what programs the Commission was employing to encourage member-states to use renewable energy (Werthmann March 15, 2012). Kathleen Van Brempt, the socialist party group (S\&D) Belgium expressed her support for wind energy on several occasions. Van Brempt was content with large-scale windmills at sea and on land but was not sure if they generated enough electricity (Van Brempt July 7, 2011).

\section{Figure 4. Wind Energy Dynamics in Written Questions to the EU Parliament}

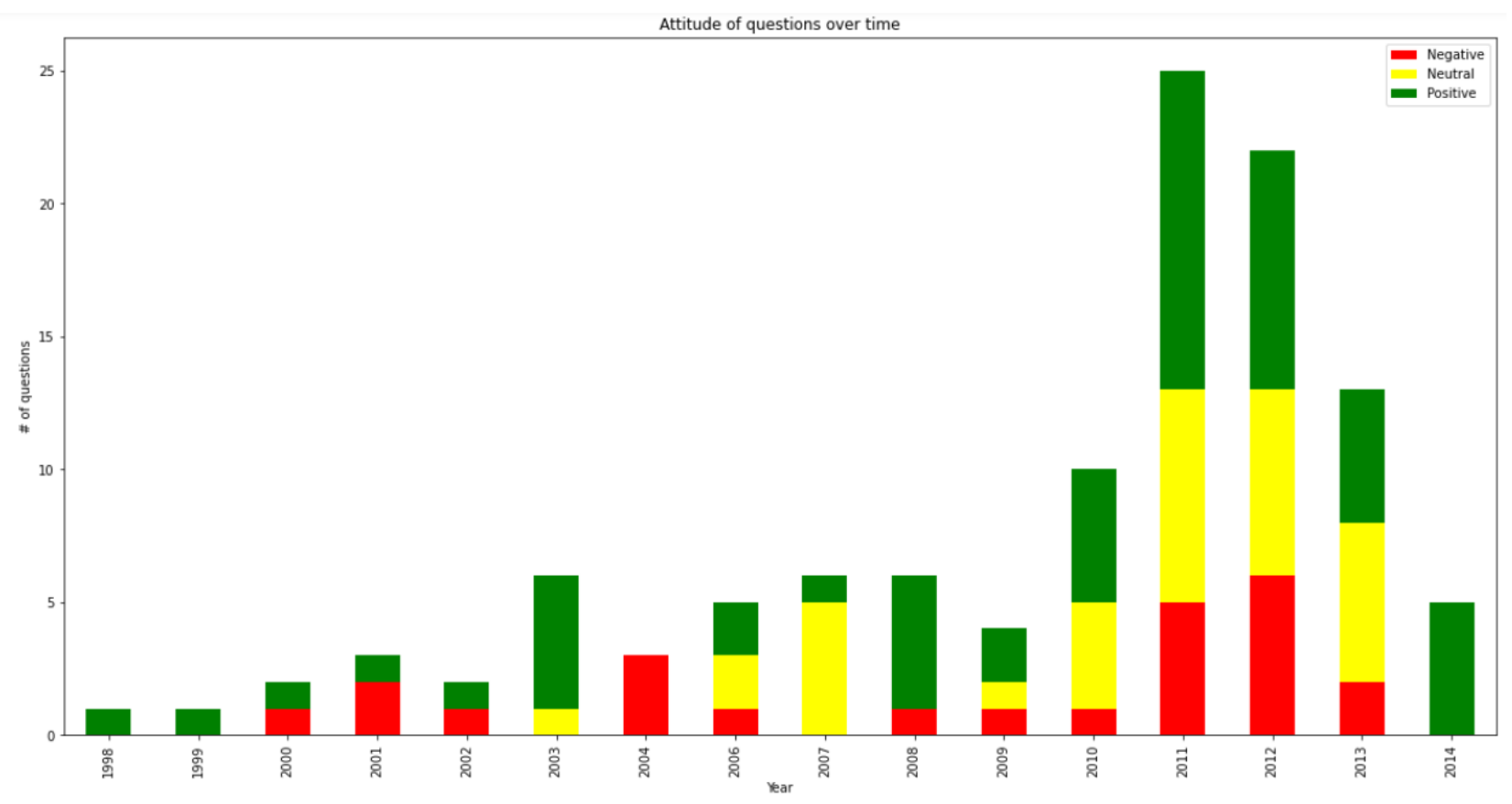

MEP Dominique Vlasto, Christian democrat party group (PPE), France attempted to promote offshore wind energy and asked the Commission whether the development of offshore wind farms was a priority to the EU Commission (Vlasto November 9, 2011). Oreste Rossi, a radical-Eurosceptic (EFD) from Italy promoted wind energy kites as a lower energy cost alternative to conventional wind farms (Rossi May 31, 2011). Nuno Melo from the Christian 
Democrats party group (PPE) Portugal was concerned that obtaining permits for windmill construction took too much time (Melo May 17, 2010).

Positive questions to the EU Commission were submitted by the Socialists, Christian Democrats, and the Green party groupings; however, different MEPs from the same party groupings submitted negative questions to the EU Commission. It seems that MEPs prioritized national interest when submitting questions regarding wind energy.

MEPs from the Green party groupings were the most skeptical towards the wind energy. Georgios Toussas from Greece representing the green party grouping (GUE/NGL) criticized wind energy in favor of the coal energy. According to Toussas, promotion of wind energy resulted mass layoffs and a surge of unemployment of $50 \%$ of young people in the coal region of Sulcis, Italy (Toussas December 5, 2011). This question submitted by Toussas from the Green group is significant because it shows he supported coal energy over wind energy and indicates that his national concerns trumped party ideology and EU concerns.

In two questions to the EU Commission, Michail Tremopoulos from Greece Verts/ALE noted that wind farms had been constructed in the Natura 2000 regions $^{4}$. Tremopoulos criticized the development of the wind farms and argued that newly built wind farms would disturb migratory birds and impair the ecological features of the special protection zone (Tremopoulos March 3 and 4, 2011). Alexandros Alavanos, GUE/NGL from Greece, also did not approve of the development of the wind park in Natura 2000, similarly emphasizing protected indigenous and migratory bird species" (Alavanos May 28, 2001).

Patricia McKenna from Ireland representing the Green party grouping (Verts/ALE) held Hibernian Wind Power Ltd responsible for several landslides that occurred during windmill

\footnotetext{
${ }^{4}$ Natura 2000 is a network of protected areas that covers Europe's most valuable and threatened species and habitats (The Natura 2000 protected areas network 2020).
} 
building process. McKenna did not directly object to the wind energy but asked whether the Commission was going to assist locals in studying the future project and any potential negative impact on the environment (McKenna March 2, 2004).

Concerns about migratory birds and damaged landscapes were the main reasons wind energy was criticized for, but some MEPs were skeptical about the winds energy's ability to replace fossil fuels and ensure low energy prices.

Independent Auke Zijlstra from the Netherlands referred to a leaked Commission memo that predicted a steep rise in energy prices over the next 20 years as a result of environmental regulations. Zijlstra was concerned that investment in wind and solar energy would double energy prices in these 20 years and asked the Commission several questions regarding the future of energy prices and employment. Zijlstra's main question was whether the Commission was still going to support current climate requirements if "scientific research demonstrates that there is no or only a slight correlation between carbon content in the atmosphere and temperature trends" (Zijlstra October 27, 2011).

Another independent from the Netherlands, Lucas Hartong, asked the Commission a follow up question about wind energy. Zijlstra and Hartong referenced a study published by Richard Tol, Professor of Economics at the University of Sussex and Professor of Climate Economics at the University of Amsterdam. According to Tol's study, wind energy would never be economically feasible. Zijlstra and Hartong inquired to the Commission how much money the Commission budgeted to subsidize wind farms (Hartong September 6, 2012).

MEPs from the Eurosceptic party groupings were also expressed similar concerns. For example, Tomasz Piotr Poręba, a member of Eurosceptic party grouping (ECR) Poland, criticized the lack of regulation of the growing number of wind farms in Poland. According to 
Poręba, constructing wind farms in Poland often involves breaking the law and a lack of respect for the landscape, environment, and citizens. He asked whether the Commission had conducted any studies on wind farms' negative impact on human health (Poręba April 11, 2012).

Zbigniew Ziobro also from Eurosceptic party group (EFD) Poland, noted that subsidizing wind farms was not the most prudent policy. Ziobro referred to findings of U.S. experts that wind energy was uncompetitive and costly to taxpayers (Ziobro February 18, 2013).

\section{Summary}

After the Fukushima disaster in 2011, MEP questions to the EU Commission regarding wind energy increased, and most of these questions were positive. Perception of wind energy among MEPs has been increasing incrementally since 1998, but the Fukushima nuclear accident incited MEPs to seek new energy sources that would replace nuclear energy. However, the Greens and the radical-Eurosceptic MEPs did not have a uniform opinion towards wind energy. For example, some Greens and the Eurosceptics from Greece and Poland were quite critical of wind energy. This observation suggests that MEPs from the Eurosceptic groups and some Greens have more flexibility when asking questions to the EU Commission. In a similar way, independent MEPs act in the interest of their home countries as they do not have to coordinate their questions with any party grouping.

\section{E. Solar Energy}

According to the EU Commission, the EU is a frontrunner in the use of solar power, and due to a solid industrial foundation, solar power has become one of the cheapest technologies for electricity generation worldwide (Solar Power, Published April 28, 2020). In comparison to other energy sources reviewed in this chapter, solar energy did not receive many questions between 1994 and 2014. However, number of questions towards solar energy increased in 2011 
after the Fukushima disaster and most of them were positive with few exceptions. The first Parliamentary questions about solar energy were asked in 2000 and since then have steadily increased in numbers, reaching their peak in 2012, please see Figure 5. "Solar Energy Dynamics in Written Questions to the EU Parliament".

Figure 5. Solar Energy Dynamics in Written Questions to the EU Parliament

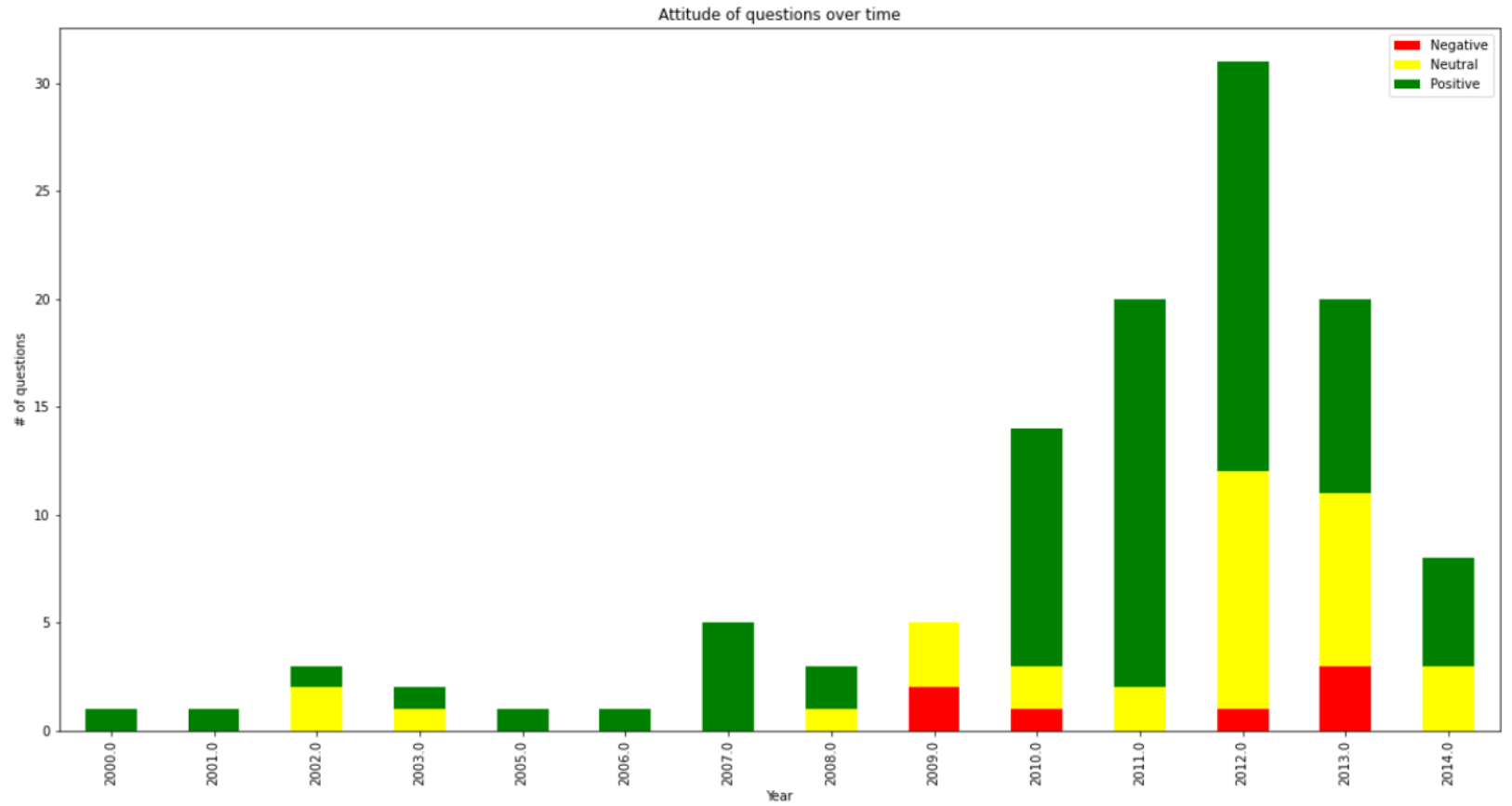

MEPs from Italy asked thirty questions to the EU Commission about solar energy and all these questions were positive or neutral. Regardless of their political parties, MEPs from Spain, Greece, Austria, and Germany were in favor of solar energy. Oreste Rossi, from the Eurosceptic party (EFD), Italy asked the Commission if it was going to support the development of new technologies by allocating more funds to research solar energy (Rossi September 28, 2010). However, another Eurosceptic (EFD) Morten Messerschmidt from Denmark was doubtful of renewable energy and asked the Commission whether they took for granted a utopian belief that climate problems could be solved solely on wind power and solar energy (Messerschmidt April 7, 2010). 
Licia Ronzulli from the Christian Democratic party group (PPE), Italy also asked the Commission about recent technology that could increase the efficiency of solar cells and the Commission's view of this technology (Ronzulli April 20, 2011). Sergio Paolo Frances Silvestris (PPE), Italy expressed concern that solar energy had lost its appeal in the EU, and in 2011 had lost almost half of subsidies among EU members. As the result of these changes, the solar sector faced financial difficulties, hence Silvestris asked the Commission how it was going to respond to the "crisis announced by companies in the solar panel sector" (Silvestris January $25,2012)$.

Other MEPs from Liberal, Christian Democrat, and the Socialist party groups were in favor of solar energy, yet other MEPs from the same party groupings had reservations towards solar energy. MEPs from the Socialist party grouping were especially concerned about solar panels manufactured in China. Marc Tarabella (S\&D) from Belgium was concerned about Chinese solar energy that was damaging to both US and EU solar energy markets. Tarabella asked the Commission if it was possible to impose sanctions on Chinese companies that were found to be dumping products on the EU market (Tarabella November 21, 2012). Monika Flašíková Tarabella from Slovakia (S\&D) was also concerned about the negative EU trade balance with China, and China's competition with the EU and US in production of solar panels (Tarabella January 10, 2013).

Lithuanian Zigmantas Balčytis (S\&D) from the Social Democratic party grouping wanted to know about the scale of solar battery production in the EU and the number of batteries imported into the EU from China. As with most of his counterparts, Balčytis supported solar energy and other renewable energy sources and hoped that solar energy would help the EU 
reach environmental targets and guarantee a sustainable supply of electricity (Balčytis May 30, 2013).

Werner Langen from Germany, David Casa from Malta, and Zuzana Roithová from Czech Republic representing the Christian Democrat party grouping (PPE) supported solar energy. As their counterparts from the Socialist party grouping Langen, Casa and Roithová were concerned about the European solar energy sector's competition with Chinese producers. Langen asked how the Commission was going to assist to European solar energy companies since imports from China lowering prices of photovoltaic equipment in European markets and causing European manufacturers to declare insolvency or lay off workers (Langen October 16, 2012).

Independent Csanád Szegedi from Hungary was the most enthusiastic about solar energy and was pleased to learn that the use of fossil fuels had decreased and that alternative energy sources had been increasing in EU countries. However, he noted that new Eastern European EU members were not always able to afford solar energy and did not have enough information about its benefits. Thus, Szegedi asked if the Commission had a plan that would help promote solar energy in Eastern Europe (Szegedi November 14, 2013).

\section{Summary}

MEPs from almost all the party groupings in the EU Parliament supported solar energy with a few slight exceptions. Several MEPs from S\&D were concerned about Chinese companies producing less expensive solar batteries and "dumping" them into EU markets. Only several MEPs were skeptical about solar energy and an interest in solar energy rose significantly in 2011 and 2012 after the Fukushima disaster. 
I suggest that the Fukushima disaster was a punctuating event that encouraged many MEPs to seek and support alternative energy sources that could replace nuclear energy and fossil fuels in the near future. However, MEPs started paying more attention to the solar energy before the Fukushima accident, and incrementally submitted more questions regarding wind energy to the EU Commission.

\section{Conclusion}

These case studies on nuclear, hydraulic fracturing, coal, wind, and solar energy allow me to conclude that PET is applicable in studying written questions that MEPs submitted to the EU Commission. I suggest that the Fukushima nuclear disaster created an opportunity for the energy policy change in the EU Parliament. The accident triggered MEPs to pay more attention to nuclear, coal, hydraulic fracturing, wind, and solar energy, but did not significantly change MEPs' behavior as their perceptions towards these energy sources were already changing incrementally.

After the Fukushima accident, MEPs from all the political party groups submitted more negative questions to the EU Commission regarding nuclear energy, but after 2011 the number of these questions decreased again. Further study of the written questions that MEPs submitted to the EU Commission would give a better idea how significant Fukushima was to nuclear energy policy change in the EU Parliament. Before the accident, nuclear energy was perceived as a better alternative to coal, but after most MEPs perceived this energy source as a security issue.

The data I collected suggest that coal energy from 1994 to 2014 did not have a positive image in the EU Parliament and that its image among MEPs had been declining incrementally over time. In the time period of my analysis the framing of coal energy did not significantly 
change and it was perceived as both an internal safety issue and an environmental issue, since coal power plants and coal mining were contributing to global warming.

The image of hydraulic fracturing policy began positively, but also declined in an incremental way as its potential negative consequences became more apparent. At the beginning of my study, hydraulic fracturing was perceived/framed as an issue of economic security, but has shifted to an issue of safety.

The positive view of the wind and solar energies have been incrementally increasing in the EU Parliament. The Fukushima accident prompted MEPs to ask more questions regarding wind and solar energies, but in 2012 the number of questions has decreased suggesting incremental changes. The policy framing of wind and solar energy did not change in the time period of my study as they were mostly perceived as tools to prevent global climate change and to ensure energy security.

The data that I have collected also can be used to explain behavior of the political party groups in the EU. For example, the Christian Democrats did not criticize coal energy as much as their counterparts, which is consistent with the Christian democrats' priorities to focus on national security. The Greens were very critical of coal energy, with a few exceptions, while MEPs from Social Democrat groups expressed different positions: some criticized coal, yet some were concerned about lost wages of the coal miners and EU anti-coal policies. Hydraulic fracturing received positive reviews in the early years of operations, especially from Christian Democrats and radical-Eurosceptics from Poland, but the Social Democrats and Green Parties were critical of hydraulic fracturing. MEPs generally wrote favorable questions about wind and solar energy sources, but some MEPs from the Greens and Eurosceptic party groupings were also critical of some wind and solar parks due to environment concerns. Liberals and Christian 
Democrats in some cases were concerned about the feasibility of the renewable energy sources, but in general were supportive of wind and solar.

In most cases, political party groupings submitted questions to the EU Commission within their party lines: The Greens were critical of coal when Christian democrats did not fiercely criticize nuclear, coal, and hydraulic fracturing. The exception was the radicalEurosceptic party groupings that kept allegiance to their home countries. The same is true for the liberal party groupings and the independent members who are not associated with any political party grouping. 


\section{Chapter 4. Energy Policy in the Lithuanian Seimas}

In this section I examine energy policy developments in the Lithuanian Parliament Seimas from 1992 to 2016, including an overview of the major political parties in Lithuania and their evolution. I am interested to find whether punctuated equilibrium theory (PET) is applicable in studying energy policy dynamics in the Lithuania Seimas. Frank Baumgartner and Bryan D. Jones (2009) argue that PET is not limited to study only pluralist systems as in the U.S, but can also be suitable to study other countries because punctuated dynamics is a very general feature. They argue that large-scale policy changes can be associated with the electoral change (Baumgartner, Jones 2009, 11). Based on this assumption, I expected to find that right-leaning political parties such as the conservative (Homeland Union-Lithuanian Conservatives ) would support Lithuania's membership in the EU, but I also expected that they would support nuclear, coal, gas, and any energy source that would help Lithuania secure energy independence from Russia. I also anticipated that left-leaning political parties such as the Social Democrats would advocate for renewable energy sources. In other words, I expected to find different energy policies produced by these two-party blocks. However, after conducting my analysis, I discovered that these two different party groups ultimately produced similar energy policies.

To assess Lithuania's political party perceptions towards energy policies, I collected and investigated 250 laws that were passed by the Lithuanian Seimas from 1992 to $2016^{5}$. Elections to the Lithuanian Seimas occur every four years, and almost after each election, party composition in the Seimas changes. In 1992 the Social Democrats ${ }^{6}$ had a majority. In 1996, political power went to the Conservatives, then returned to the Social Democrats in 2000. The

\footnotetext{
${ }^{5}$ I analyzed only laws that were passed in Lithuanian Seimas from 1992 to 2016, but I did not analyze laws that were introduce, but not passed during this time period.

${ }^{6}$ At that time the Social Democratic were called the Democratic Labor Party (LDDP)
} 
laws I investigate are plotted in four years increments to represent a four-year Seimas session. I expected to find significant differences in the laws that were passed by the Conservative Seimas versus those passed by the Seimas where the Social Democrats had a majority, but the differences were minor and overall the Lithuania parliament pursued a consistent direction favoring energy independence from Russia.

Given Lithuania's long historic battle to become independent I expected a lively and contentious political environment. However, diversity of views on the matters of the day did not translate to the diversity of opinion on energy independence and energy security. Political parties across the spectrum, right, left, and populist, compete for seats in the Lithuanian Seimas, forming coalitions across a wide range of issues. Most political candidates have different priorities for how the country is supposed to be run: however, once they are elected and form a majority in the Seimas, they have one goal in common: seeking protection and security from the looming specter to the East - Russia.

For an "energy island" like Lithuania, energy security equals national security. After facing severe energy blockades from Russia since the collapse of the Soviet Union and the dawn of modern Lithuanian independence, policy makers from all the political parties in the Seimas have all sought membership in both the EU and NATO as a means of ensuring energy security and independence. EU membership was seen as so critical to Lithuania's independence that members of all the major political parties and the majority of Lithuanian policy makers agreed to the EU's pre-accession condition that Lithuania must close down the Ignalina nuclear power plant, despite the fact that this station was a major source of reliable power for Lithuania's energy grid. 
Therefore, in this chapter, I discuss how all the main Lithuanian political parties in power from 1992 to 2016, despite their political and policy diversity, supported EU membership and agreed to close the Ignalina nuclear power plant. Because of nuclear energy's central role in Lithuania's historic energy grid, the impacts of shutting down the Ignalina power plant, and prospects of a new modern nuclear power plant which was defeated in 2012 referendum, nuclear power has been at the center of many of the energy policy laws that were passed in Lithuania from 1992 to 2016.

Political scientists studying Lithuania's political parties, energy policy, and journey to join the European Union all recognize that Lithuania aggressively sought to join the EU and NATO and emphasize that Lithuania is simultaneously afraid of Russia but also in need of Russian energy (Zygimantas Vaiciunas 2009, Nerina Miliauskaite 2014, Margarita Mercedes Balmaceda 2013, Randall Newnham 2010, Agnia Grikas 2012, Tomas Janeliunas and Arunas Molis 2006, Arunas Molis and Tomas Vaisnoras 2014, and James S. Corum 2013). However, past studies have primarily investigated Lithuania's energy policy from a comparative perspective, comparing Lithuania with the other two Baltic states (Latvia and Estonia), or with former satellite states of the Soviet Union. Little attention has been given to analyze how this constant "fear of Russia" is reflected in the laws passed by the Seimas or how changing majorities (from right-leaning to left-leaning, or to a populist majority) in the Seimas have impacted Lithuania's energy policy. The purpose of this chapter is to address these gaps in the literature by applying PET.

Baumgartner and Jones suggest that some policy changes occur incrementally when some occur after the punctuating event or due to electoral changes. Hence I am interested to find 
whether Lithuanian energy policy underwent punctuating events or incremental changes, and whether "fear of Russia" factored into Lithuania's energy policy development.

The literature review that follows is divided into two sections: the first section identifies the main energy sources and issues present in Lithuanian energy policy, and the second section discusses the diversity and development of Lithuania's political parties and what impact (if any) these parties have had on Lithuania's energy policy.

\section{Lithuania's Energy Policy}

Margarita Mercedes Balmaceda (2013) investigates energy policies in the former Soviet Union countries with a focus on Ukraine, Belarus, and Lithuania. Balmaceda notes that after the collapse of the Soviet Union, Russia started to use energy as a foreign policy tool (Balmaceda 2013, 42). In April of 1990, while still officially part of the Soviet Union, Lithuania declared its independence from Russia and immediately faced a three-month energy blockade from Moscow. This blockade was intended to discourage Lithuania's leaders from pursuing independence. At first, the energy blockade seemed successful, and Lithuania issued a six-month moratorium of the independence declaration in exchange of the lifting the blockade. However, this blockade had an unintended consequence for Russia: the blockade gave Lithuania's political elite an understanding that energy policy is a crucial national issue. According to Balmaceda, eventually the Lithuanian political elite reached consensus that Lithuania needs to take whatever necessary measures "in order to rejoin Europe as soon as possible" (Balmaceda 2013, 2015).

Soon after it regained its independence, Lithuania (together with several other Soviet satellite states) expressed an interest in joining the European Union and NATO, but the EU membership happened to have a high price when the EU demanded that Lithuania decommission the Ignalina's nuclear power plant. Closing the Ignalina's nuclear power plant was a non- 
negotiable condition for EU accession, and Lithuania pledged to close the first reactor by 2005 and the second one in 2009 (Balmaceda 2013, 215). Lithuania signed the pre-accession agreement without “preparing Lithuania’s energy system for life after Ignalina’s full decommissioning in 2009” (Balmaceda 2013, 224). Later Lithuania tried to renegotiate a new agreement with the EU regarding decommissioning Ignalina's nuclear power plant, but these attempts were not successful.

Balmaceda argues that Lithuania had extremely high expectations from EU membership, but these expectations were not fulfilled. However, EU membership helped Lithuania to implement energy efficiency guidelines and move to a greater use of renewable resources. The EU also supported European priority infrastructure development projects such as the Baltic Energy link (Balmaceda 2013, 256).

Neringa Miliauskaite (2014) discusses similar energy related issues and emphasizes that the "old Europe" is more concerned about the environment side of energy issues which is a contrast to Lithuania's priorities: high energy prices and tense relations with Russia. In contrast, the "old EU members" do not share the same energy concerns as Lithuania because they have more options to access energy due to their location, and/or have better relations with Russia. According to Miliauskaite, Lithuania and the other newer EU members cannot "afford" to use renewable energy resources due to high energy prices (Miliauskaite 2014, 26). Miliauskaite argues that increasing energy prices threatens the survival of Lithuanian citizens during the winter thus Lithuania needs a quicker solution to address the energy prices that are a focus of discussion both in the Lithuanian government and among ordinary Lithuanians (Miliauskaite 2014, 28). Unfortunately, the closure of the Ignalina's nuclear power plant made Lithuania's bad energy situation even worse as it become more dependent on Russian gas (Miliauskaite 2014, 1). 
Like other researchers, Miliauskaite identifies the fact that Lithuania is heavily dependent on Russian energy and suggests it adopt the EU Central Asia Strategy. Miliauskaite compares Lithuania's energy situation to the energy situation of the Central Asian countries (Kazakhstan, Azerbaijan, Turkmenistan, Georgia, and Armenia) and suggests cooperation with these countries in particular with Kazakhstan and Azerbaijan which are the main suppliers of gas and oil (Miliauskaite 2014, 63).

Balmaceda and Miliauskaite discuss Lithuanian energy policies from a geopolitical perspective without investigating laws that were passed in the Lithuanian Seimas. They acknowledge that tense relations with Russia caused additional energy related problems for Lithuania, yet they do not investigate how these energy problems were reflected in the Lithuanian Seimas.

Agnia Grikas (2016) also studies Lithuanian energy issues from a comparative perspective and looks for similarities and differences between Lithuania, Latvia, and Estonia. Grikas focuses on Lithuania, Latvia, and Estonia's energy policies and their relationship with Russia after these three Baltic states declared independence. Grikas argues that old grievances with the Soviet Union impact current policies towards Russia. In general, the Baltic states perceive Russia as threat, but most often Lithuania stands out as the harsher critic of Russia (former Soviet Union). For example, of all the Baltic states, only Lithuania has never accepted any official or unofficial invitations from Moscow to attend the Victory Day celebration. Victory Day is one of the most important holidays in Russia because it marks the defeat of Nazi Germany by the Soviet Union in the Second World War. However, for the Baltic countries this day marked the beginning of the Soviet occupation. It is important to note that invitations to 
attend celebrations in Moscow were rejected by leftist, non-partisan, and the center right Lithuanian presidents (Grigas 2016, 136).

Grigas notes that the Baltic-Russian energy relations are based on dependency, vulnerability, and fear, hence the Baltic states were hoping to find protection in EU and NATO memberships. In the early 1990s Russia still relied on the Baltic states for transit of its energy products to Western markets, but in the 2000s, Moscow cut-out ties with them for transit business. As the result, the Baltic states remained heavily dependent on Russian energy, and the question of energy security become priority for the Baltic countries (Grigas 2016, 50). According to Grigas, Lithuania was most outspoken in the effort to reduce Lithuanian and EU dependency on Russian energy. Member of the European Parliament Vytautas Landsbergis aimed to create a subcommittee on energy security in the EU Parliament. Lithuania also planned for a 1000mv power link to Sweden and a separate link to Poland, but by 2012 not much progress was made on these projects. Lithuania also planned to build a new nuclear power plant, but this planned stalled due to domestic disagreements, lack of interest among investors, and disagreements between Vilnius and Warsaw. Grigas also notes that Estonia and Latvia rarely initiated multilateral proposals in the energy security area (Grigas 2016, 52).

Although, Grikas does not investigate laws passed in the Seimas and in the respective Latvia and Estonia's Parliaments, she stresses that Lithuania presidents from the different political parties held uniform policy towards Russia and refused to attend Second World War celebrations in Moscow. Grigas also emphasized that from all three Baltic states, Lithuania most focused on energy security and energy independence and these Lithuania's energy goals remained consistent over time. 
Randall Newnham (2010) supplements Balmaceda's argument and adds that the Soviet Union and present Russia tried to control the neighborhood countries by making Russian energy indispensable throughout Eastern and Western Europe. But unlike Grigas, Miliauskaite, and Balmaceda, Newnham discussed the actions the Soviet Union took to ensure that the Baltic States, and other soviet satellite countries stay under its influence.

During the 1950s and 1960s the Soviet Union tried to link its Warsaw Pact allies economically under the Council for Mutual Economic Assistance (CMEA), but the CMEA members felt economically exploited by the Soviet Union. The Soviet Union provided subsidies for the huge energy-hungry industries which were built in the countries of Soviet influence. The loyal states, which experienced political problems were helped with even more subsidies; in contrast, not so loyal states had to face consequences for their actions (Newnham 2010, 135). After Lithuania's energy blockade in 1990, another blockade occurred in July of 2006 when Russia shut down the pipeline which supplied oil to the Mazeikiai refinery. This incident occurred after Lithuania decided to sell the refinery to a Polish company PKN rather than accepting offers from Russian rival companies (Newnham 2010, 142).

Besides focusing on Russia’s energy blockades, Tomas Janeliunas and Arunas Molis (2006) discuss other energy security related issues that isolated Lithuania even more. Energy dependency on Russia has been an important policy issue for Lithuania, and that energy security become even more important in 2005. In 2005, Russia and Germany agreed to construct a gas pipeline which would cross the Baltic Sea but bypass the Baltic countries and Poland. This agreement raised concerns in Lithuania (and in the other Baltic states, as well as Poland) and made them believe that Russia intentionally excluded Lithuania from accessing gas (Janeliunas, Molis 2006, 200). 
Janeliunas and Molis point out that the energy blockade from Russia in 1990 taught Lithuania a lesson and galvanized Lithuania's political elite to be prepared for future blockades and energy crises. Soon after the blockade, the Lithuanian political elite decided to build the Butinge oil terminal that would help to import oil by alternative means. The construction of the terminal cost Lithuania 350 million USD, but it has already paid itself off (Janeliunas, Molis 2006, 206). According to Janeliunas and Molis, Lithuania had high hopes for the creation of the EU Common energy policy that would control energy demands, create the common compatible energy market among the EU countries, and diversify energy sources and routes (Janeliunas, Molis 2006, 215). The Lithuanian political elite also attempted to convince the EU that closure of Ignalina's nuclear power plant would be detrimental not only to Lithuania, but to the entire EU. Lithuania also tried to get financial assistance from the EU that would help to compensate a possible shortfall in energy after the powerplant was closed (Janeliunas, Molis 2006, 217). Similar to Balmaceda and Grigas, Janeliunas and Molis stressed that Lithuania had high expectations from EU membership, yet not all of these expectations were fulfilled. However, EU membership provided Lithuania with unique opportunities to improve its energy sector.

As other researchers discussed in this literature review section, Janeliunas and Molis suggest that the energy blockades from Russia, and Lithuania's exclusion from the accessing the gas pipeline in the Baltic Sea incited its policy makers to look for alternative energy solutions. Butinge oil terminal and the EU membership with a hope for the common EU energy policy were these solutions.

Zygimantas Vaiciunas (2009) argues that energy security is a priority for Lithuania and that it should take the initiative in shaping the EU's energy policy. In 2009, Vaiciunas recognized several factors that made Lithuania vulnerable. First, 90 percent of Lithuania's oil 
and 100 percent of natural gas comes from Russia. Second, Lithuania, Latvia, and Estonia are "energy islands" due to lack of an energy infrastructure that would connect them to Western Europe. Third, Lithuania does not have an opportunity to implement energy import projects from alternative countries without assistance. Finally, the closure of Ignalina's nuclear power plant would increase energy dependency on Russia (Vaiciunas 2009, 94).

Researchers cited thus far have discussed Lithuania's energy struggles, energy blockades imposed on Lithuania by the Soviet Union, and Lithuania's desire to join the EU and NATO. Arunas Molis and Tomas Vaisnoras (2014) study is different in a way because these researchers discuss Lithuania's leadership in the EU and Lithuania's contribution in developing EU energy policy.

In 2013, Lithuania took over presidency in the EU Council in 2013 and it was determined to use the presidency to reduce Lithuania's energy isolation. Lithuania has accomplished some important energy goals, including creation of common EU electricity and natural gas markets. Molis and Vaisnoras argue that common electricity and gas markets would reduce Lithuania's energy isolation and create the precondition for a common EU energy policy (Molis, Vaisnoras 2014, 31).

Thanks to Lithuania, EU member states agreed to expand fair energy competition regulations. Lithuania also worked in creating an opportunity for the strategically important countries from the South Caucasus, Central Asia, and MENA regions to join the old Energy Community Treaty (ECT) (Molis, Vaisnoras 2014, 26, 27).

In addition to leadership in the EU Council, Lithuania took an initiative in other energy related projects outside of the EU. In 2012, NATO opened the Vilnius-based NATO Energy Security Centre of Excellence (ENSEC COE). Representatives from all the NATO countries 
participate in the NATO ENSEC COE activities, but Lithuania contributed the most in creating this institution and, according to the NATO ENSEC COE agreement, its director will always be a Lithuanian military officer. NATO ENSEC COE provides Lithuania with a unique possibility to have an impact on NATO's activities in the domain of energy security (Molis, Vaisnoras 2014, 29).

Molis and Vaisnoras discuss Lithuania's accomplishments in the European Council and NATO, but neither they nor the above reviewed authors discuss energy laws that were passed by the Lithuanian Seimas. Most of the researchers acknowledge that Lithuania has always had turbulent relations with Russia, but do not discuss how these turbulent relations have changed over time or are reflected in the Seimas' laws.

Similar to Molis and Vaisnoras, James S. Corum (2013) stresses Lithuania's goal to gain EU and NATO membership. He studies the Baltic States and emphasizes that Lithuania, Latvia, and Lithuania expressed interest in joining NATO and the EU once they regained independence. Even before becoming the full NATO members, the Baltic states strongly supported the U.S.-led coalition in Iraq and sent troops to serve under U.S. command in the Iraq War. Lithuania, Latvia, and Estonia were also active in Afghanistan, and all have contributed hundreds of fighting troops without reservations to serve under U.S. and NATO command (Corum 2013, 2, 3).

Corum notes that the Baltic states together with Easter European NATO members successfully influenced the new NATO strategic concept that would recognize Russia as a threat. In 2008, Russia invaded Georgia and this invasion surprised older NATO members, helping the Baltic states to get reassurance that Article 5 of the Washington Treaty was still relevant and key to NATO's core policy (Corum 2013, 20). In the area of energy security, Corum distinguishes Lithuania as being the most vulnerable to pressure from Russia because it depends fully on 
Russia for oil and gas supplies and must purchase electricity from Belarus and Ukraine (Corum 2013, 21).

Balmaceda, Miliauskaite, Newnham, Grikas, Molis and Vaisnoras, Newnham, Corum, and the other authors distinguish several main caveats regarding Lithuanian energy policy:

- Lithuania's dependency on Russian energy threatens Lithuania's energy security,

- Energy blockade of 1990 and the other energy related incidents proved Russia to be unreliable partner, and as the result Lithuania has been looking for protection to the Western organizations such as the EU and NATO.

- Lithuania had to close Ignalina's nuclear power plant to fulfil the pre-accession obligations to the EU.

However, there is little discussion in this literature about whether and how these main Lithuanian energy concerns translate to laws and other Seimas' decisions. Most researchers discuss Lithuania as a monolithic unit without considering political parties and how elections to the Seimas change parliament's governing majority every four years. In the following section, I discuss Lithuanian political parties and their development. Lithuania has many political parties, but the main political forces that dominated Lithuania's political life since 1990 were the Conservatives (Homeland Union-Lithuanian Conservatives) and the Democratic Labor Party (LDDP).

These two parties led coalition negotiations with the other political parties that were elected to the Seimas but did not receive enough seats to form a governing majority by themselves. The Populist political parties emerge before each election cycle with their "antiestablishment" rhetoric, but once in Seimas, they join an establishment party they just criticized on the campaign trail and pursue energy security and energy independence. Most of the political 
parties in the Seimas come to a consensus that Lithuania's energy security rests with the EU and NATO.

\section{Introduction to Lithuania's Political Parties}

According to the model that is used to classify Wester European democracies, Lithuanian parties can be placed on the traditional economic left-right scale and on the axis of social liberalism and social conservatism. However, this classification did not reflect the real political situation in newly independent Lithuania where the structure of the party system was mainly shaped by the dominant communist - anti-communist or East-West cleavage (Ramonaite 2010, 125). For a decade, the Homeland Union-Lithuanian Conservatives (the Conservatives) party was perceived as anti-communist, pro-western party that did not approve cooperation with Russia. The Homeland Union-Lithuanian Conservatives always supported Lithuania's integration into the EU and NATO and was promoting energy security and energy independence. On the other hand, the Democratic Labour Party (LDDP that changed its name to the Social Democrats) was for a long time perceived as the party of former communists and sympathizers of the former Soviet Union. Unlike socialist political parties in the Western Europe, the Lithuanian LDDP represented the interests of nomenclature and big business, rather than pursuing equality and justice for all (Ramonaite 2010, 75).

Later the prominence of East-West, communist-anticommunist cleavages started to disappear and in the 2000s, social-economic aspects become more relevant. Although the LDDP did not advocate for significant reforms and supported a "friendly" relationship with the former Soviet Union, once in power the LDDP leaders embraced EU and NATO integration and supported energy independence from Russia (Ramonaite 2010, 75). However, the LDDP and the Social Democrats were always perceived as not being "strong” on Russia and often emphasized 
different priorities in their political slogans. For example, in their respective political campaigns to the EU Parliament elections of 2014, the Homeland Union-Lithuanian Conservatives advocated for a "secure Lithuania and strong Europe" when the slogan of the Social Democrats was "the individual is the most important" (Tumelyte 2015, 33).

As a general rule, the populist parties of Lithuania criticized the "establishment", but after getting a majority in the Seimas, they did not stop Lithuania's pursuit of energy independence. However, the perception that the LDDP sympathized with the former Soviet Union is not backed up by studying energy laws passed by the Seimas in the time when the LDDP was in power.

Kjetil Duvold and Mindaugas Jurkynas (2013) argue that all Lithuanian political parties from across the spectrum emphasize energy security and energy independence. The fact that Lithuania pays the highest price for Russian gas imports in the Baltic states and has no alternative sources for imports of fossil fuels other than Russia makes it impossible for any political party to suggest otherwise. According to Duvold and Jurkynas, it would be perilous for any politician to break the mantra of energy independence, because suggesting otherwise would lead to accusations of 'being a sell-out, disloyal, corrupt, and in the Kremlin's pocket (Duvold, Jurkynas 2013, 140). Duvold and Jurkyna's study suggests that the main political parties in Lithuania pursue energy independence from Russia, and that energy policy is one of the most important issues discussed in the Seimas, but Duvold and Jurkynas do not analyze laws passed by the Seimas to test their arguments.

Duvold and Jurkynas divide development of Lithuania's parties into three stages from 1990 to 1998, from 2000 to 2004, and from 2008-beyond (Duvold, Jurkynas 2013, 126-130). In this section, I adopted their proposed phases of the development of 
Lithuania's political parties as these phases accurately reflect Lithuania's political situation. Many of the political parties emerged in these development stages, but once elected to the Seimas, these political parties congregated into the two major party blocks: the Conservatives and the Social Democrats. Three development stages of the Lithuanian political parties suggest diversity on variety of issues, but when it comes to the national security, energy security and EU and NATO memberships, political parties that form majority in the Seimas pursue these goals.

However, the Conservatives and the Social Democrats differ from each other in other aspects. In the early stages of Lithuania's political party development, the Conservatives strongly supported privatization while the Social Democrats were less enthusiastic and argued that certain companies (related with transportation and energy) should not be privatized (Kiveris 2006, 106). The Conservatives did not pay much attention to rural issues while the Social Democrats stressed the needs of people who live in the countryside. The Conservatives argued for the development of private business by providing them with the tax benefits while the Social Democrats argued for the progressive taxes (Kiveris 2006, 107).

It is also important to mention that Lithuania's political arena is full of different political parties that emerge before each of the elections, but not all of these political parties are significant, and many of them stay in the political periphery. In this dissertation, I focus on the main political party groupings that are presented in Table 1. "Lithuanian Party Groupings 1992-2016".

First Phase: Political parties from 1990 to1998 marked formation of Lithuanian political party system. In early 1990s two major political groupings emerged from the Popular 
Movement (Sajūdis) and the former Communist Party of the Soviet Union (Duvold, Jurkynas 2013,126). The descendant of Sajūdis was Homeland Union-Lithuanian Conservatives with Vytautas Landsbergis as their leader, and the descendent of the Communist Party was the Democratic Labour Party (LDDP) with their leader Algirdas Brazauskas. Around that time, historical political parties started reemerging, and new political parties were created. These political parties were the Humanism and the Green parties, the Liberal and the Peasant Union, the Independence Party, the Republicans, the Democratic Labor Union, and the Liberal Union (LS) and the Centre Union (CS), but despite these emerging new political parties, Sajūdis and the former Lithuanian Communist Party (LKP) and their successors would dominate Lithuanian political landscape for the years to come (Krupavičius 1996, 44, 46, Duvold, Jurkynas 2013, 127).

In the elections of 1990, Sajūdis won an absolute majority and formed the government, but soon after the victory members of Sajüdis were not able to overcome disagreements regarding economic challenges and internal politics. Although Sajūdis paved the way to the independence, later it was held responsible for Lithuania's economic problems. As the result of these economic struggles, a new election to the Seimas was called in 1992, with a referendum to confirm Lithuania's constitution (Lithuania, Parliamentary Chamber: Seimas). Dissatisfaction with Sajūdis resulted in a victory for the DLP (predecessor of LDDP) party that gained 73 seats in the Lithuanian Parliament while Sajūdis was second with 28 seats (Ramonaitè 2010, 69).

Although the LDDP's leader Algirdas Brazauskas was a former First Secretary of the Communist party of Lithuania, he and the LDDP continued pro-Western Reforms which eventually led to Lithuania's NATO and EU memberships (Tamošaitis 2019, 97). The fact that Lithuania become a member of NATO and the EU suggests that the left-leaning political party 
and their leader Brazauskas embraced the EU and NATO membership in the same way as the Conservatives.

Political analysts distinguish several reasons for which Sajūdis was defeated in 1992 elections. One of them was growing disappointment with the challenges that independent Lithuania had to face. Citizens of Lithuania were not prepared to pay high market prices for fossil fuels, which become a big issue for a country that did not have sustainable energy resources. The electorate hoped that Brazauskas and the newly assembled LDDP would maintain friendly relations with Russia and would help negotiate better prices for their fossil fuels (Tamošaitis 2019, 99). Tamošaitis arguments suggest that energy prices were always a top priority for Lithuania's policy makers and for the public.

It is important to stress that major Lithuanian political parties embrace energy security as a top priority. Once Lithuania's independence was recognized by the international community, Lithuania and the other Baltic nations expressed interest in joining NATO. In 1993, all political parties signed a letter to the Lithuanian president urging him to seek NATO membership (Partiju Keipimasis, 1993). A month later, after losing the elections to the Parliament, right-leaning political parties in opposition sent a memorandum to the newly elected president Brazauskas reminding him not to abandon national policy and to seek NATO membership (Memorandumas 1993). Although left-leaning political parties are perceived as more friendly to Russia, this is not the case in matters of national security.

When the left-leaning political parties came to power in 1992, the left-right dimension was not fully formed in Lithuania. In the early 1990s, the left and right divide reflected the dominant communist and anti-communist cleavage and rhetoric rather than a socioeconomic and ideological spectrum. The best representation of a left party was the ex-Communist Lithuanian 
Democratic Labor Party (LDDP), while the Homeland Union-Lithuanian Conservatives and the Lithuanian Christian Democratic Party represented the right political spectrum (Ramonaite 2010, $80)$.

The parliamentary elections to the Seimas in 1996 returned power to the right. The conservatives with Vytautas Lansdbergis as their leader won an absolute majority of the seats in the Seimas. The conservatives formed a majority government with the Christian Democrats and the Center Union. Center Union was a new political party that emerged in 1993 as alternative to the Conservatives. The emergence of the Center Union suggests that voters gradually become fed up with only two political forces (Duvold, Jurkynas 2013, 128)

Prior the 1996 elections, the LDDP received criticism for political scandals and economic stagnation that the LDDP controlled government was not able to improve. The Homeland UnionLithuanian Conservatives promised to address the struggling economy, fight corruption, and make sure that Lithuania is accepted into NATO and the European Union (Lithuanian

Parliamentary Chamber: Seimas). The promises made by the Homeland UnionLithuanian Conservatives suggest that the EU and NATO memberships have been the main topics among Lithuania's policy makers and the public in newly independent Lithuania.

The LDDP defeat in the 1996 elections encouraged cooperation between it and the historic Social Democrats party (LSDP). After Lithuania restored its independence in 1990, these two parties competed for the electorate, and after a strong LDDP performance in the 1992 elections, the LDDP was able to form the government by itself without LSDP help. However, a changing situation after the 1996 elections encouraged these parties to cooperate (Janušauskienė 2011, 35). 
During this stage, the left-leaning (LDDP, LSDP), and the right-leaning (HULC) political party blocks dominated the political arena without facing major competition from the other smaller political parties. Some new political parties emerged in the coming decades, but they joined LDDP, LSDP or HULC party block.

Second Phrase: Political Parties from 2000 to 2004: During the elections of 1992 and 1996, five main political parties attempted to get into the Lithuanian Parliament. The winners of 1992 and 1996 elections were right- and left-leaning successors of Sajüdis movement, and after the elections of 1996, it was believed that the political party system in Lithuania had stabilized (Janušauskienè 2011, 26). However, the dynamics of political parties after the elections of 2000 changed dramatically with the Homeland Union-Lithuanian Conservatives' loss of a majority in the Parliament. The left (LDDP, LSDP), and the right (HULC) political dimension was supplemented by several new political parties: The New Union (Social Liberals) and the Liberal Democratic Party (LDP). The LDP's (later renamed Order and Justice TT) leader was Rolandas Paksas and he rose to_power thanks to unsuccessful sale of the Lithuanian oil company Mažeikių Nafta to the American company Williams International. (Duvold, Jurkynas 2013, 129).

Paksas was a former member of the Christian Democrats and briefly served as a prime minister in 1999 but resigned in protest over the Williams deal. Williams International attempted to transform Mažeikiu Nafta into a profitable business, but Russia's oil producer Lukoil hindered their operations. Lukoil desired a controlling interest in the Lithuanian company and temporarily stopped sending oil supplies to Mažeikiu Nafta as an objection to the Williams deal (Malinauskas, 2014). 
Mažeikiu Nafta was not a popular deal among Lithuanian people and the Homeland Union-Lithuanian Conservatives party that had majority in the Seimas was blamed for this deal (Wines 2002). Mažeikiu Nafta matters got even worse after Williams International sold their shares to the Yukos Petroleum of Moscow which was Russia's second-largest oil producer at that time. After this transaction, Yukos gained control of 54\% the refinery's shares (Wines 2002). The Mažeikiu Nafta deal suggests that Lithuanian Conservative party attempted to escape from the Russia's influence, however, this attempt was not successful. Russian company Yukos gained control of majority of Mažeikiu Nafta shares, and in addition to that, a new populist, antiestablishment political party, the LDP, was formed.

Another new political party that was created before the 2000 elections was called the New Union. The New Union's leader was a former candidate for president and a prosecutor, Artūras Paulauskas. The New Union party participated in 2000 elections finishing third and gaining twenty-eight seats in the Seimas (Ramonaite 2010, 71).

Lithuanian Conservatives lost support of their electorate and created an environment for the Liberal Democratic Party and for the New Union to emerge. The success of these two new parties was attributed to the popularity of their leaders: Rolandas Paksas and Arturas Paulauskas.

The LDP did not have a clear political ideology and appealed to people who were disappointed with the political parties of that time. After their success in the parliamentary elections LDP and the New Union formed the coalition which lasted only for a year (Ramonaite 2010, 73).

After the unsuccessful LDP - New Union's coalition, the LDDP merged with Social Democrats, the Russian Union, and New Democracy to form a left-leaning Social Democratic Coalition led by Algirdas Brazauskas (LSDP Istorija). Although the 2000 elections to the Seimas 
brought new political parties, these new parties formed a coalition with the left leaning LDDP. As I have already mentioned in the beginning of this sub-chapter, Brazauskas was the former leader of the Communist party of Lithuania hence he and the LDDP party were perceived as proRussian. However, the LDDP and Brazauskas pursued membership in the EU and NATO. Years of relative stability was disturbed by an unexpected outcome of the presidential elections. Chairman of the LDP Rolandas Paksas participated in the elections and beat the incumbent Valdas Adamkus. Although, Paksas did not enjoy his victory for long time; at the end of 2003 Paksas was accused of collaborating with the Russian mafia and illegal arms dealers. As a consequence, Paksas was impeached and removed from office, paving the way for Valdas Adamkus to claim victory (Ramonaitè 2010, 74).

After the Paksas impeachment, some people felt that charges against him were not justified and that Paksas was "eliminated" by the establishment. Others believed that the removal of the compromised president was a sign of strength and the consolidation of Lithuania's democracy (Rodriguez, Drukteinis 2004) because despite the internal turmoil, Lithuania did not deviate from the track to pursue the EU and NATO membership. However, the fact that Paksas was influenced by the Russian mafia raised concerns for Lithuania's national security.

An ethnic Russian Viktor Uspaskich took advantage of Lithuanians' distrust with political parties after the Paksas impeachment and started the Labour Party in 2003. Uspaskich moved to Lithuania in 1987 and founded a natural gas company Efektas. Uspaskich also established trade contracts with the Russian state-owned Gazprom and thanks to these business dealing becoming one of the richest men in Lithuania. Later Uspaskich branched out his businesses into the food industry and employed thousands of people (Hloušek, Lubomir, 
Kopeček 2020, 64). In 2003, Uspaskich’s Labour Party participated in the very first election to the European Parliament obtaining 30 percent of votes and gaining five seats in the EU Parliament.

The Labour Party become one of the main political players in Lithuania's political life for years to come. In the 2004 elections to the Seimas, the Labor Party gained 39 seats, but this number was not sufficient to form a single-party government (Ramonaite 2010, 74). The Labour Party did not have a specific program and the rhetoric of the Labour Party was changing depending on the changing demands of the population, yet this party always remained against the "establishment". Anti-establishment rhetoric did not help Uspaskich to negotiate with potential coalition partners and as the result, Uspaskich had to give up his ambition to become a prime minister and had to be satisfied with the post of Minister of Finance (Hloušek, Kopeček 2020, 66). In 2006, Uspaskich was suspected of corruption in his personal dealings and politics and eventually had to resigned. It was speculated that Uspaskich had some dealing with Russian secret services and even took refuge in Russia for some time. Upon returning to Lithuania, Uspaskich faced trial and was sentenced to four years in prison, but managed to evade his sentence. Between 2008-2009, he was protected by the immunity as a member of the Parliament, and later as a member of the EU Parliament (Hloušek, Lubomir, Kopeček 2020, 67).

The real winners of the 2004 elections turned out to be the Social Democrats with Algirdas Brazauskas as their leader. The Social Democrats received only 20 seats, but formed a coalition with the New Union, the Labour Party, and the Union of Peasants and the New Democracy. After successful negotiations, Brazauskas become the prime minister and Artūras Paulauskas become the speaker of the Seimas (Jurkynas 2019, 125). 
The performance of the Homeland Union-Lithuanian Conservatives in the Parliamentary elections was quite successful as they increased the number of seats from nine in 2000 to twentyfive in 2004. Encouraged by this success, leaders of Homeland Union-Lithuanian Conservatives were considering a rainbow coalition with the Social Democrats under the condition that Uspaskich and Paksa's parties would not be part of the alliance. The negotiations were not successful, and the Homeland Union-Lithuanian Conservatives decided to stay in the opposition (Ramonaitè 2010, 75).

Despite the success of several of the new political parties, the left-leaning Social Democrats managed to form coalitions with the new populist parties and stayed in the majority. The right-leaning Homeland Union-Lithuanian Conservatives party refused to negotiate with the populist parties regarding coalition formation and stayed in the opposition. Some new political parties emerged just after Lithuania's independence, but they did not pass a threshold to be elected to the Lithuanian Seimas. However, in the second phase of the political party development, the new political parties received enough seats in the Seimas and become coalition partners with the Social Democrats.

Third Phrase: 2008 and Beyond: The period from 2000 to 2008 was marked by the rise and fall of the new political parties and charismatic leaders such as Paulauskas from New Union, president Paksas who was later impeached and Uspaskich from the Labour Party.

One might assume that the Lithuanian population would have been tired of new political parties and personalities and would be willing to come back to the traditional political parties. This assumption was just partially correct as the 2008 elections to the Seimas a well-known Lithuanian celebrity, showman, and a prankster Arūnas Valinskas founded the National Resurrection Party (NRP) (Klumpytė 2014, 478). 
Valinskas' political party was crowded with show people and the TV personalities. Unlike the other political parties, the NRP did not even pretend to appear to be serious politicians. Instead of a political program, Valinskas offered his "Ten Commandments" which consisted of the ten populist statements, for example, "have no other Motherlands, only Lithuania, bring glory to Lithuania, whatever you are; educate youth, because the paved the road for you" or promote Lithuanian values even abroad (Klumpyte 2014, 479). The NRP insisted on purifying Lithuanian politics and doing so in a funny way (Klumpyte 2014, 481). Duvold and Jurkynas suggest that the NRP was a political project meant to draw votes from the Uspaskich's Labor party and Paksa's TTP (Duvold, Jurkynas 2013, 130).

The Homeland Union, the Lithuanian Conservatives gained majority of the votes in 2008 and was leading negotiations to form a government. The NRP was quite successful gaining 16 seats and together with the Homeland Union, the Lithuanian Conservatives, and the Liberal Party formed the governing coalition. Andrius Kubilius, the leader from the Conservative Party, become the prime minister and Valinskas from the NRP become the Seimas speaker (Utyra, Samoškaitè 2008).

However, Valinskas met a similar fate as Uspaskich, Paksas and the other politicians that the NRP opposed. In 2009, Valinskas got involved in several scandals including his previous relationship with members of the mafia. These scandals cost Valinsas the Speaker's post, and the NRP split into the two fractions (Klumpyte 2014, 484). One of the fractions stayed with the government, and later joined the Liberal and Centre Union (LiCS). The other fraction of the NRP party joined the newly launched Christian Party (Duvold, Jurkynas 2013, 131).

A sudden rise and fragmentation of the NRP did not cause a major chaos in Lithuanian politics as Paksas or Uspaskich's scandals did. The Homeland Union-Lithuanian Conservatives 
had majority in the Seimas, and the government remained stable. However, the Kubilius government had to impose severe austerity measures which sapped the government's popularity and chances for reelection.

The financial crisis and austerity programs created a good environment for the "birth" of the new populist and conspiracy party, the Way of Courage (Drasos Kelias). The Way of Courage was created in 2012 and in the same year participated in elections to the Seimas. The Way of Courage was based on an alleged story of pedophilia that started in 2009 when the Lithuanian mass media started to podcast film materials offered by the main hero of this story Drasius Kedys, and after his death, his sister Neringa Venckiene. The Way of Courage was a single-issue party without a clear plan or programs except proposing legal system reform, but no conceptual proposals (Mažylis, Unikaitė-Jakuntavičienė, Ivanovas 2013, 69-80).

The Way of Courage was not as successful as other populist parties in the past and gained only seven seats in the Lithuanian Seimas. In the following year Venckiene, a founder of the Way of Courage, faced some legal problems herself and after losing parliamentary immunity fled to the United States (BNS, 2013).

Although, the alleged pedophilia scandal disturbed Lithuania's political system and divided society, it did not drastically change the election results. As predicted, the Homeland Union-Lithuanian Conservatives did not win the majority in the Seimas, but they showed better than expected results and were only couple of the mandates behind the Social Democrats. The same cannot be said about Liberal Party (LiSC) and the National Resurrection Party (NRP) that were in coalition with LC-HU. LiSC and NRP did not cross a 5\% threshold and did not win any seats to the Lithuanian Parliament (Jamstrinskis 2014, 38). 
In the end of the negotiations, the Social democrats who received 38 out of 141 seats in Lithuanian government formed a left-of-center coalition with the Labour Party founded by Uspaskich, Party Order and Justice founded by impeached former president Paksas and the Electoral Action of Poles in Lithuania (LLRA) (Jurkynas 2012, 335).

The reviewed literature on Lithuanian political parties reveals a contentious political climate and a lack of party consolidation. Before each election to the Seimas a new, populist, and anti-establishment political party emerged, and gained a substantial number of seats in the Seimas. The LDP emerged after the unpopular sale of Mažeikių Nafta, the NRP emerged as another political party without a clear program to divert votes from other populist parties led by Paksas and Uspaskich, and the Way of Courage was based on alleged story of pedophilia.

Lithuania's political arena is full of different parties that emerge before each election to the Seimas, but once elected to the Seimas all of these parties unite under the two-party blocks: the left-leaning and the right-leaning. This right-left divide remained true during all three phrases of the political party development in Lithuania. During the third phrase of political party development, the right-leaning Homeland Union-Lithuanian Conservatives formed the coalition with the populist NRP party. In the previous phases, the Homeland Union-Lithuanian Conservatives were reluctant to form coalitions with the newly emerged populist parties. However, the NRP did not have relations with Russia as Paksas' TPP and Uspaskich's Labour Party did. This observation suggests that in contrast to the Social Democrats, the Homeland Union-Lithuanian Conservatives do not form coalitions with parties that have connections with Russia. However, these two different (the right and the left leaning) political party blocks pursue the same energy related policies once they are elected to the Seimas. 
Table 1. "Lithuanian Party Groupings 1992-2016" below displays the right-left coalitions in the Lithuanian Seimas and the main coalition partners:

\begin{tabular}{|l|l|}
\hline \multicolumn{2}{|c|}{ Table 1. Lithuanian Party Groupings 1992-2016 } \\
\hline \multicolumn{1}{|c|}{ Right-Leaning Coalition Partners: } & \multicolumn{1}{c|}{ Left-Leaning Coalition Partners } \\
\hline $\begin{array}{l}\text { Homeland Union-Lithuanian } \\
\text { Conservatives (The Conservatives) }\end{array}$ & $\begin{array}{l}\text { The Democratic Labor Party (LDDP) - Changed } \\
\text { name to Social Democrats (LSDP) in 2000. }\end{array}$ \\
\hline Liberal and Centre Union (LiCS) & $\begin{array}{l}\text { The Liberal Democratic Party (LDP) - Changed } \\
\text { name to Order and Justice (TT) in 2006. }\end{array}$ \\
\hline National Resurrection Party (NRP) & The New Union \\
\hline Center Union & The Labour Party \\
\hline Christian Democrats & The Russian Union \\
\hline & The New Democracy \\
\hline & The Union of Peasants \\
\hline
\end{tabular}

Most of the literature I discussed in this section focused on political parties and their formations, but do not discuss laws that these parties passed or advocated for when in the Seimas. However, the literature on political parties suggests that once right leaning, left leaning, and the populist political parties are elected to the Seimas, they support Lithuania's integration to the EU and NATO and recognize energy security as a top priority to ensure national security.

In the following section, I investigate laws passes in the Seimas from 1992 to 2016. I aim to fill the gaps in the reviewed literature and find whether Lithuania's main objectives: ensure energy security and join the EU and NATO are reflected in the passed laws. I am also interested to see if the number and nature of laws passed by left leaning Seimas differ from the laws passed by right leaning Seimas. 


\section{Laws Passed on Energy Policy in the Lithuanian Seimas}

In this section, I investigate the laws that were passed in Lithuania's Seimas sessions from 1992 till the end of 2016 session. In my investigation, I ran a search in the Lithuanian Seimas website for the energy related laws. For the nuclear energy I used key words atomine elektrine (nuclear power plant), branduoline energija (nuclear energy), Ignalinos atominé elektrinè (Ignalina's Nuclear Power Plant), and Visagino atominè elektrinè (Visagino nuclear energy). For coal, I used anglis (coal) and anglies energija (coal energy) for wind energy - vejo energija (wind energy), and for solar energy-saulès energija (sun energy). I also ran a search for hydraulic fracturing using term skalūnu dujos (shale gas), hydraulinis skaldymas (hydraulic fracturing) and hydraulinis ardymas (hydraulic dismantling). In general, I found and classified 250 energy related laws, and 183 of these laws (78.2\%) were dedicated to the nuclear energy.

In this analysis, I want to see how many energy related laws were passed during each Seimas session and whether incremental changes or punctuations could be observed in the Lithuanian Seimas. I am interested in determining if more energy related laws were passed when the right-leaning government had a majority in the Seimas versus the left-leaning Seimas sessions (the Social Democrats usually made coalitions with the new populist parties). The left political parties are perceived to be friendlier to Russia, while the right-leaning political parties of Lithuania advocated for the national security and for energy security since Lithuania's independence.

Before starting my analysis, I expected the left leaning Seimas (controlled by the Social Democrats) to pass laws that would promote renewable energy and regulate fossil fuels. I also expected to find the right leaning Seimas (controlled by the Conservatives) to support fossil fuels and the nuclear energy that would ensure Lithuania's energy and national security. 
I plot my findings into the graph classified by Seimas sessions. My findings are presented in Figure 6. "Energy Policy Dynamics in the Lithuanian Seimas from 1992-2016”. In general, new members of the Lithuanian Seimas are elected every four years and their tenure lasts for four years, except for the 1990-1992 Seimas when an early election was called.

Like Baumgartner and Jones, my initial intention was to classify laws by whether they were positive, negative, and neutral towards an energy source, but all of these laws were written in neutral language, and a positive or negative tone was hard to identify. Therefore, I focus on the number of these laws and the context the energy sources were mentioned.

Lithuania regained its independence from the Soviet Union in 1990 and was formally recognized by the international community in 1991, hence the Seimas of 1990-1992 was busy with building and restating Lithuania's institutions and trying to stabilize its economic situation (lrs.lt datos 1990), so my analysis starts at 1992.

Figure 6. reveals that laws passed in the Lithuanian Seimas overwhelmingly focused on nuclear power, specifically on the Ignalina's nuclear power plant, its maintenance and later decommissioning. Lithuania had to decommission Ignalina's nuclear power plant to comply with EU requirements for membership. As the reviewed literature and laws passed in the Seimas suggest, nuclear energy was the top priority for all the Lithuanian parties in the Seimas as an object of the energy security and national security. However, all of the political parties in the Seimas also agreed that Ignalina's nuclear power plant had to be closed.

From all the laws I collected, I focused on the laws that directly addressed issues related to the energy source in question, or issues directly relating to energy policy decisions. For example, regarding nuclear power I examine laws concerning specific nuclear power plants or regulations concerning management of radioactive materials and focused less on laws that only 
mention nuclear power in passing as part of a comprehensive list. However, my study was not limited to laws about energy production and safety regulations. Because this study evaluated all mentions of the selected energy types, it included laws across a diverse range of policy areas. For example, the closure of the Ignalina nuclear power plant caused employees who worked in this power plant to lose their jobs. Because laws passed concerning assistance for these workers was a direct result of energy policy decisions, I included these labor and public assistance laws in my analysis.

\section{Figure 6. Energy Policy Dynamics in the Lithuanian Seimas}

Subject of Energy Laws Passed per Session: Lithuanian Seimas (Parliament)

60

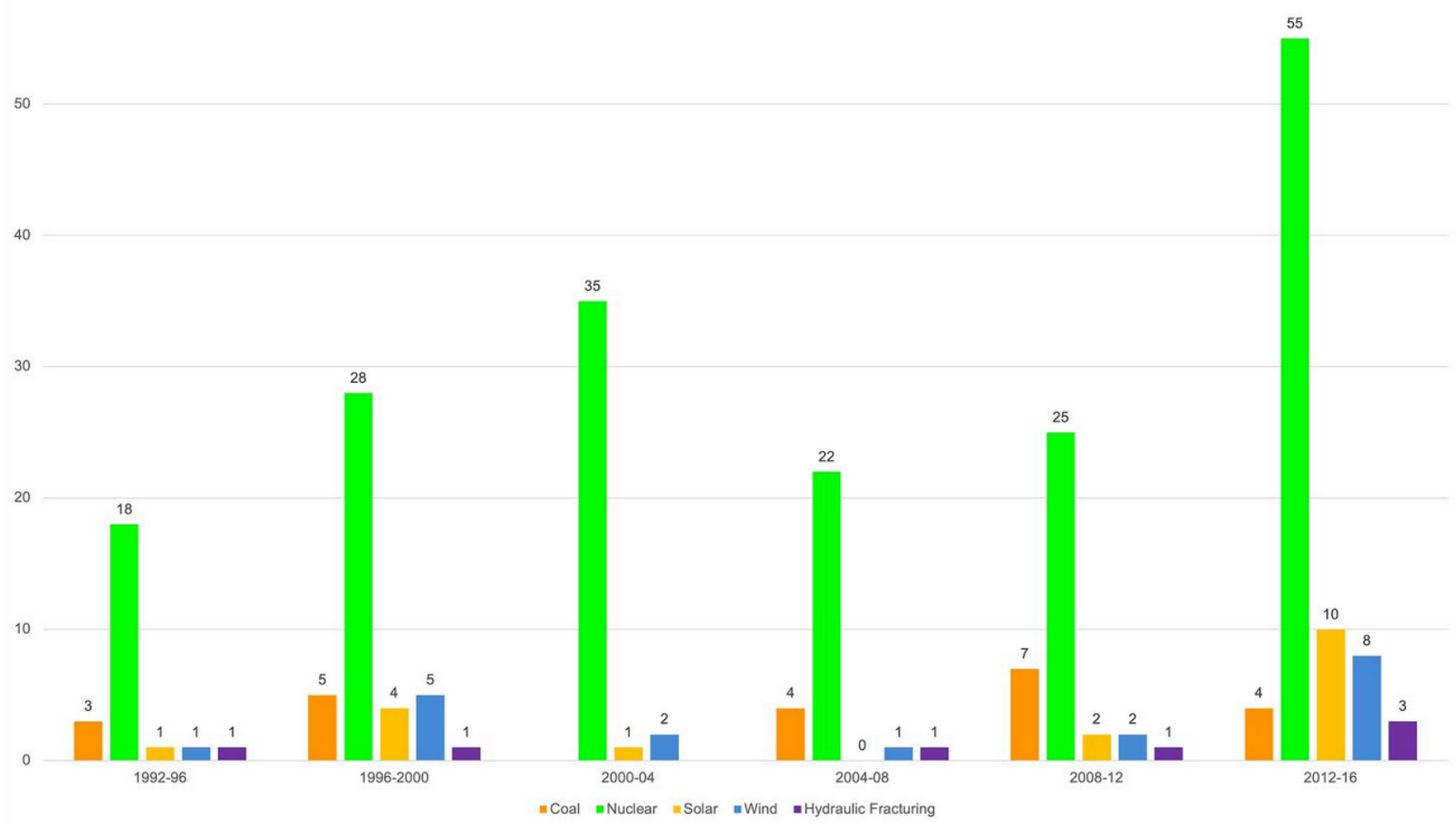

Left-leaning Seimas of 1992-1996: From 1992 to 1996, the left leaning Lithuanian

Seimas passed eighteen laws that mentioned nuclear energy, three that focused on coal energy, and one each for wind, solar, and the shale gas. I expected the left leaning Seimas to focus more 
on green energy and less on the conventional energy sources such as Ignalina's nuclear power plant. Most of the attention was dedicated to nuclear energy and Ignalina's nuclear power plant (nuclear energy was mentioned in 18 laws), but most of these mentions stressed that Ignalina's nuclear power plant as an object of significant importance. For example, law I-802 issued by the Lithuanian Seimas in 1995 referred to Ignalina's nuclear power plant as one of the multiple objects that should not be privatized (I-802, 1995). A similar law on privatization passed in 1996 stressed that nuclear energy, radioactive materials, and all the equipment related to nuclear energy should be controlled by the state institutions (I-1324, 1996).

During the 1992-1996 period, coal and other energy sources were mentioned in a similar context. The law I-774 stated that coal, gas, wood, and radioactive fuel should not have tax exemptions (I-774 1995). The Energy law signed in 1995 defined and described different energy sources, for example, this law stated that coal, shale gas, peat, biomass, flammable gases, nuclear energy, hydro energy, geothermal energy, wind, and solar should be classified as primary energy sources. Primary energy sources are those that can be used directly for fuel while secondary energy sources are extracted during the technical process. Hydropower, wood, and biomass were classified as secondary energy sources (I-828, 1995). Solar, wind, and shale gas energy were mentioned only once from 1992-1996, and only in the context in defining different energy sources.

The 1992-1996 Seimas defined primary and secondary energy sources without mentioning which energy sources are the important for Lithuania's future and energy security. 1992-1996 marks early stages of independent Lithuania's development, and the very first energy laws focused on simple identification and definitions of possible energy sources. 
Right Leaning Seimas 1996-2000: After the election of 1996, the right-leaning political party Homeland Union-Lithuanian Conservatives won the majority with left-leaning Democratic Labor Party of Lithuania (LDDP) staying in the opposition. The Seimas of 1996-2000 passed more laws on energy: 28 laws mentioned nuclear energy, five - coal, four - solar and five - wind. In comparison to the laws passed by the previous Seimas, these energy laws were more specific.

Law VIII-1443 of 1999 identifies Ignalina's nuclear power plant as a strategic object, and that information about the organization of the protection of the Ignalina's nuclear power plant should be kept as a national secret (VIII-1443, 1999). A section of the law VIII-971 of 1998 was about the prevention of nuclear accidents. This law provided a plan of action that should be followed in case of a nuclear catastrophe (VIII-971 of 1998).

Laws VIII-1661 and VIII-1747 on Ignalina nuclear power plant decommissioning focused on decommissioning Ignalinas' first reactor. This law states that Ignalina nuclear power plant was built to solve the energy problems for many countries in the Eastern Europe, and the closure of this power plant was not only Lithuania's but an international problem. Therefore, this law focused on the National Energy Strategy. This law details the financing of decommissioning programs, radioactive waste management, and social guarantees for laid off workers (VIII-1661, 2000).

Coal energy was not discussed as an important or strategic energy source, for example, the Public Procurement law VIII-1210 lists coal as a type of fossil fuel that should be regulated by the state (VIII-1210, 1999). In other cases, coal was mentioned only when clarifying terms of the primary energy source. Solar, wind, and shale gas were also mentioned in the terms of clarifying contexts; however, in general the number of the energy related laws that were passed 
from 1996 to 2000 were more specific and stressed safety and importance of Ignalina's nuclear power plant.

In 1999, Lithuania formally started accession negotiations with the European Union, and the safety of Ignalina's power plant came up during these negotiations. Therefore, Ignalina's nuclear power plant received more attention from the legislators.

More energy related laws, especially laws concerning nuclear energy, were passed during the right leaning Seimas. This increase can be attributed to Lithuania's preparation to join the EU and decommissioning Ignalina's nuclear power plant. Although right-leaning parties are perceived to focus on national security, the Seimas controlled by the Conservative parties issued laws dedicated to the decommissioning of Ignalina's nuclear power plant in order to comply with EU regulations.

Left-Leaning Seimas of 2000-2004: The Seimas session of 2000-2004 was composed of several new parties: The New Union and the Liberal Democratic Party. A coalition among the Liberal Democratic Union and the New Union lasted only a year and was changed by the coalition of the Social Democrats. However, this change in the party dynamics did not cause major change in the energy laws that were passed from 2000 till 2004.

Nuclear energy was mentioned in 35 laws, while other energy types almost did not receive attention. Most of the laws focused on the nuclear energy plant in Ignalina and its closure. Law on the State Enterprise Ignalina Nuclear Power Plant decommissioning fund approved decommissioning funds for the nuclear power plant and stated that these funds should be dedicated to address technical and social needs that might emerge. These funds also could be used to compensate for nuclear damage (IX-466, 2001). Several years later, law IX-2550 of 2004 
approved estimates of funds dedicated to decommissioning the Ignalina nuclear power (IX-2550 of 2004).

The law passed in 2001 provided some guidelines for the repairing or constructing a new nuclear power plant. This law states that a permit for the construction of a new or reconstruction of an old nuclear power plant should be issued by the Government or an institution authorized by the Government. This law also provided detailed information on documentation and licensing regarding future nuclear power plants that might be built in Lithuania (IX-586, 2001).

The Law on the Protection of Objects Important for Ensuring National Security lists Ignalina's Nuclear Power Plant as one of the main objects that have strategic importance for Lithuania's national security (IX-1132, 2002). A similar law on Lithuania's security, stated that a physical security system was being designed to protect the nuclear power plant from possible threats such as acts of terrorism (IX-1417, 2003). A similar law on national security was also dedicated to the safety of the nuclear power plant. This law also states that Lithuania together with other state institutions is responsible for organizing exercises in the event of nuclear accidents (2004, IX-2505).

Other energy sources of my interest did not receive much attention. Like the laws of previous years, solar, and wind energy were mentioned in the Energy law as type of renewable energy sources (IX-884, 2002). However, the wind farms were mentioned in the Amended Law on the Protected Areas. This law stated that it was forbidden to construct wind farms (and other pollutes) in the natural reserves (IX-628, 2001).

Although the Seimas of 2000-2004 was composed of populists, and left-leaning parties, more energy related laws were passed, and again most of them focused on decommissioning Ignalina's nuclear power plant and possibly building a new one. 
Left Leaning Seimas of 2004-2008: The Social Democrats with the populist Labour Party and other left-leaning political parties formed a governing coalition in the Seimas from 2004 till 2008. Most of the energy related laws in this Seimas were again dedicated to nuclear energy and Ignalina's nuclear energy power plant. Other energy sources did not receive a lot of attention during these four years.

Coal and the coal energy were mentioned only four times: the law of 2005 mentioned coal energy as a type of energy whose environmental impact should be evaluated. Shale gas was also mentioned as a type of fossil fuel with potential negative environmental impacts that should be evaluated $(\mathrm{X}-258,2005)$. In the other laws, coal was mentioned in the laws that were not related with energy; for example, in 2005 coal was mentioned in the procurement context (X$471,2005)$, and in the other two laws coal was mentioned in terms of the danger posed by carbon dioxide.

The law of 2005 was dedicated to the decommissioning of the first reactor of the Ignalina's nuclear power plant. This law detailed the final decommissioning plan, preparatory work plans, stages, and the decommissioning projects of the facilities (X-202, 2005).

A law passed in the same year detailed the unemployment benefits that the laid off workers should receive after closing of the first Ignalina's power plant reactor $(X-254,2005)$. The law of the 2006 addressed issues related to Ignalina's nuclear power plant decommissioning funds and funds for the management of radioactive waste (X-741, 2006).

Solar energy from 2004 to 2008 was not mentioned in any laws at all, and the wind farms were mentioned only in the amended law on the Environmental Impact Assessment of Proposed Economic Activities. This law regulates installation of wind turbines when their height, including wing length, is more than 10 meters (X-258, 2005). 


\section{Right Leaning Seimas of 2008-2012: The New National Resurrection Party (NRP)}

made a successful entry into the Lithuanian Seimas in 2008, but it was the Homeland UnionLithuanian Conservatives that formed a right-leaning coalition. Although, the right leaning political parties and governments are believed to emphasize and focus on the national security and energy security, the number of laws regarding energy from 2008 till 2012 decreased.

The number of laws that mention coal increased but did not portray coal in a positive light. The law on Climate Change and Management states that Lithuania should decrease CO2 emission and combat the greenhouse effect (XI-329, 2009). The other citing of coal energy was rather neutral but also mentioned in the laws related with climate change and in the Renewable Energy Laws.

Solar and wind energy received a bit more attention: The law on Territorial Planning stated that the wind farms should not be constructed in rural areas and towns close to the buildings (XI-619, 2009), and the law on Renewable Energy provided more details on constructing solar power plants and wind farms. This law stated that construction sites of wind farms in territories that were important to Lithuania's national security should be coordinated with the Lithuanian Armed Forces. The noise level of a wind power plant in adjacent residential plots must comply with the noise limit values set by the Minister of Health (XI-1375, 2011). The Law of Renewable Energy suggests that wind and solar energy was becoming more popular in Lithuania and comprehensive laws regulating renewable energy were needed.

From 2008 till 2012 most legislative attention was focused on nuclear energy and national security. One of these laws stated that to ensure Lithuania's energy independence, competitiveness, sustainable development and the future economic growth, Lithuania should remain a nuclear country. According to this law, the new nuclear power plant would ensure 
Lithuania's constitutional values such as the general well-being of the nation, the capacity and competitiveness of the country's economy, freedom and initiative of economic activity, and environmental protection (XI-2084, 2012).

The next law on energy addressed a possible connection of Lithuania's electricity system to the electricity networks in the continental Europe for the synchronous operation. In 2012, it was still a hope that the new nuclear power plant would be built and integrated into the continental European electricity networks (XI-2052, 2012). However, a referendum that was held in the fall of 2012 shattered hopes of the new nuclear power plant when more than 60 percent voters voted against the construction of new nuclear power plant in Lithuania (Lietuvos Respublikos Seimo rinkimai ir referendumas...).

Left-Leaning Seimas of 2012-2016: Elections for the Seimas in 2012 granted a majority to the Social Democrats which formed a coalition with left leaning political parties. After the unexpected results of the 2012 referendum, it was clear that construction of the new nuclear power plant in Lithuania was not going to happen. However, the laws that mentioned nuclear energy had skyrocket between 2012 and 2016, and most of these laws were dedicated to the decommissioning of the nuclear power plant and implementing the provisions of the law on additional employment and social guarantees for Ignalina's nuclear power plant employees (XII737, 2013). Likewise, the law of 2016 details the conditions under which severance pay and additional severance would be paid to former Ignalina's nuclear power plant employees (XII2504, 2016).

In the other laws, nuclear energy was mentioned as a primary energy source in the amended laws or in the context of improving energy efficiency (XII-2702, 2016). Several laws 
mentioned nuclear energy in the context of radiation safety and physical safety of ionizing radiation sources (XII-2190, 2015).

In this Seimas session, coal energy was mentioned four time, for example, the law of Excise Duties exempted coal, coke and lignite from the excise duty (XII-2128, 2015). The other law was dedicated to the climate change and this law stated that the amount of carbon dioxide emitted into the atmosphere should not exceed the amount of carbon dioxide emitted in the during the previous calendar year (XII-1483, 2014).

More laws were passed addressing wind and solar energy sources: solar energy was mentioned ten times, and wind energy - eight times during the 2012-2016 Seimas. The law of Renewable Energy allowed for an increase in the total installed capacity of solar power plants connected to the electricity grid to $10 \mathrm{MW}$, excluding small power plants with an installed capacity not exceeding $30 \mathrm{~kW}$. The same law also states that the Government should prepare and approve a description of the procedure for further development of solar power plants that considers the obligations to reduce environmental pollution and to ensuring security and reliability of energy supply (XII-169, 2013). The other energy related laws (XII-170, XII-1389, XII-1666) referring to the solar energy are similar, most of them were issued to regulate the construction of solar light power plants (XII-170, 2013, XII-1389 2014, XII-1666 2015).

The laws referring to the wind farms were like the ones discussing solar light power plants. And in several cases, wind and solar energy were mentioned in the same laws as a type of renewable energy. For example, the law of 2015 stated that permits to develop wind farms and solar light power plants in the Curonian Spit (Curonian Spit is a UNESCO World Heritage Site) and in the exclusive economic zone of the Republic of Lithuania should be issued by the government or by its authorized institutions (XII-1666, 2015). 
The other laws on the renewable energy reiterated similar restrictions and regulations issued in the previous laws. These laws addressed permitting process that was needed to start constructing wind farms in the territories that were significant to Lithuania's national security (XII-847, 2014).

Hydraulic fracturing was mentioned three times in the laws that were passed between 2012-2016. Hydraulic fracturing resulted a lot of debates in Lithuania and in the EU countries where shale gas was discovered. Between April 4 and December 31, 2013, hydraulic fracturing was mentioned 96 times in the national newspaper Lietuvos Rytas and in the regional newspaper Taurages Kurjeris (Taurges Kurjeris is a newspaper in the region of Lithuania where the shale gas was discovered). From January 1 to July 12, 2014 shale gas was mentioned 32 times in Lietuvos Rytas and Taurages Kurjeris, mostly in a negative light. Public dissatisfaction with hydraulic fracturing resulted in the American company Chevron's decision to withdraw from its plans to explore the shale gas reserves in Lithuania. Chevron blamed "significant changes to the fiscal, legislative and regulatory climate in Lithuania. Chevron claimed that these changes impacted the operational and commercial basis of the investment decision since the company submitted its bid in January 2013" (Sytas, 2013).

The main law on hydraulic fracturing was passed in 2013, and the section of the law that most likely discouraged Chevron from future shale gas exploration stated that use of radioactive, toxic or dangerous substances that are needed for subsoil exploration must be disclosed: "the persons holding a subsoil exploration permit issued by the Government or its authorized body must provide the competent authority with a complete list of radioactive, toxic or hazardous substances for the human health or the environment..." (translation from the law XII-352, 2013). The other law that was passed in 2013 clarified the definition of hydraulic fracturing in one 
sentence (XII-353, 2013). The later law on hydraulic fracturing prohibited exploration and /or use of dispersed hydrocarbons by hydraulic fracturing in protected areas, groundwater protection zones and drinking water treatment plant areas (XII-1786, 2015). Most of the laws were written in the neutral language, but laws on hydraulic fracturing were negative and restrictive towards shale gas exploration.

Although the Seimas of 2012-2016 was controlled by the left-leaning political parties, the number of energy related laws had increased substantially in comparison with the previous years. Most of the laws were dedicated to the nuclear power plant and its decommissioning.

More laws were dedicated to the solar and wind energies. It is possible that decommissioning of the Ignalina's nuclear power plant encouraged Lithuania to look for the alternative energy sources. Hydraulic fracturing appeared to be a controversial topic in Lithuania, and hydraulic fracturing company Chevron criticized changed laws that made hydraulic fracturing in Lithuania impossible. However, hydraulic fracturing received a lot of criticism from the public, hence it is hard to say if changed laws can be attributed to the left leaning Seimas.

\section{Conclusions}

Laws that were passed in the Seimas between 1992-2016 did not suggest a major variation in Lithuania's energy policy. These findings are a bit surprising because I expected right- and left-leaning governments to issue different types of energy related laws. I also expected to observe punctuations in these energy laws.

The left leaning Seimas of 2012-2016 passed more energy related laws and laws on nuclear energy also increased substantially in those years. However, I would not identify these changes as punctuations, but as incremental increases related to the closure of Ignalina's nuclear power plant. The right and left-leaning political parties were moving forward with closing the 
Ignalina's power plant to comply with the EU regulations, and many of these laws addressed this closure.

Presented data (see Figure 1) suggests that political parties in the Seimas do not resemble U.S. congressional behavior. In the U.S Congress, negative views on nuclear energy came to dominate congressional agenda in the mid-1970s. These negative views increased even more after the Three Mile Island accident (Baumgartner, Jones 2009, 74). However, the Lithuanian Seimas does not seem to respond to the punctuating event of the Fukushima accident in Japan in 2011. After that accident, Lithuanian policy makers were still planning to build a new nuclear power plant that would have replaced the closed one. National security and energy security were the main factors that drove Lithuania's political party behavior, as Lithuania's policy makers perceived energy and national security in the EU.

The energy blockade of 1990 and other energy related incidents proved Russia to be an unreliable partner, and as a result, Lithuania has been looking for protection to the Western organizations such as the EU and NATO. A desire to join the EU created a paradoxical situation among Lithuania's political parties because they had to sacrifice the Ignalina nuclear power plant in hopes of joining the EU and benefiting from EU energy projects. Therefore, it is possible to conclude that hostile relationship with Russia prevented punctuations in Lithuania's energy policy from occurring.

In contrast to the Lithuanian Seimas, it is most likely that the Lithuanian public reacted to the Fukushima accident because the plan to build a new nuclear power plant was defeated in the 2012 referendum. The outcome of this referendum was a bit surprising because high energy prices had always been a concern for the Lithuanian people, but it seems that majority of 
Lithuanians voted against their immediate economic self-interest to gain greater national security.

Coal and the coal energy were not prevalent in Lithuania as much as it was in the other EU countries, hence the number of laws that mentioned coal energy was minimal. However, the right leaning Seimas did not mention coal in a positive light as coal was linked to climate change. This is an interesting finding since I expected the left-leaning Seimas to emphasize climate change. It is possible to conclude that coal policy in Lithuania underwent incremental change as the number of coal and coal energy related laws remained the same over the years.

Wind and solar energy laws also changed incrementally. The first Seimas sessions did not dedicated a lot of attention to these energy source, but in the later years the number of these laws increased. This change can be attribute to EU policies that were designed to foster wind and solar energy as tools to combat climate change and address other environmental concerns. This increase also can be attributed to the decommissioning of Ignalina's nuclear power plant and the unsuccessful referendum to construct a new nuclear power plant.

Hydraulic fracturing was heavily covered and editorialized by the Lithuanian press, and subsequently the left leaning Lithuanian Seimas passed three laws that addressed environmental concerns related to fracking between 2012 and 2016. Similar to the EU Parliament, hydraulic fracturing was welcomed to Lithuania in the beginning, but the Lithuanian national and regional press did not portray hydraulic fracturing in a positive light. In addition, hydraulic fracturing received negative attention from the EU Parliament from most of the party groupings ${ }^{7}$.

Laws restricting and requiring disclosure of chemicals that are used in hydraulic fracturing were passed when left-leaning political parties had a majority in the Seimas, however,

\footnotetext{
${ }^{7}$ Please see the third chapter of this dissertation for more information, page 91.
} 
more investigation is needed to determine how much party politics alone contributed to the passing of these laws.

This analysis of Lithuania's energy laws allows me to conclude that most of the changes in the Lithuania's energy policy have been incremental. The Lithuanian Seimas did not respond to punctuating events as the U.S. Congress did after the Three Mile Island accident. An increased in attention to the Ignalina's nuclear power plant and nuclear energy in general can be attributed to the EU requirement to close the only nuclear power plant in Lithuania.

In this study I did not analyze energy related bills that were proposed by the members of Seimas, but did not become laws. I suggest that further analysis of proposed energy laws would give a better understanding of the Lithuanian political parties' attitudes towards different energy sources and decommission of Ignalina's nuclear power plant.

I suggest that PET can be applied in studying energy policy in Lithuanian Seimas. The Fukushima accident created an opportunity for the policy change in energy laws in Lithuanian Seimas, but substantial changes did not occur, Prior energy blockades and the Soviet occupation prevented significant changes in Lithuania's energy policy from happening. However, when it comes to the questions of energy security, the political party affiliation does not matter, as all major political parties in Lithuania seek for the energy security and energy independence.

I suggest that all of the major political parties in Lithuania frame energy policy as external security concern. In addition, given the short timespan the Lithuania's been independent, the period I studied is an extended equilibrium that is brought about by the Russian threat. If Lithuanian and Russian relationship will normalize in the future, Seimas might responds to punctuating events in the way the theory would predict. 


\section{Chapter 5. Conclusion and Future Research}

The principal question this dissertation explored was punctuation equilibrium theory (PET) and its applicability to the EU Parliament and the Lithuanian Seimas, measured by the quantity and tone of several sources of legislative work product: parliamentary questions and laws passed. Several political scientists have applied PET to the EU Council and in other western democracies, but not in these two institutions.

Classic punctuation equilibrium theory was first proposed by American political scientists Frank Baumgartner and Bryant Jones, who sought a theoretical explanation for sudden changes that occur in a policy area after years of relative stability. They argue that changes in the policy equilibrium can be associated with electoral changes or when a sense of urgency overwhelms the political system and forces political actors to unite (Baumgartner, Jones 2009, 21). In order to apply this principle to European energy policy, I studied how MEPs reacted to punctuating events through their questions to the EU Parliament from 1994 to 2014 and energyrelated laws passed by the Lithuanian Seimas from 1992 to 2016 . While no significant punctuating events were detected within the time frame of this study, the data do show a clear response to real world events and future research should continue to examine these two institutions using PET.

\section{Findings: Trends in Questions and Policy Attention by Energy Source}

In my examination of legislative behavior in the EU Parliament, I examined what external factors may have influenced the nature written questions that MEP submitted to the EU Commission from 1994 to 2014. Such changes in legislative behavior included the increase or decrease in the number of questions submitted concerning a particular issue or energy source, 
and changes in tone from positive to negative or vice versa. My data suggests that the Fukushima nuclear disaster caused a temporal punctuation in the EU Parliament, but this punctuation was not long-lasting and after a year the number of written questions submitted to the EU Commission returned to their prior level and substantially decreased by 2014. Nuclear energy did not enjoy a positive image before the Fukushima accident, but was tolerated by the MEPs as an alternative to coal and other fossil fuels. It is possible that nuclear power could have experienced a renaissance in favorable public opinion had the Fukushima disaster never occurred, but there is insufficient data to speculate about this and there was no obvious reversal of public sentiment, only a return to existing levels of skepticism.

The Fukushima nuclear disaster also prompted MEP to submit more questions regarding alternatives to nuclear power: coal, wind, and solar. These findings suggest that the Fukushima nuclear disaster caused MEPs to shift their attention towards renewable energy sources and to submit more questions regarding solar and wind energy. Coal related questions increased incrementally since 1994 and the content of most of these questions was negative.

The increase in written questions after Fukushima is most noticeable in wind and solar energy. With a few exceptions, the content of most of the questions concerning wind and solar power were positive. As questions about nuclear and coal energy incrementally decreased and become more negative, questions about wind and solar energy incrementally increased and the Fukushima accident prompted this increase.

The exception to this additional interest in alternatives was hydraulic fracturing, an emerging technology used to extract natural gas from previously unrecoverable shale formations. This technique as applied to unconventional shale beds was relatively new during the time frame of this study and received some positive attention from MEPs in its early stages. But perception 
of hydraulic fracturing started to change when some EU member countries banned this technique, and when negative effects of hydraulic fracturing started to emerge. After reaching its peak in 2013, questions regarding hydraulic fracturing began to decline. Although the Fukushima disaster incited MEPs to submit more energy related questions in 2011, these spikes were short lived. Within a year the questions plateaued.

\section{Findings: Questions to EU Parliament Reveal Occasional Tensions Between National Interests and International Party Groupings}

Studying the volume and content of questions to the EU Parliament also provided some new information about the behavior of political party groupings. As discussed in Chapter 3, the national interests of political party groupings rarely supersede MEPs allegiance to their European Parliament party groupings. Based on my results, I suggest that in most cases MEPs submit questions to the EU Parliament in allegiance with their European Parliament party group, but not always; occasionally, national interests overrule EU party agendas.

In general, Green political party groupings (Verts/ALE and GUE/NGL) opposed coal energy, nuclear energy, and hydraulic fracturing, but supported solar and wind energies. Centerright political party groupings such as the Christian Democrats (EPP or PPE) were more supportive of all energy sources. This support can be explained by the fact that energy security is a priority for the Christian Democrats, thus they were less likely to criticize coal and nuclear energies compared to the Greens.

Circumstances changed after the Fukushima disaster when almost all the parties expressed concerns towards nuclear energy. However, Christian Democrats from Poland supported nuclear energy, again, citing energy security. In this instance, the Polish national interest in energy security overrode the temporary consensus to criticize nuclear energy. MEPs 
from the left-leaning socialist political party grouping, the liberal party grouping, and the radicalEurosceptic party grouping were generally not supportive of nuclear energy.

There was similar overall consensus within party groupings concerning shale gas exploration using hydraulic fracturing. MEPs from the Green party groupings strongly opposed hydraulic fracturing while Christian Democrats and radical-Eurosceptic MEPs from Poland supported hydraulic fracturing citing Poland's experience with this new technology and the need for reliable energy sources due to dependency on Russia. Christian Democrats from Germany also encouraged the EU Commission to investigate hydraulic fracturing because countries that depend on Russian energy would benefit from an alternative energy source. In the case of hydraulic fracturing, MEPs remained consistent and did not deviate from their political party grouping: the Christian Democrats were interested in exploring hydraulic fracturing technology, while the Greens opposed it.

There was more deviation between party lines and national interest concerning coal. On the Left, most Green party groupings criticized coal energy (including so-called "clean coal"), but Greens from Spain were concerned about workers' rights and lost subsidies to the coal industry. Green MEPs from Scotland (UK) also departed from other MEPs in the Green party grouping and expressed support for a "clean coal" power plant.

On the right, some MEPs from the radical-Eurosceptic party grouping expressed fierce support for the coal energy while others criticized it. One Italian MEP from the radicalEurosceptic party grouping did not approve coal energy, but another Italian MEP from the same party grouping supported it. MEPs from radical-Eurosceptic party grouping from Poland and Lithuania also argued in favor of coal, emphasizing the fact that coal energy would decrease dependency on Russian energy. These findings suggest that questions submitted by MEPs from 
the radical-Eurosceptic party grouping were based on their opinion or served the interest of their member country. In this respect, MEPs from the radical-Eurosceptic party grouping behaved in a similar way to their independent colleagues who are not associated with any political party grouping and who could submit any questions they liked.

MEPs from the liberal party grouping did not submit many questions on coal energy, but the ones they submitted were mostly negative. MEPs from the Christian party grouping supported coal or at least justified its continued use. However, the Social Democrats had diverse opinions regarding coal energy. While most Social Democrat MEPs were critical of the coal industry, Social Democrats from Poland were in favor of it for national reasons.

\section{Areas for Future Study in the European Union}

To better measure the potential effect the Fukushima accident may have had on attitudes towards nuclear power and on the other energy policies in the EU Parliament, it would be beneficial to extend my study through 2020 to investigate what effect Fukushima had on subsequent questions that MEPs submitted to the EU Commission. I expect that written questions on wind and solar energy continued to increase, while questions on nuclear energy and coal energy decreased. I also expect that hydraulic fracturing continued to receive negative attention.

This study focused on the written questions that members of the European Parliament submitted to the EU Commission. To get a clearer picture of energy policy dynamics in the European Union, it would be useful to also investigate the answers that members of the European Commission provided in response to the submitted questions. I believe that the Commission's answers could provide a better understanding how it changed its policies toward nuclear, coal, wind, solar, and hydraulic fracturing policies overtime. As indicated in Chapter 2, the EU 
Commission supported a common energy policy, but usually encountered resistance from member states. Therefore, it would be interesting to investigate if support for a common energy policy is reflected in the Commissions' answers.

The European Council's conclusions are the other documents that I would like to analyze to see how much attention the it dedicated to nuclear, coal, hydraulic fracturing, wind, and solar energy. I believe that the further research would supplement this study and would give a clearer picture of energy policy dynamics in the European Union. My analysis on the written questions that MEPs submitted to the EU Commission from 1992 - 2014 supports Baumgartner and Jones statement that punctuated dynamics is a very general feature of policymaking and can be applied outside the U.S (Baumgartner, Jones 2009, 12). In my case studies on nuclear, coal, hydraulic fracturing, wind and solar energy, I observed an increase in the written questions that were caused by the Fukushima nuclear disaster, and I have also observed incremental changes in these energy policies.

\section{Energy Policy Dynamics in the Lithuanian Seimas}

In Chapter 4, I investigated whether PET is applicable to the relatively new democratic country of Lithuania. I tested PET's applications in the Lithuanian Seimas by analyzing energy laws that were passed from 1992 to 2016. My findings suggest that the hostile relationship with Russia, and its energy blockades on Lithuania most affected behavior in the Seimas.

Different political parties in the Seimas did not respond to the punctuating events such as Fukushima as the number of energy related laws remained similar over the years, and most of these laws were related with the Ignalina nuclear power plant and its decommissioning. To decommission nuclear power plant was not an easy decision because the nuclear power plant reduced Lithuania's dependency on Russian energy. 
Right and left leaning political parties in Lithuanian Seimas supported EU membership and complied with the EU pre-accession agreement to close the plant. This is not the result I have expected before starting my analysis. I expected left-leaning political parties, like the Social Democrats, would promote renewable energy sources. I also expected that right-leaning political parties, like the Homeland Union-Lithuanian Conservatives, would support Lithuania's membership in the EU, and promote nuclear, coal, gas, and any energy source that would help Lithuania to secure energy independence from Russia.

However, in terms of energy policy, all the main Lithuanian political parties behaved in a similar way. After the closure of Ignalina, the left leaning Seimas passed more energy related laws and started focusing on wind and solar energy, and as a result energy related laws started increasing.

I suggest that despite the lack of responses to a punctuating event like Fukushima, PET is useful for studying Lithuania's energy policy because it helps to uncover and explain incremental changes in the Lithuanian Seimas, and to detect some possible punctuations in the public opinion. In 2012, Lithuanian citizens voted against the proposed plan to build a new nuclear power plant in Lithuania. This surprising result suggests that most of the Lithuanian citizens were influenced by the Fukushima accident and as a result voted against the new nuclear power plant.

To supplement my study, in the future I will analyze proposed laws on energy that did not receive enough votes in Seimas to pass. I believe that this would give a better understanding on energy policy dynamics among left- and right-leaning political parties, i.e., whether they propose different energy laws. In future research, I would also be interested in analyzing Lithuanian media coverage to see how many negative articles were published on the Lithuanian 
Seimas prior to the referendum to build a new nuclear power plant. I expect that Fukushima and the proposed new nuclear power plant were covered in a negative light in the main Lithuanian newspaper, Lietuvos Rytas.

Poland and Lithuania shared a similar history and aggressions from Imperial Russia and the Soviet Union. MEPs from Poland emphasized energy security and supported conventional energy sources such as coal energy and nuclear energy. Therefore, another potential area of future research would be to test PET's potential utility in explaining behavior in Poland's Parliament - Sejm. 


\section{Bibliography}

Alexandrova, P., \& Timmermans, A. (2013). National Interest versus the Common Good: The Presidency in European Council agenda setting. European Journal of Political Research, 52(3), 316-338.

Alexandrova, P. (2015). Upsetting the agenda: the clout of external focusing events in the European Council. Journal of Public Policy, 35(3), 505-530.

Alexandrova, P., Carammia, M., \& Timmermans, A. (2012). Policy punctuations and issue diversity on the European Council agenda. Policy Studies Journal, 40(1), 69-88.

Alexandrova, P., Rasmussen, A., \& Toshkov, D. (2016). Agenda responsiveness in the European Council: Public priorities, policy problems and political attention. West European Politics, 39(4), 605-627.

A New Economic Model for a Progressive Europe, S\&D. Retrieved June 29, 2021, from https://www.socialistsanddemocrats.eu/what-we-stand-for/our-priorities

A Sustainable Europe, EPP. Retrieved June 28, 2021 from

https://www.epp.eu/commitments

A Secure and Free Europe, EPP. Retreived June 25, 2021 from

https://www.epp.eu/commitments

Balmaceda, M. M. (2018). Politics of Energy Dependency. University of Toronto Press. Hopkins Press.

Battaglia, F.(1957). European Integration. Edited by Haines, Charles Grove. Johns

Baumgartner, F. R., \& Jones, B. D. (2010). Agendas and Instability in American politics. University of Chicago Press.

Baumgartner, F. R. (2006). Punctuated equilibrium theory and environmental policy. In Punctuated equilibrium and the dynamics of US environmental policy (pp. 24-46). Yale University Press.

Baumgartner, F. R., Foucault, M., \& François, A. (2006). Punctuated equilibrium in French budgeting processes. Journal of European Public Policy, 13(7), 1086-1103.

Baumgartner, F. R., Breunig, C., \& Grossman, E. (Eds.). (2019). Comparative policy agendas: Theory, tools, data. Oxford University Press.

Radio Free Europe - Radio Liberty. Belarus Launches Nuclear Power Plant Despite 'Safety Issues'. (2020, November 3). https://www.rferl.org/a/belarus-launched-nuclear-powerplant-despite-safety-issues-/30928660.html 
Belchior, A. M., \& Borghetto, E. (2019). The Portuguese Policy Agendas Project. Comparative Policy Agendas: Theory, Tools, Data. Oxford: Oxford University Press (145-151).

Birkland, T. A. (1998). Focusing events, mobilization, and agenda setting. Journal of public policy, 18(1), 53-74.

Birkenmeier, B., Carson, P. P., \& Carson, K. D. (2003). The Father of Europe: An analysis of the supranational servant leadership of Jean Monnet. International Journal of Organization Theory \& Behavior.

BNS/TBT Staff. (2021, May 12). Lithuania runs nuclear emergency alert drill. The Baltic Times. https://www.baltictimes.com/lithuania_runs_nuclear_emergency_alert_drill/

Boda, Z., \& Sebők, M. (2019). The Hungarian Agendas Project. Comparative policy agendas: Theory, tools, data.

Borghetto, E., Carammia, M., \& Russo, F. (2019). The Italian Agendas Project. In Comparative Policy Agendas (pp. 120-128). Oxford University Press.

Brack, N. (2013). Euroscepticism at the Supranational Level: The case of the 'untidy right' in the European Parliament. JCMS: Journal of Common Market Studies, 51(1), 85-104.

Brack, N., \& Costa, O. (2019). Parliamentary Questions and Representation of Territorial Interests in the EP. In The European Parliament in Times of EU Crisis (pp. 225-254). Palgrave Macmillan, Cham.

Bulut, A. T., \& Yildirim, T. M. (2019). The Turkish Policy Agendas Project. Comparative Policy Agendas: Theory, Tools, Data, 167-175.

Cairney, P. (2011) Understanding Public Policy: Theories and issues. Macmillan International Higher Education.

Cairney, P., Studlar, D. T., \& Hadii, M. M. (2013). Understanding Public Policy: Theories and issues. Public Administration, 91(3), 782-793.

Carammia, M., Princen, S., \& Timmermans, A. (2016). From Summitry to EU Government: An agenda formation perspective on the European Council. JCMS: Journal of Common Market Studies, 54(4), 809-825.

Chang, Y., Fang, Z., \& Li, Y. (2016). Renewable energy policies in promoting financing and investment among the East Asia Summit countries: Quantitative assessment and policy implications. Energy Policy, 95, 427-436.

Chaqués-Bonafont, L., Palau, A. M., \& Marquez, L. M. (2019). Agenda Dynamics in Spain. Comparative Policy Agendas: Theory, Tools, Data. 
Clark, T. D. (1994). The Lithuanian Political Party System: A case study of democratic consolidation. East European Politics and Societies, 9(1), 41-62.

Clark, T. D., Verseckaitè, E., \& Lukošaitis, A. (2006). The role of committee systems in post-communist legislatures: A case study of the Lithuanian Seimas. Europe-Asia Studies, 58(5), 731-750.

Clarke, Thomas H., Pappas, Dean A. 2012. "Under Cover: Do homeowners policies protect against liability from fracking operations?” Best's Review 112 (10): 61-63.

About: Council of the European Union, European Union. Retreived June 25, 2021 from https://europa.eu/european-union/about-eu/institutions-bodies/council-eu_en

Corbett, R., Jacobs, F., \& Shackleton, M. (2011). European parliament. ProQuest Ebook Central. https://ebookcentral.proquest.com

Coyle, E. D., \& Simmons, R. A. (2014). Understanding the Global Energy Crisis. Purdue University Press.

Chronology: Major mining disasters < https://www.dw.com/en/chronology-majormining-disasters/a-17637498 $>$ Accessed in July $18^{\text {th }}, 2021$.

Dahlburg, J.T.,E. Schrader. (1990, April 18). Blockade Is On, Lithuania Says: Secession: Gorbachev is accused of 'brutal' action on natural gas and oil. But Moscow denies any cutbacks. Los Angeles Times. https://www.latimes.com/archives/la-xpm-1990-04-18-mn-1271story.html

Delsoldato, G. (2002). Eastward enlargement by the European Union and transnational parties. International Political Science Review, 23(3), 269-289.

Deutch, J. M. (2011). The Crisis in Energy Policy. Harvard University Press.

Digrytė. E. (2006, April 11). A.Paulauskas atstatydintas iš pareigų. Delfi News. https://www.delfi.lt/news/daily/lithuania/apaulauskas-atstatydintas-is-pareigu.d?id=9286748

Duvold, K., \& Jurkynas, M. (2013). 6. Lithuania. The Handbook of Political Change in Eastern Europe, 125.

Dowding, Keith, Aaron Martin, and Rhonda L. Evans. "The Australian Policy Agendas Project" Comparative Policy Agendas: Theory, Tools, Data. : Oxford University Press March 21, 2019. Oxford Scholarship Online

Eberlein, B. (2012). Inching Towards a Common Energy Policy: Entrepreneurship, incrementalism, and windows of opportunity. Constructing a policy-making state, 147-69. 
European Conservatives and Reformists. Protecting the Global Environment at a Cost we can Afford. Retrieved May 27, 2021 from

https://ecrgroup.eu/vision/protecting_the_global_environment_at_a_cost_we_can_afford

European Union. About: European Parliament. https://europa.eu/european-union/abouteu/institutions-bodies/european-parliament_en

Evans, Rhonda L. (2019, March 21) "The New Zealand Policy Agendas Project." Comparative Policy Agendas: Theory, Tools, Data. Oxford University Press.

Ferrara, F., \& Herron, E. S. (2005). Going it Alone? Strategic entry under mixed electoral rules. American Journal of Political Science, 49(1), 16-31.

Frack to the Future. (2013, February 2). The Economist. https://www.economist.com/business/2013/02/02/frack-to-the-future

Fukushima Daiichi Accident (Updated May 2020). World Nuclear Association. Retreived May 5, 2021 from https://www.world-nuclear.org/information-library/safety-andsecurity/safety-of-plants/fukushima-daiichi-accident.aspx

Gauvin, Jean-Philippe, and Éric Montpetit. (2019, March 21). "The Canadian Agendas Project." Comparative Policy Agendas: Theory, Tools, Data. Oxford University Press.

Gava, Roy, Pascal Sciarini, Anke Tresch, and Frédéric Varone. (2019, March 21). "The Swiss Policy Agendas Project." Comparative Policy Agendas: Theory, Tools, Data. Oxford University Press.

Glockner, I., \& Rittberger, B. (2012). The European Coal and Steel Community (ECSC) and European Defence Community (EDC) Treaties. In Designing the European Union (pp. 1647). Palgrave Macmillan, London.

Goldthau, A., \& Witte, J. M. (2010). Global Energy Governance: The new rules of the game Brookings Institution Press. Washington, DC.

Gore, A. (2006). An Inconvenient Truth: The planetary emergency of global warming and what we can do about it. Rodale.

Grigas, A. (2016). The Politics of Energy and Memory between the Baltic States and Russia. Taylor and Francis.

Grigoravičiūtè, A. (2014). Lithuanian Constitutional Court: The eligibility ban for those removed under impeachment procedure. ICL Journal, 8(1), 112-117.

Green-Pedersen, Christoffer, and Peter B. Mortensen. (2019, March 21). "The Danish Agendas Project." Comparative Policy Agendas: Theory, Tools, Data. Oxford University Press. 
Greens/EFA. Our Vision. Retrived May 25, 2021 from https://www.greensefa.eu/en/what-we-stand-for/our-vision.

Grossman, Emiliano. (2019, March 21). "The French Agendas Project." Comparative Policy Agendas: Theory, Tools, Data. Oxford University Press.

Hix, S., and Hoyland. (2011). The Political System of the European Union. 3rd ed./ ed., Palgrave Macmillan,

Hix, S., Noury, A., \& Roland, G. (2009). Voting patterns and alliance formation in the European Parliament. Philosophical Transactions of the Royal Society B: Biological Sciences, 364(1518), 821-831.

Hix, S., \& Noury, A. (2009). After Enlargement: Voting patterns in the sixth European Parliament. Legislative Studies Quarterly, 34(2), 159-174.

Hix, S., Raunio, T., \& Scully, R. (2003). Fifty Years On: Research on the European Parliament. JCMS: Journal of Common Market Studies, 41(2), 191-202.

Hix, S. (1999). The Political System of the European Union. Macmillan International Higher Education.

Hix, S., \& Marsh, M. (2011). Second-order effects plus pan-European political swings: An analysis of European Parliament elections across time. Electoral Studies, 30(1), 4-15.

Hloušek, V., Kopeček, L., \& Vodová, P. (2020). The rise of entrepreneurial parties in European politics. Springer Nature.

Hooghe, L. (2002). The European commission and the integration of Europe: Images of governance. ProQuest Ebook Central https://ebookcentral.proquest.com

Hönig, V., Prochazka, P., Obergruber, M., Smutka, L., \& Kučerová, V. (2019). Economic and technological analysis of commercial LNG production in the EU. Energies, 12(8), 1565.

Hughes, L., \& Lipscy, P. Y. (2013). The Politics of Energy. Annual Review of Political Science, 16, 449-469.

Imse, A.(1990, April 17). Moscow to Start Shutting Off Gas Supply to Lithuania. AP. https://apnews.com/article/bcef2583ed6639c47725560762caled3

Istrate, L. (2012). The Baltic States Between The Old And New Europe. The Benefits Of Lisbon Treaty For Lithuania, Latvia And Estonia. Revista Româna Geografie Politica, 14(1), 4550 .

Jacobs, F., \& Corbett, R. (2019). The European Parliament. Routledge.

Janeliūnas, T., \& Molis, A. (2006). Energy Security of Lithuania: Challenges and perspectives. Lithuanian political science yearbook, 200-223. 
Janušauskienè, D. (2011). Post-Communist Democratisation in Lithuania:" Elites, Parties, and Youth Political Organisations. 1988-2001" (Vol. 28). Rodopi.

Jatkauskaitè, Justina. (2013). "Influence of EU Common Energy Policy On Lithuania’s Energy Security After The Treaty Of Lisbon." Tartu.

Jastramskis M. (2014). Defeat That Was Treated for Victory: Reasons Behind the Good Performance of A. Kubilius' Government Parties in Seimas Elections. Politologija, vol. 1, no. 73, 36-66.

Jennings, W., Farrall, S., Gray, E., \& Hay, C. (2020). Moral Panics and Punctuated Equilibrium in Public Policy: An analysis of the criminal justice policy agenda in Britain. Policy Studies Journal, 48(1), 207-234.

Jensen, C. B., Proksch, S. O., \& Slapin, J. B. (2013). Parliamentary Questions, Oversight, and National Opposition Status in the European Parliament. Legislative Studies Quarterly, 38(2), 259-282.

Jochim, A. E., \& May, P. J. (2010). Beyond Subsystems: Policy regimes and governance. Policy Studies Journal, 38(2), 303-327.

Jones, M. D., \& Jenkins-Smith, H. C. (2009). Trans-subsystem Dynamics: Policy topography, mass opinion, and policy change. Policy studies journal, 37(1), 37-58.

John, P., \& Bevan, S. (2012). What are Policy Punctuations? Large changes in the legislative agenda of the UK Government, 1911-2008. Policy Studies Journal, 40(1), 89-108.

Jones, B. D., \& Baumgartner, F. R. (2012). From There to Here: Punctuated equilibrium to the general punctuation thesis to a theory of government information processing. Policy Studies Journal, 40(1), 1-20.

Jurkynas, M. (2019). Populist Parties in Lithuania: Curious case of party order and justice and its leadership. Polish Political Science Review. Polski Przegląd Politologiczny, 7(1), 120137.

Kaczorowska-Ireland, A. (2016). European Union Law. Routledge.

Kanellakis, M., Martinopoulos, G., \& Zachariadis, T. (2013). European Energy Policy A Review. Energy Policy, 62, 1020-1030.

Kirchner, E. J. (1984). The European Parliament: Performance and Prospects. Gower Publishing Company.

Kiveris, A. (2006). Ideologinių takoskyrų raiška parlamentinių Lietuvos partijų Seimo rinkimų programose 1992-2004 metais. Politikos mokslu almanachas, (02), 102-127. 
Klumbyte, N. (2014). Of Power and Laughter: Carnivalesque politics and moral citizenship in Lithuania. American Ethnologist, 41(3), 473-490.

Krupavicius, A. (2006). Lithuania. European Journal of Political Research, 45(7-8), 1166-1181.

Kingdon, J. W. (1984). Agendas, alternatives, and public policies. Little, Brown

Kuhlmann, J., \& van der Heijden, J. (2018). What is Known about Punctuated Equilibrium Theory? And what does that tell us about the construction, validation, and replication of knowledge in the policy sciences? Review of Policy Research, 35(2), 326-347.

Kosmo, M. (1987). Money to burn? The high costs of energy subsidies.

Kosti, Nir, Ilana Shpaizman, and David Levi-Faur. (2019, March 21) "The Israeli Agendas Project." Comparative Policy Agendas: Theory, Tools, Data. Oxford University Press.

Ladrech, Robert, 1996, Political Parties in the European Parliament. Political Parties and the European Union (Ed.) Gaffney, John, pp. 291-307, Routledge, London.

Langsdorf, S. (2011). EU Energy Policy: From the ECSC to the Energy Roadmap 2050. Brussels: Green European Foundation.

Leonavičius, V., Juozaitis, J., \& Genys, D. (2019). Energetinio saugumo valdysena Lietuvoje: visuomenès požiūrio ir politikos analizès palyginimas. Energetika, 65(1).

Lietuvos Respublikos Seimo rinkimai ir referendumas dèl naujos atominès elektrinès statybos Lietuvos Respublikoje (2012, October 18).

https://www.vrk.1t/statiniai/puslapiai/2012_seimo_rinkimai/output_1t/referendumas/referenduma s.html

Lithuania, Parliamentary Chamber: Seimas. Inter-Parliamentary Union. Retrieved January 8, 2021 from http://archive.ipu.org/parline-e/reports/arc/2189_92.html

Lithuanian Social Democratic Party. Istorija. Retrieved May 24, 2021 from https://www.lsdp.lt/apie/lsdp-istorija/

Lundgren, M., Squatrito, T., \& Tallberg, J. (2018). Stability and change in international policy-making: A punctuated equilibrium approach. The Review of International Organizations, 13(4), 547-572.

Malinauskas, Skirmantas. (2014). Po Rolando Pakso pirmojo atsistatydinimo ir „Wiliams“ dramos - jau 15 metų. https://www.15min.lt/naujiena/aktualu/lietuva/po-rolandopakso-pirmojo-atsistatydinimo-ir-wiliams-dramos-jau-15-metu-56-460633 
Mažylis, L., Unikaitè, I., \& Ivanovas, B. (2013). The Rise in popularity of the Lithuanian political party" Drąsos kelias". Baltic journal of law \& politics [elektroninis išteklius]. Kaunas; Berlin: Vytautas Magnus university; Walter De Gruyter, 2013, Vol. 6, no. 1.

Meyerhoff, J., Ohl, C., \& Hartje, V. (2010). Landscape externalities from onshore wind power. Energy Policy, 38(1), 82-92.

Meritet, S. (2007). French Perspectives in the Emerging European Union Energy Policy. Energy Policy, 35(10), 4767-4771.

Miliauskaite, N. (2014). Lithuania's Energy Security in the EU. Alternatives in Central Asia. GLOBEEDIT.

Mišík, M., \& Prachárová, V. (2016). Before 'Independence’ Arrived: Interdependence in energy relations between Lithuania and Russia. Geopolitics, 21(3), 579-604.

Mucciaroni, G. (1992). The garbage can model \& the study of policy making: A critique. Polity, 24(3), 459-482.

Mole, R. (2012). The Baltic States from the Soviet Union to the European Union: Identity, discourse and power in the post-communist transition of Estonia, Latvia and Lithuania. Routledge.

Molis, A., \& Vaišnoras, T. (2014). Energy Security through Membership in NATO and the EU: Interests and Achievements of Lithuania. Lithuanian foreign policy review, 32(2014), $13-32$.

Mondou, M., Skogstad, G., \& Houle, D. (2014). Policy image resilience, multidimensionality, and policy image management: A study of US biofuel policy. Journal of Public Policy, 34(1), 155-180.

Newnham, R. (2011). Oil, Carrots, and Sticks: Russia's energy resources as a foreign policy tool. Journal of Eurasian Studies, 2(2), 134-143.

European Environment Agency. (2020, November 23). The Natura 2000 Protected Areas Network 2020. https://www.eea.europa.eu/themes/biodiversity/natura-2000/the-natura-2000protected-areas-network

Nugent, N., \& Rhinard, M. (2015). The European Commission. Macmillan International Higher Education.

Olcott, M. B. (1990). The Lithuanian Crisis. Foreign Affairs, 69(3), 30-46.

Peterson, J. \& Shackleton. (2002). The Institutions of the European Union. Oxford

Polish Geological Institute. (2011). Environmental Aspects of Hydraulic Fracturing Treatment Performed on the Lebien LE-2H Well. Warsaw. 
Proksch, S. O., \& Slapin, J. B. (2011). Parliamentary Questions and Oversight in the European Union. European Journal of Political Research, 50(1), 53-79.

Puetter, U. (2014). The European Council and the Council: New intergovernmentalism and institutional change. Oxford University Press, USA.

Raunio, T. (1996). Parliamentary Questions in the European Parliament: Representation, information and control. The Journal of Legislative Studies, 2(4), 356-382.

Ramonaite, A. (2010). Voting advice applications in Lithuania: Promoting programmatic competition or breeding populism? Policy \& Internet, 2(1), 117-147

Referendum in Lithuania looks set to ratify EU membership, 2003. https://www.irishtimes.com/news/referendum-in-lithuania-looks-set-to-ratify-eu-membership$\underline{1.358629}$

Rodriguez Alex, Drukteinis, Giedrius. Lithuania's president ousted $2004<$ https://www.chicagotribune.com/news/ct-xpm-2004-04-07-0404070230-story.html

Rule 130, Rules of Procedures $2019<$ https://www.europarl.europa.eu/sides/getDoc.do?pubRef=-//EP//TEXT+RULES$\mathrm{EP}+20140701+\mathrm{RULE}-130+\mathrm{DOC}+\mathrm{XML}+\mathrm{V} 0 / / \mathrm{EN} \&$ language $=\mathrm{EN} \&$ navigationBar$=\mathrm{YES}>$

Rules of procedure for the LI Climate Justice Committee < https://liberalinternational.org/rules-of-procedure-for-the-li-climate-justice-committee/>

Sabatier A. P., and Weible M. C. (2006) “Advocacy Coalition Framework Innovations and Clarifications".

<http://edwardwimberley.com/courses/IntroEnvPol/theorypolprocess.pdf\#page=195 > 175.

Scargill, D. I. (1991). French Energy: The end of an era for coal. Geography, 76(2), 172-

Schneider, A., \& Ingram, H. (1993). Social Construction of Target Populations: Implications for politics and policy. American political science review, 87(2), 334-347.

Scully, R., Hix, S., \& Farrell, D. M. (2012). National or European Parliamentarians? Evidence from a new survey of the members of the European Parliament. JCMS: Journal of Common Market Studies, 50(4), 670-683.

Sevenans, J., \& Vliegenthart, R. (2016). Political agenda-setting in Belgium and the Netherlands: The moderating role of conflict framing. Journalism \& Mass Communication Quarterly, 93(1), 187-203.Shaffer, B. (2009). Energy Politics. University of Pennsylvania Press,. JSTOR, www.jstor.org/stable/j.ctt3fhf4v. Accessed in 31 May 2021.

Shiffman, J., Beer, T., \& Wu, Y. (2002). The emergence of global disease control priorities. Health Policy and Planning, 17(3), 225-234. 
Spinelli A. (1957) in Haines, C. G., \& Johns Hopkins University. Bologna Center. European integration. Johns Hopkins Press.

Steven, M. (2016). 'Euro-Realism' in the 2014 European Parliament Elections: The European Conservatives and Reformists (ECR) and the Democratic Deficit. Representation, 52(1), 1-12.

Svarbesnieji valstybès atstatymo 19900311 - $19921025<$

https://www.lrs.lt/datos/kovo11/ivykiai.htm> Accessed in December 20 ${ }^{\text {th }}, 2020$.

Socialist and Democrats. Our European Green Deal. Retrived May 25, 2021 from https://www.socialistsanddemocrats.eu/our-european-green-deal.

Srinivasan, T. N., \& Rethinaraj, T. G. (2013). Fukushima and thereafter: Reassessment of risks of nuclear power. Energy policy, 52, 726-736.

Sweeney, S. (2005). Europe, the State and Globalisation, Taylor \& Francis Group, ProQuest Ebook Central, https://ebookcentral.proquest.com/lib/wvu/detail.action?docID=1782368

Sytas, A. (2013, October 8) Update 1 - Chevron Quits Lithuania Shale Gas Exploration Tender. Reuters. https://www.reuters.com/article/lithuania-chevron-shalegasidCNL6N0HY3C420131008

Širinić, D., and Dario Nikić Čakar. (2019, March 21) "Croatian Political Agendas." Comparative Policy Agendas: Theory, Tools, Data. Oxford University Press.

Tamošaitis, M. (2019). Savarankiškos LKP (LDDP) dalyvavimas 1990 m. Lietuvos SSR Aukščiausiosios Tarybos ir 1992 m. Lietuvos Respublikos Seimo rinkimuose. Parliamentary Studies, (26), 69-104.

Thurber, J. A. (1991). Dynamics of Policy Subsystems in American politics. American University, Center for Congressional and Presidential Studies.

Timmermans, Arco, and Gerard Breeman. (2019, March 21) "The Dutch Policy Agendas Project." Comparative Policy Agendas: Theory, Tools, Data. Oxford University Press.

Tosun, J., \& Solorio, I. (2011). Exploring the Energy-Environment Relationship in the EU: Perspectives and challenges for theorizing and empirical analysis. European Integration Online Papers, 15(1).

Troitiño, D. R. (2017). Jean Monnet Before the First European Community: A historical perspective and critic. Trames, 21(3), 193-213.

Tumelytė, O. (2015). Tévynès Sajungos-Lietuvos krikščionių demokratu (TSLKD) ir Lietuvos socialdemokratu partijos (LSDP) 2014 m. rinkimu i Europos Parlamenta reklamines 
kampanijos integralumas: persvazijos link (Doctoral dissertation, Vytauto Didžiojo universitetas).

Ugland, T. (2011). Jean Monnet and Canada: Early travels and the Idea of European Unity. University of Toronto Press.

Vaičiūnas, Ž. (2009). Europos Sajungos bendros energetikos politikos formavimasis ir Lietuvos interesai. Politologija, (3), 89-120.

Van de Graaf, T., Haesebrouck, T., \& Debaere, P. (2018). Fractured politics? The comparative regulation of shale gas in Europe. Journal of European Public Policy, 25(9), 12761293.

Van de Graaf, T., Sovacool, B. K., Ghosh, A., Kern, F., \& Klare, M. T. (Eds.). (2016). The Palgrave Handbook of the International Political Economy of Energy (pp. 3-44). London: Palgrave Macmillan.

Vilemas, J. (2010). Energy Policy of Lithuania in 1990-2010 and Projections for the Future. International Association for Energy Economics, 39-41.

Vilpišauskas, R., Vandecasteele, B., \& Vaznonytė, A. (2013). The Lithuanian Presidency of the Council of the European Union advancing energy policy and Eastern partnership goals: conditions for exerting influence. Lithuanian Foreign Policy Review, 29, 11-37.

Vilpisauskas, R. (2014). Lithuania's EU Council Presidency: Negotiating Finances, Dealing with Geopolitics. J. Common Mkt. Stud., 52, 99.

Vilpisauskas, R. (2013). The New Member States and the European Union: Foreign Policy and Europeanization (M. Baun, D. Marek, Eds.) Taylor \& Francis Group.

Wines, M.(2002). Vilnius Journal; Is Big Brother Being Replaced by Big Oil Company? The New York Times, https://www.nytimes.com/2002/09/19/world/vilnius-journal-is-bigbrother-being-replaced-by-big-oil-company.html

Worsham, J. (1997). Other People's Money. Boulder: Westview.

Yetiv, Steve A. (2015). Myths of the Oil Boom: American National Security in a Global Energy Market, Oxford University Press, https://ebookcentral.proquest.com/lib/wvu/detail.action?doclD=1961797.

Zahariadis, N. (1999). Ambiguity, Time, and Multiple Streams. Theories of the Policy Process, 1999, 73-93. 


\section{Cited Written Parliamentary Questions}

Karl-Heinz Florenz (PPE-DE) September 29, 2006, https://www.europarl.europa.eu/doceo/document/E-6-2006-4092_EN.html?redirect

Herbert Reul (PPE) July 22, 2011, https://www.europarl.europa.eu/doceo/document/E-72011-007225_EN.html

Hans-Peter Martin (NI) November 17, 2011, https://www.europarl.europa.eu/doceo/document/E-7-2011-010563_EN.html

Willy Meyer (GUE/NGL) December 7, 2010, https://www.europarl.europa.eu/doceo/document/E-7-2010-010059_EN.html

Nuala Ahern (Verts/ALE) June 13, 2002, https://www.europarl.europa.eu/sides/getDoc.do?pubRef=-//EP//TEXT+WQ+E-2002$1707+0+\mathrm{DOC}+\mathrm{XML}+\mathrm{V} 0 / / \mathrm{EN}$

Carlos Robles Piquer (PPE) January 27, 1999, https://www.europarl.europa.eu/sides/getDoc.do?pubRef=-//EP//TEXT+WQ+E-1999$\underline{0064+0+\mathrm{DOC}+\mathrm{XML}+\mathrm{V} 0 / / \mathrm{EN}}$

W. G. van Velzen (PPE-DE) November 8, 2000, https://www.europarl.europa.eu/sides/getDoc.do?pubRef=-//EP//TEXT+WQ+P-2000$\underline{3528+0+\mathrm{DOC}+\mathrm{XML}+\mathrm{V} 0 / / \mathrm{EN}}$

Georgios Koumoutsakos (PPE) June 6, 2012, https://www.europarl.europa.eu/doceo/document/E-7-2012-005692_EN.html

Rodi Kratsa-Tsagaropoulou (PPE) April 20, 2011, https://www.europarl.europa.eu/doceo/document/E-7-2011-003868_EN.html

Giovanni Collino (PPE) April 15, 2011, https://www.europarl.europa.eu/doceo/document/E-7-2011-003789_EN.html

Jean-Pierre Audy (PPE) March 24, 2011, <

https://www.europarl.europa.eu/doceo/document/E-7-2011-002888_EN.html

Elżbieta Katarzyna Łukacijewska (PPE) July 15, 2011, https://www.europarl.europa.eu/doceo/document/E-7-2011-007013 EN.html

Vladko Todorov Panayotov (ALDE) April 11, 2011, https://www.europarl.europa.eu/doceo/document/E-7-2011-003531_EN.html

Jean-Luc Mélenchon (GUE/NGL) March 24, 2011, https://www.europarl.europa.eu/doceo/document/E-7-2011-002927_EN.html 
Mara Bizzotto (EFD) May 19, 2011, https://www.europarl.europa.eu/doceo/document/E7-2011-004892_EN.html

Dominique Vlasto (PPE) November 9, 2011, https://www.europarl.europa.eu/doceo/document/E-7-2011-010205_EN.html

Luigi de Magistris (ALDE) , Ivo Vajgl (ALDE) and Michèle Rivasi (Verts/ALE) April 4, 2011, https://www.europarl.europa.eu/doceo/document/E-7-2011-003253_EN.html

Monika Flašíková Beňová (S\&D) October 19, 2011, https://www.europarl.europa.eu/doceo/document/E-7-2011-009405_EN.html

Zbigniew Ziobro (EFD) March 8, 2013, https://www.europarl.europa.eu/doceo/document/E-7-2013-002732_EN.html

Ana Miranda (Verts/ALE) February 15, 2013, https://www.europarl.europa.eu/doceo/document/E-7-2013-001625_EN.html

Ana Miranda (Verts/ALE) May 22, 2013, https://www.europarl.europa.eu/doceo/document/E-7-2013-005746_EN.html

Willy Meyer (GUE/NGL) February 1, 2012, https://www.europarl.europa.eu/doceo/document/E-7-2012-000814_EN.html

Hiltrud Breyer (Verts/ALE) June 13, 2005, https://www.europarl.europa.eu/doceo/document/E-6-2005-2123_EN.html

Erik Meijer (GUE/NGL) February 17, 2006, https://www.europarl.europa.eu/doceo/document/E-6-2006-0617_EN.html

Agustín Díaz de Mera García Consuegra (PPE) August 19, 2010, https://www.europarl.europa.eu/doceo/document/E-7-2010-6697_EN.html

Gilles Pargneaux (S\&D) July 17, 2012, https://www.europarl.europa.eu/doceo/document/P-7-2012-007169_EN.html

Monika Flašíková Beňová (S\&D) October 15, 2013, https://www.europarl.europa.eu/doceo/document/E-7-2013-011759_EN.html

Adam Gierek (S\&D) April 11, 2012, https://www.europarl.europa.eu/doceo/document/P7-2012-003677_EN.html

Glenis Willmott (PSE) April 30, 2007, https://www.europarl.europa.eu/doceo/document/E-6-2007-2300_EN.html 
Alonso Puerta (GUE/NGL), Laura González Álvarez (GUE/NGL), Ludivina García Arias (PSE) and Fernando Morán López (PSE) January 30, 1998, https://www.europarl.europa.eu/sides/getDoc.do?pubRef=-//EP//TEXT+WQ+E-1998$\underline{0119+0+\mathrm{DOC}+\mathrm{XML}+\mathrm{V} 0 / / \mathrm{EN} \& \text { language }=\mathrm{EN}}$

Alyn Smith (Verts/ALE) February 8, 2007,

https://www.europarl.europa.eu/doceo/document/E-6-2007-0465_EN.html

Ashley Mote (NI) February 3, 2009, https://www.europarl.europa.eu/doceo/document/E6-2009-0481_EN.html

Oreste Rossi (EFD) October 17, 2011, https://www.europarl.europa.eu/doceo/document/E-7-2011-009318_EN.html

Mara Bizzotto (EFD) July 12, 2011, https://www.europarl.europa.eu/doceo/document/E7-2011-006871_EN.html

Michał Tomasz Kamiński (ECR) June 30, 2010, https://www.europarl.europa.eu/doceo/document/E-7-2010-4855_EN.html

Juozas Imbrasas (EFD) April 23, 2014, https://www.europarl.europa.eu/doceo/document/E-7-2014-005401_EN.html

Angelika Werthmann (NI) March 15, 2012, https://www.europarl.europa.eu/doceo/document/E-7-2012-002879_EN.html

Kathleen Van Brempt (S\&D) July 7, 2011, https://www.europarl.europa.eu/doceo/document/E-7-2011-006509_EN.html

Dominique Vlasto (PPE) November 9, 2011, https://www.europarl.europa.eu/doceo/document/E-7-2011-010205_EN.html

Oreste Rossi (EFD) May 31, 2011, <https://www.europarl.europa.eu/doceo/document/E7-2011-005306_EN.html>

Nuno Melo (PPE) May 17, 2010, <https://www.europarl.europa.eu/doceo/document/E-72010-3528_EN.html

Georgios Toussas (GUE/NGL) December 5, 2011, https://www.europarl.europa.eu/doceo/document/E-7-2011-011046_EN.html

Michail Tremopoulos (Verts/ALE) March 4, 2011, https://www.europarl.europa.eu/doceo/document/E-7-2011-001881_EN.html 
Alexandros Alavanos (GUE/NGL) May 28, 2001, <https://www.europarl.europa.eu/sides/getDoc.do?pubRef=-//EP//TEXT+WQ+E-2001$\underline{1551+0+\mathrm{DOC}+\mathrm{XML}+\mathrm{V} 0 / / \mathrm{EN} \& \text { language }=\mathrm{EN}}$

Patricia McKenna (Verts/ALE) March 02, 2004, https://www.europarl.europa.eu/sides/getDoc.do?pubRef=-//EP//TEXT+WQ+E-2004$\underline{0795+0+\mathrm{DOC}+\mathrm{XML}+\mathrm{V} 0 / / \mathrm{EN} \& \text { language }=\mathrm{EN}}$

Auke Zijlstra (NI) October 27, 2011, https://www.europarl.europa.eu/doceo/document/E-7-2011-009754_EN.html.

Auke Zijlstra (NI) and Lucas Hartong (NI) September 6, 2012, https://www.europarl.europa.eu/doceo/document/E-7-2012-007899_EN.html.

Tomasz Piotr Poręba (ECR) April 11, 2012, https://www.europarl.europa.eu/doceo/document/P-7-2012-003680_EN.html.

Zbigniew Ziobro (EFD) February 18, 2013, https://www.europarl.europa.eu/doceo/document/E-7-2013-001670_EN.html.

Oreste Rossi (EFD) September 28, 2010, https://www.europarl.europa.eu/doceo/document/E-7-2010-7626_EN.html

Morten Messerschmidt (EFD) April 7, 2010, https://www.europarl.europa.eu/doceo/document/E-7-2010-2143_EN.html

Licia Ronzulli (PPE) April 20, 2011, https://www.europarl.europa.eu/doceo/document/E7-2011-003940_EN.html

Sergio Paolo Frances Silvestris (PPE) January 25, 2012, https://www.europarl.europa.eu/doceo/document/E-7-2012-000213 EN.html

Marc Tarabella (S\&D) November 21, 2012, https://www.europarl.europa.eu/doceo/document/E-7-2012-010653_EN.html

Monika Flašíková Beňová (S\&D) January 10, 2013, https://www.europarl.europa.eu/doceo/document/E-7-2013-000220_EN.html

Zigmantas Balčytis (S\&D) May 30, 2013, https://www.europarl.europa.eu/doceo/document/E-7-2013-006124_EN.html

Kathleen Van Brempt (S\&D) October 2, 2013, https://www.europarl.europa.eu/doceo/document/E-7-2013-011198_EN.html?redirect 


\section{Cited Lithuanian Laws}

XI-802 - Lietuvos Respublikos darbuotojų saugos ir sveikatos ịstatymo 8, 12, 13, 22, 27 straipsnių pakeitimo ir 12-1 straipsnio pripažinimo netekusiu galios ịstatymas. https://eseimas.lrs.lt/portal//egalAct/lt/TAD/TAIS.373032

I-1324 - Lietuvos Respublikos potencialiai pavojingų ịrenginių priežiūros įstatymas. https://e-seimas.lrs.lt/portal/legalAct/lt/TAD/TAIS.27535?.jfwid=rivwzvpvg

I-774 - Dėl Lietuvos Respublikos pridètinès vertès mokesčio ịstatymo pakeitimo ir papildymo. https://e-seimas.lrs.lt/portal/legalAct/lt/TAD/TAIS.15206

I-828 - Lietuvos Respublikos energetikos įstatymas. https://eseimas.lrs.lt/portal/legalAct/lt/TAD/TAIS.16637?positionInSearchResults=71\&searchModelUUI $\mathrm{D}=\mathrm{d} 1 \mathrm{acd} 1 \mathrm{fc}-\mathrm{c} 751-401 \mathrm{f}-8735-3 \mathrm{df0ae} 85 \mathrm{ce} 61$

VIII-1443 - Lietuvos Respublikos valstybės ir tarnybos paslapčių ịstatymas. https://eseimas.lrs.lt/portal/legalAct/lt/TAD/TAIS.91654/asr

VIII-971 - Lietuvos Respublikos civilinès saugos ịstatymas. https://eseimas.lrs.lt/portal/legalAct/lt/TAD/TAIS.69957/asr

VIII-1661 - Lietuvos Respublikos Ignalinos atominès elektrinès eksploatavimo nutraukimo įstatymas. https://e-seimas.lrs.lt/portal/legalAct/lt/TAD/TAIS.101060/asr

VIII-1210 - Lietuvos Respublikos viešojo pirkimo ịstatymo pakeitimo ịstatymas. https://e-seimas.lrs.lt/portal/legalAct/lt/TAD/TAIS.82787

IX-466 - Lietuvos Respublikos valstybès įmonès Ignalinos atominès elektrinès eksploatavimo nutraukimo fondo ịstatymas. https://eseimas.lrs.lt/portal/legalAct/lt/TAD/TAIS.145532?jfwid=i3h7ws9ck

IX-2550 - Lietuvos Respublikos 2005 metų valstybės biudžeto ir savivaldybių biudžetų finansinių rodiklių patvirtinimo ịstatymas. https://eseimas.lrs.lt/portal/legalAct/lt/TAD/TAIS.245870/LDFXXDYlTx

IX-586 - Lietuvos Respublikos branduolinès energijos ịstatymo 16 ir 32 straipsniu pakeitimo ịstatymas. https://e-seimas.lrs.lt/portal/legalAct/lt/TAD/TAIS.154662

IX-1132 - Lietuvos Respublikos nacionaliniam saugumui užtikrinti svarbių objektų apsaugos ịstatymas. https://e-

seimas.lrs.lt/portal/legalAct/lt/TAD/TAIS.189498?jfwid=oou0hj98m

IX-1417 - Lietuvos Respublikos branduolinės energijos ịstatymo 2, 22 ir 51 straipsnių pakeitimo ịstatymas. https://e-seimas.lrs.lt/portal/legalAct/lt/TAD/TAIS.209614 
IX-2505 - Lietuvos Respublikos branduolinès energijos ịstatymo 21 straipsnio pakeitimo istatymas. https://e-seimas.lrs.lt/portal/legalAct/lt/TAD/TAIS.244679

IX-884 - Lietuvos Respublikos energetikos ịstatymas. https://eseimas.lrs.lt/portal/legalAct/lt/TAD/TAIS.167899?jfwid=rivwzvpvg\%2Fasr

IX-628 - Lietuvos Respublikos saugomų teritorijų ịstatymo pakeitimo įstatymas. https://e-seimas.lrs.lt/portal/legalAct/lt/TAD/TAIS.156931

X-258 - Lietuvos Respublikos planuojamos ūkinès veiklos poveikio aplinkai vertinimo istatymo pakeitimo ịstatymas. https://e-seimas.lrs.lt/portal/legalAct/lt/TAD/TAIS.259244

X-471 - Lietuvos Respublikos viešujų pirkimų isstatymo pakeitimo ịstatymas. https://eseimas.lrs.lt/portal/legalAct/lt/TAD/TAIS.268778

X-202 - Lietuvos Respublikos valstybės įmonės Ignalinos atominės elektrinės pirmojo bloko eksploatavimo nutraukimo ịstatymo 4 ir 10 straipsnių pakeitimo įstatymas. https://eseimas.lrs.lt/portal//egalAct/lt/TAD/TAIS.256792

X-254 - Lietuvos Respublikos valstybės įmonės Ignalinos atominės elektrinės darbuotojų papildomų užimtumo ir socialinių garantijų i̇statymo 5 ir 9 straipsnių pakeitimo įstatymas. https://e-seimas.lrs.lt/portal/legalAct/lt/TAD/TAIS.258285

X-741 - Lietuvos Respublikos 2006 metų valstybès biudžeto ir savivaldybių biudžetu finansinių rodiklių patvirtinimo ịstatymo pakeitimo ir papildymo ịstatymas. https://eseimas.lrs.lt/portal/legalAct/lt/TAD/TAIS.280127

X-258 - Lietuvos Respublikos planuojamos ūkinès veiklos poveikio aplinkai vertinimo istatymo pakeitimo įstatymas. https://e-seimas.lrs.lt/portal/legalAct/lt/TAD/TAIS.259244

XI-329 - Lietuvos Respublikos klimato kaitos valdymo finansinių instrumentų įstatymas. https://e-seimas.lrs.lt/portal/legalActEditions/lt/TAD/TAIS.349514

XI-619 - Lietuvos Respublikos teritorijų planavimo ịstatymo 2, 4, 15, 19, 20, 21, 22, 23, 24, 26, 31, 37 straipsnių pakeitimo ir papildymo ịstatymas. https://eseimas.lrs.lt/portal/legalAct/lt/TAD/TAIS.362024

XI-1375 - Lietuvos Respublikos atsinaujinančiu išteklių energetikos ịstatymas. https://eseimas.lrs.lt/portal/legalAct/lt/TAD/TAIS.398874

XI-2084 - Lietuvos Respublikos atominès elektrinès ịstatymo pakeitimo ịstatymas. https://e-seimas.lrs.lt/portal/legalAct/lt/TAD/TAIS.428228

XI-2052 - Lietuvos Respublikos elektros energetikos sistemos sujungimo su kontinentinès Europos elektros tinklais darbui sinchroniniu režimu ịstatymas. https://eseimas.lrs.lt/portal/legalAct/lt/TAD/TAIS.427220?jfwid=-oleo6wbvx 
XII-737 - Lietuvos Respublikos valstybès įmonès Ignalinos atominès elektrinès eksploatavimo nutraukimo fondo ịstatymo 2, 3, 4, 5 straipsnių pakeitimo ir papildymo įstatymas. https://e-seimas.lrs.lt/portal/legalAct/lt/TAD/TAIS.463449?jfwid=-7dy01k18t

XII-2504 - Lietuvos Respublikos valstybès įmonès Ignalinos atominès elektrinès darbuotojų papildomų užimtumo ir socialinių garantijų įstatymo Nr. IX-1541 2, 4, 5, 8 straipsnių pakeitimo ir 7 straipsnio pripažinimo netekusiu galios įstatymas. https://eseimas.lrs.1t/portal/legalAct/lt/TAD/c7231d003ec711e68f278e2f1841c088

XII-2702 - Lietuvos Respublikos energijos vartojimo efektyvumo didinimo įstatymas. https://e-seimas.lrs.1t/portal/legalAct/lt/TAD/1bd85ba0a27b11e68987e8320e9a5185?jf$\underline{\text { wid=wny8rgfbk }}$

XII-2190 - Lietuvos Respublikos radiacinès saugos įstatymo Nr. VIII-1019 2, 6, 7, 7-1, 8, 8-3, 8-4, 10, 11, 15, 21, 23 straipsnių pakeitimo, İstatymo papildymo 8-5, 8-6, 15-1 straipsniais ir 8-1, 8-2 straipsnių pripažinimo netekusiais galios įstatymas. https://eseimas.1rs.1t/portal/legalAct/lt/TAD/52ff4d80a7c411e59010bea026bdb259

XII-2128 - Lietuvos Respublikos akcizų ịstatymo Nr. IX-569 1, 2, 48, 53, 57, 58, 58-1, 59, 60 straipsnių ir İstatymo 1 priedo pakeitimo įstatymas. https://eseimas.1rs.1t/portal/legalAct/lt/TAD/6239c2d09a7211e58856802eb9fdffa1

XII-1483 - Lietuvos Respublikos klimato kaitos valdymo finansinių instrumentų įstatymo Nr. XI-329 2, 5, 6, 8, 12-1, 13, 15, 18 ir 20 straipsnių, 1 ir 2 priedų pakeitimo ịstatymas. https://e-seimas.lrs.lt/portal/legalAct/lt/TAD/a831bf408a6511e4be90fee65c21bf37

XII-169 - Lietuvos Respublikos atsinaujinančių išteklių energetikos įstatymo 2, 11, 13, 14, 16, 20, 21 straipsnių pakeitimo ir papildymo ịstatymas. https://eseimas.Irs.1t/portal/legalAct/lt/TAD/TAIS.441937

XII-170 - Lietuvos Respublikos atsinaujinančių išteklių energetikos įstatymo 2, 11, 13, 14, 16, 20, 21 straipsnių pakeitimo ir papildymo ịstatymo igyvendinimo ịstatymas. https://eseimas.lrs.lt/portal/legalAct/lt/TAD/TAIS.441938

XII-1389 - Lietuvos Respublikos atsinaujinančių išteklių energetikos įstatymo Nr. XI137520 straipsnio pakeitimo įstatymas. https://eseimas.1rs.1t/portal/legalAct/lt/TAD/5e647d908a2311e4be90fee65c21bf37

XII-1666 - Lietuvos Respublikos atsinaujinančių išteklių energetikos įstatymo Nr. XI1375 6, 13, 14, 15, 16 ir 22 straipsnių pakeitimo ịstatymas. https://eseimas.1rs.1t/portal/legalAct/lt/TAD/cbddc672fa3411e4877aa4fe9d0c24b0

XII-847 - Lietuvos Respublikos atsinaujinančių išteklių energetikos įstatymo Nr. XI-1375 49 ir 51 straipsniu pakeitimo ịstatymas. https://eseimas.lrs.1t/portal/legalAct/lt/TAD/b31247d2cc7011e39b2ab5bbcc4f49fb 
XII-352 - Lietuvos Respublikos žemės gelmių ịstatymo 1, 2, 3, 4, 5, 6, 8, 9, 11, 12, 13, $14,15,18,19,21,22,27$ straipsnių pakeitimo ir papildymo ir İstatymo papildymo 6-1 straipsniu istatymas. https://e-seimas.lrs.1t/portal/legalAct/lt/TAD/TAIS.450336?jfwid=-8ynj5gpaz

XII-353 - Lietuvos Respublikos planuojamos ūkinès veiklos poveikio aplinkai vertinimo istatymo 1 priedo papildymo įstatymas. https://e-

seimas.lrs.lt/portal/legalAct/lt/TAD/TAIS.450340

XII-1786 - Lietuvos Respublikos žemės gelmių įstatymo Nr. I-1034 22 straipsnio pakeitimo istatymas. https://e-

seimas.1rs.1t/portal/legalAct/lt/TAD/dc088f70135311e5af81c7d24921dbde 